\title{
AGR-2 As-Irradiated UCO Compact 5-4-2 PIE Report
}

Approved for public release. Distribution is unlimited
John D. Hunn

Tyler J. Gerczak

Fred C. Montgomery

Darren J. Skitt

Charles A. Baldwin Grant W. Helmreich

Brian D. Eckhart John A. Dyer

May 2018 


\section{DOCUMENT AVAILABILITY}

Reports produced after January 1, 1996, are generally available free via US Department of Energy (DOE) SciTech Connect.

Website http://www.osti.gov/scitech/

Reports produced before January 1, 1996, may be purchased by members of the public from the following source:

National Technical Information Service

5285 Port Royal Road

Springfield, VA 22161

Telephone 703-605-6000 (1-800-553-6847)

TDD 703-487-4639

Fax 703-605-6900

E-mail info@ntis.gov

Website http://www.ntis.gov/help/ordermethods.aspx

Reports are available to DOE employees, DOE contractors, Energy Technology Data Exchange representatives, and International Nuclear Information System representatives from the following source:

Office of Scientific and Technical Information

PO Box 62

Oak Ridge, TN 37831

Telephone 865-576-8401

Fax 865-576-5728

E-mail reports@osti.gov

Website http://www.osti.gov/contact.html

This report was prepared as an account of work sponsored by an agency of the United States Government. Neither the United States Government nor any agency thereof, nor any of their employees, makes any warranty, express or implied, or assumes any legal liability or responsibility for the accuracy, completeness, or usefulness of any information, apparatus, product, or process disclosed, or represents that its use would not infringe privately owned rights. Reference herein to any specific commercial product, process, or service by trade name, trademark, manufacturer, or otherwise, does not necessarily constitute or imply its endorsement, recommendation, or favoring by the United States Government or any agency thereof. The views and opinions of authors expressed herein do not necessarily state or reflect those of the United States Government or any agency thereof. 
Fusion and Materials for Nuclear Systems Division

\section{AGR-2 AS-IRRADIATED UCO COMPACT 5-4-2 PIE REPORT \\ Evaluation of As-Irradiated Fuel Performance with Leach-Burn-Leach, IMGA, X-ray Tomography, and Materialography}

John D. Hunn

Tyler J. Gerczak

Fred C. Montgomery

Darren J. Skitt

Charles A. Baldwin

Grant W. Helmreich

Brian D. Eckhart

John A. Dyer

Date Published: May 2018

Work sponsored by

US DEPARTMENT OF ENERGY

Office of Nuclear Energy - Advanced Reactor Technologies

under the

Advanced Gas Reactor Fuel Development and Qualification Program

Prepared by

OAK RIDGE NATIONAL LABORATORY

Oak Ridge, TN 37831-6283

managed by

UT-BATTELLE, LLC

for the

US DEPARTMENT OF ENERGY

under contract DE-AC05-00OR22725 



\section{CONTENTS}

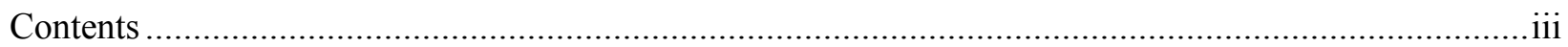

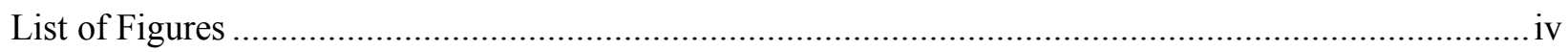

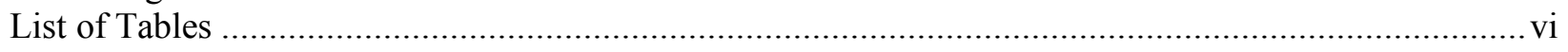

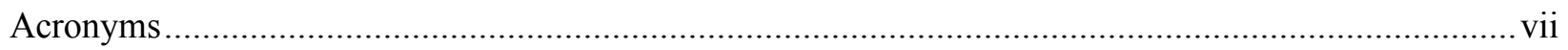

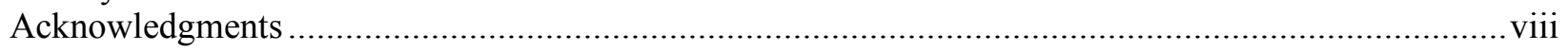

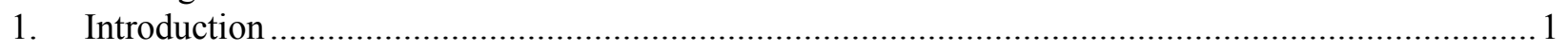

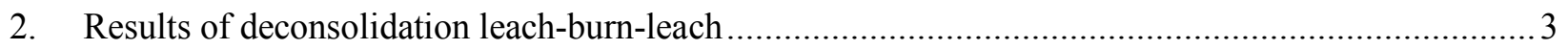

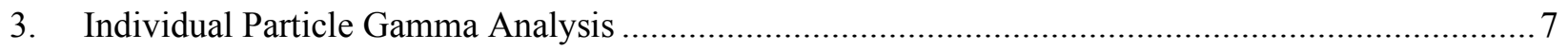

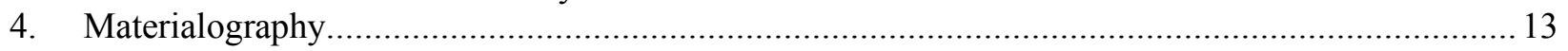

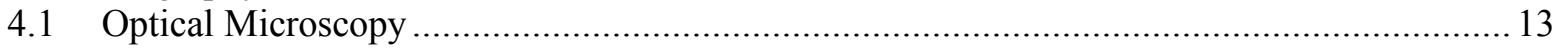

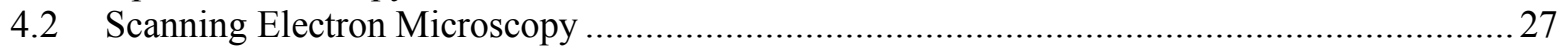

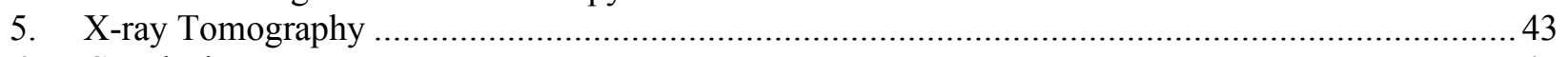

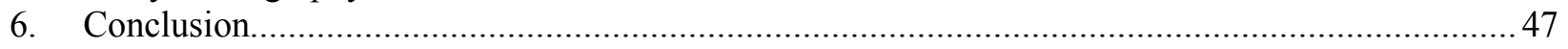

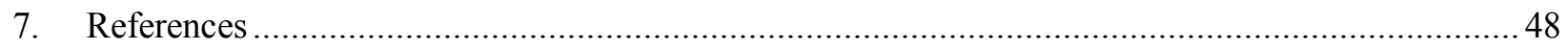




\section{LIST OF FIGURES}

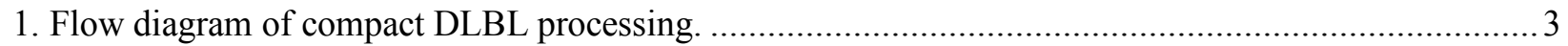

2. Particle distribution for measured ${ }^{144} \mathrm{Ce}$ activity, normalized to the average. ................................... 7

3. Particle distribution for measured ${ }^{137} \mathrm{Cs}$ activity, normalized to the average. .................................. 8

4. Ratio of ${ }^{137} \mathrm{Cs}$ retained in 3190 particles versus the calculated inventory, adjusted for variation in fissionable material and burnup with the measured ${ }^{144} \mathrm{Ce}$ activity. ......................... 8

5. Ratio of ${ }^{110 \mathrm{~m}} \mathrm{Ag}$ retained in 44 particles versus the calculated inventory, adjusted for variation in fissionable material and burnup with the measured ${ }^{137} \mathrm{Cs}$ activity.

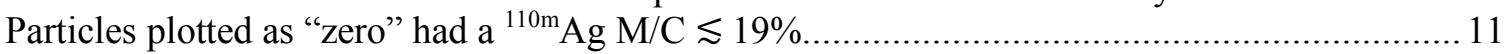

6. Ratio of ${ }^{144} \mathrm{Ce}$ retained in 44 particles versus the calculated inventory, adjusted for variation in fissionable material and burnup with the measured ${ }^{137} \mathrm{Cs}$ activity........................... 12

7. Ratio of ${ }^{154} \mathrm{Eu}$ retained in 44 particles versus the calculated inventory, adjusted for variation in fissionable material and burnup with the measured ${ }^{137} \mathrm{Cs}$ activity.......................... 12

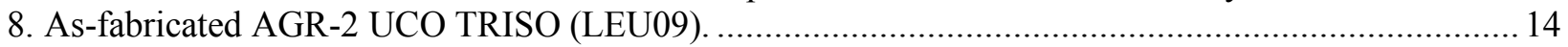

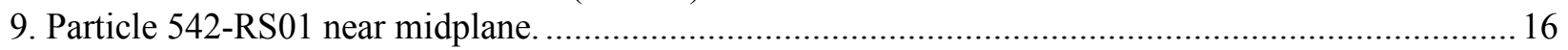

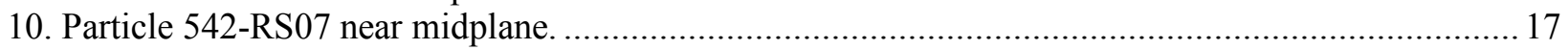

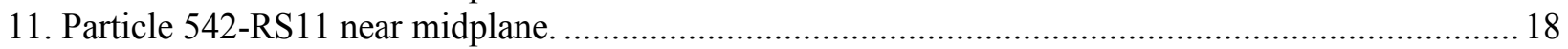

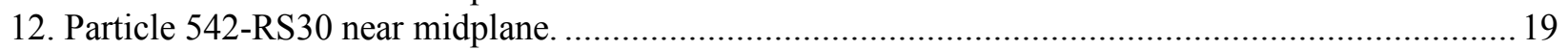

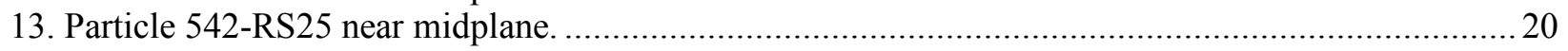

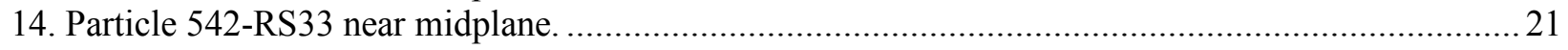

15. Images of randomly-selected particles from multiparticle mount MM-E07.................................22

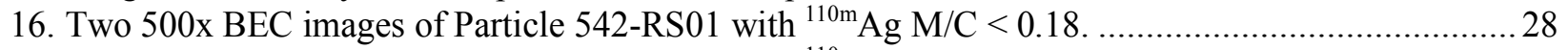

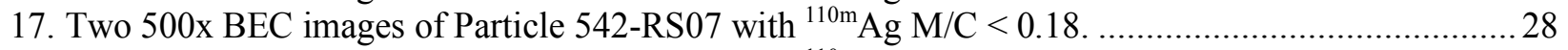

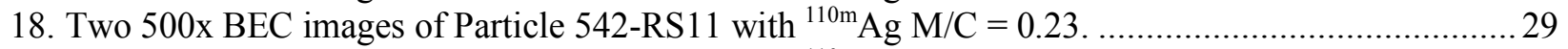

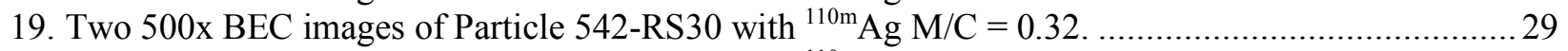

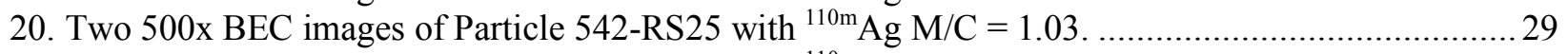

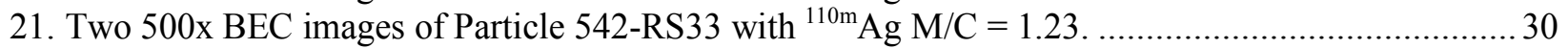

22. Comparision of SE and BEC image pairs of lowest-silver Particle 542-RS01

$\left({ }^{110 \mathrm{~m}} \mathrm{Ag} \mathrm{M} / \mathrm{C}<0.18\right)$ showing embedded high-Z features across SiC layer and

differentiation of surface debris from embedded high- $Z$ features.

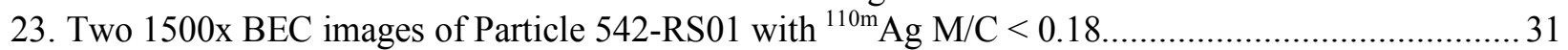

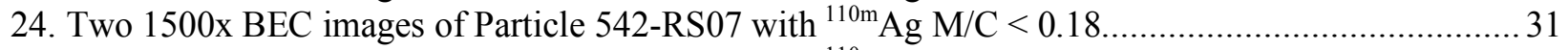

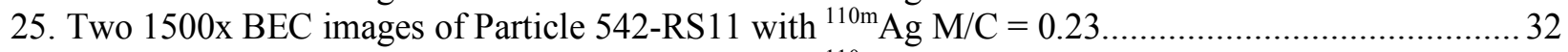

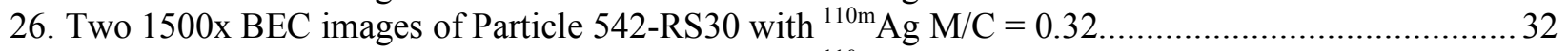

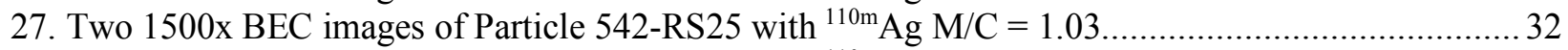

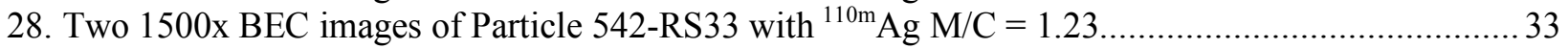

29. Pd-only and Pd-U features in the SiC layer of lowest-silver Particle 542-RS07

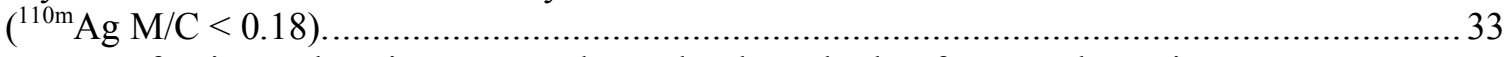

30 EDS spectra of Point-ID locations centered on Pd-only and Pd-U features shown in

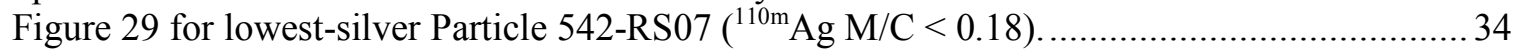

31. Pd-U features at the IPyC/SiC interface and in a micron-scale pileup features (large feature) in the IPyC layer of lowest-silver Particle 542-RS01 ( $\left.{ }^{110 \mathrm{~m}} \mathrm{Ag} \mathrm{M} / \mathrm{C}<0.18\right)$.................. 34

32. EDS spectra of Point-ID locations centered on $\mathrm{Pd}-\mathrm{U}$ features shown in Figure 31 for

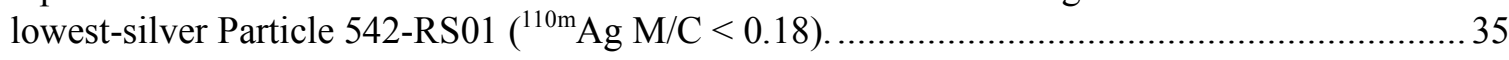

33. Pd-U, Pd-only, and $\mathrm{Pd}-\mathrm{U}-\mathrm{Zr}$ feature at the IPyC/SiC interface of lowest-silver Particle 542-RS07 $\left({ }^{110 \mathrm{~m}} \mathrm{Ag} \mathrm{M} / \mathrm{C}<0.18\right)$..

34. EDS spectra of Point-ID locations centered on Pd-U, Pd-only, and Pd-U-Zr features shown in Figure 33 for lowest-silver Particle 542-RS07 ( $\left.{ }^{110 \mathrm{~m}} \mathrm{Ag} \mathrm{M} / \mathrm{C}<0.18\right)$.......................... 36

35. Example of a Pd-only feature in the SiC layer of low-silver Particle 542-RS30 $\left({ }^{110 \mathrm{~m}} \mathrm{Ag} \mathrm{M} / \mathrm{C}=0.32\right)$...

36. EDS spectra of Point-ID location centered on Pd-only feature shown in Figure 35 for low-silver Particle 542-RS30 $\left({ }^{110 \mathrm{~m}} \mathrm{Ag} \mathrm{M} / \mathrm{C}=0.32\right)$. 
37. Pd-only feature at the $\mathrm{IPyC} / \mathrm{SiC}$ interface and in a micron-scale pileup feature (large feature) near the IPyC/SiC interface of low-silver Particle 542-RS11 $\left({ }^{110 \mathrm{~m}} \mathrm{Ag} \mathrm{M} / \mathrm{C}=0.23\right)$.

38. EDS spectra of Point-ID locations centered on Pd-only features shown in Figure 37

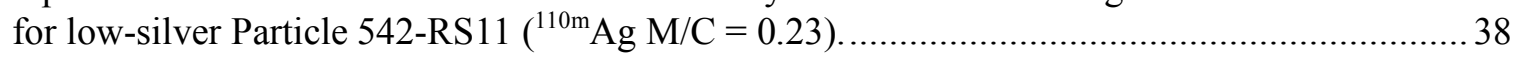

39. Pd-only features at the IPyC/SiC interface of high-silver Particle 542-RS25 $\left({ }^{110 \mathrm{~m}} \mathrm{Ag} \mathrm{M} / \mathrm{C}=1.03\right)$.. .38

40. EDS spectra of Point-ID locations centered on Pd-only features shown in Figure 39 for high-silver Particle 542-RS25 $\left({ }^{110 \mathrm{~m}} \mathrm{Ag} \mathrm{M} / \mathrm{C}=1.03\right)$.

41. Probable debris at the SiC/OPyC interface in lowest-silver Particle 542-RS01 $\left({ }^{110 \mathrm{~m}} \mathrm{Ag} \mathrm{M} / \mathrm{C}<0.18\right)$.

42. EDS spectra of Point-ID location centered on probable debris shown in Figure 41 for lowest-silver Particle 542-RS01 ( $\left.{ }^{110 \mathrm{~m}} \mathrm{Ag} \mathrm{M} / \mathrm{C}<0.18\right)$.

43. Point-ID analysis locations near buffer/kernel interface in Particle 542-RS01.

44. EDS spectra of Point-ID locations marked in Figure 43 of Particle 542-RS01

45. Point-ID analysis locations in Particle 542-RS01 surrounding area that showed buffer-colored material inside the kernel (Figure 9).

46. EDS spectra of Point-ID locations marked in Figure 45 of Particle 542-RS01.............................. 42

47. Orthogonal oblique tomograms through center of Particle 542-RS05 ..........................................4 44

48. Orthogonal oblique tomograms through center of Particle 542-RS32 ........................................ 45

49. Orthogonal oblique tomograms through center of Particle 542-RS13 ........................................... 46 


\section{LIST OF TABLES}

1. Irradiation conditions for AGR-2 UCO Compact 5-4-2 ….................................................... 2

2. Exposed compact inventory fractions ${ }^{a}$ of $\mathrm{U}$ and $\mathrm{Pu}$ detected by DLBL ...................................... 4

3. Exposed compact inventory fractions ${ }^{a}$ of typically-tracked beta/gamma-emitting

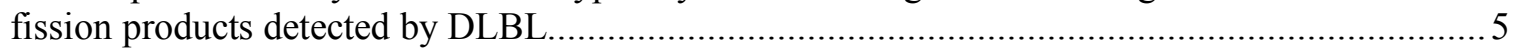

4. Exposed compact inventory fractions ${ }^{a}$ of stable isotopes of interest detected by DLBL ..................... 6

5. Results from 4-hour gamma scanning of 44 randomly-selected (RS) particles showing measured activity in $\mathrm{Bq} /$ particle decay-corrected to $\mathrm{EOL}+1$ day .......................................... 9

6. Summary of results from 4-hour IMGA analysis of Compact 5-4-2 particles ................................. 11

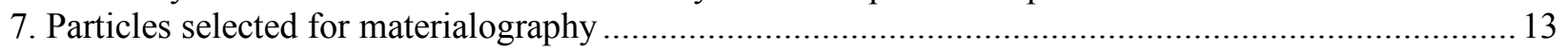

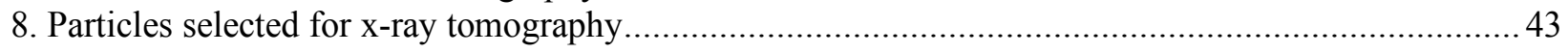




\section{ACRONYMS}

AGR Advanced Gas Reactor (Fuel Development and Qualification Program)

AGR-1

AGR-2

ATR

BEC

BWXT-NOG

$\mathrm{CO}$

DLBL

EDS

FIMA

ID

IFEL

IMGA

INL

$\mathrm{M} / \mathrm{C}$

OPyC

ORNL

PGS

PIE

SE

SEM

$\mathrm{SiC}$

$\mathrm{TA}_{\text {min }}$

$\mathrm{TA}_{\max }$

TAVA

TRISO

UCO

$\mathrm{UO}_{2}$

$\mathrm{Z}$
First AGR program irradiation experiment

Second AGR program irradiation experiment

Advanced Test Reactor

Backscattered-electron composition

BWX Technologies Nuclear Operations Group

Carbon monoxide

Deconsolidation leach-burn-leach

Energy-dispersive x-ray spectroscopy

Fissions per initial metal atom

Identification

Irradiated Fuels Examination Laboratory (hot cells)

Irradiated Microsphere Gamma Analyzer

Idaho National Laboratory

Measured versus calculated isotopic activity (adjusted for fissile inventory and burnup)

Outer pyrolytic carbon (TRISO layer)

Oak Ridge National Laboratory

Precision Gamma Scanner

Post-irradiation examination

Secondary electron

Scanning electron microscope

Silicon carbide (TRISO layer)

Time-averaged minimum temperature

Time-averaged maximum temperature

Time-averaged/volume-averaged temperature

Tristructural-isotropic (coated particles)

Uranium carbide/uranium oxide mixture (fuel kernels)

Uranium dioxide (fuel kernels)

Atomic number 


\section{ACKNOWLEDGMENTS}

This work was sponsored by the U.S. Department of Energy, Office of Nuclear Energy, through the Idaho National Laboratory Advanced Reactor Technologies Technology Development Office as part of the Advanced Gas Reactor Fuel Development and Qualification Program. Analysis of leach solutions was provided by the Oak Ridge National Laboratory Nuclear Analytical Chemistry \& Isotopics Laboratory. Hot cell activities were supported by the staff of the Oak Ridge National Laboratory Irradiated Fuels Examination Laboratory (IFEL). 


\section{INTRODUCTION}

As discussed in a previous report [Hunn et al. 2016] and reproduced in the following three paragraphs to provide background information and common terminology, post-irradiation examination (PIE) is being performed on tristructural-isotropic (TRISO) coated-particle fuel compacts from the Advanced Gas Reactor (AGR) Fuel Development and Qualification Program second irradiation experiment (AGR-2) [Collin 2014]. This effort builds upon the understanding acquired throughout the AGR-1 PIE campaign [Demkowicz et al. 2015] and is establishing a database for the different AGR-2 fuel designs.

The AGR-2 irradiation experiment included TRISO fuel particles coated at BWX Technologies Nuclear Operations Group (BWXT-NOG) with a 150-mm-diameter engineering-scale coater. Two coating batches were tested in the AGR-2 irradiation experiment. Batch 93085 had 508- $\mu$ m-diameter uranium dioxide $\left(\mathrm{UO}_{2}\right)$ kernels. Batch 93073 had $427-\mu \mathrm{m}$-diameter UCO kernels, which is a kernel design where some of the uranium oxide is converted to uranium carbide during fabrication to provide a getter for oxygen liberated during fission and limit CO production. Fabrication and property data for the AGR-2 coating batches have been compiled [Barnes and Marshall 2009] and compared to AGR-1 [Phillips, Barnes, and Hunn 2010]. The AGR-2 TRISO coatings were most like the AGR-1 Variant 3 TRISO deposited in the 50-mm-diameter Oak Ridge National Laboratory (ORNL) lab-scale coater [Hunn and Lowden 2006]. In both cases argon-dilution of the hydrogen and methyltrichlorosilane coating gas mixture employed to deposit the $\mathrm{SiC}$ was used to produce a finer-grain, more equiaxed $\mathrm{SiC}$ microstructure [Lowden 2006; Gerczak et al. 2016]. In addition to the fact that AGR-1 fuel had smaller, 350- $\mu$ m-diameter UCO kernels, notable differences in the TRISO particle properties included the pyrocarbon anisotropy, which was slightly higher in the particles coated in the engineering-scale coater, and the exposed kernel defect fraction, which was higher for AGR-2 fuel due to the detected presence of particles with impact damage introduced during TRISO particle handling [Hunn 2010].

Irradiation test compacts containing AGR-2 fuel particles were compacted at ORNL with the same resinated-graphite blend used to make AGR-1 compacts and a modified pressing process that utilized a die heated to $65^{\circ} \mathrm{C}$ and a new computer-controlled servo-press. Two compact lots were produced and qualified for the AGR-2 irradiation test: Lot LEU09-OP2-Z contained the UCO TRISO particles [Hunn, Montgomery, and Pappano 2010a] and Lot LEU11-OP2-Z contained the $\mathrm{UO}_{2}$ fuel [Hunn, Montgomery, and Pappano 2010b]. Compared to the AGR-1 compacts, which were compacted at room temperature using a manual press, the modified AGR-2 compacting process produced compacts with reduced variability in length and higher matrix density $\left(1.6-1.7 \mathrm{~g} / \mathrm{cm}^{3}\right.$ for AGR-2 compacts versus $1.2-1.3 \mathrm{~g} / \mathrm{cm}^{3}$ for AGR-1 compacts). Compilations of the properties data for the particles and compacts are available in pre-irradiation characterization summary reports for the AGR-1 [Hunn, Savage, and Silva 2012] and AGR-2 [Hunn, Savage, and Silva 2010] fuel composites.

The AGR-2 Post-Irradiation Examination Plan [Demkowicz 2013] includes shipment of irradiated compacts from the Idaho National Laboratory (INL) to the ORNL for destructive PIE in both the asirradiated condition and after safety testing. This PIE includes deconsolidation leach-burn-leach (DLBL) analysis for exposed fission products, "gamma results from short-counting time gamma surveys performed on all the recovered TRISO particles with the ORNL Irradiated Gamma Microsphere Analyzer (IMGA), results from long-counting time IMGA measurements performed on specially-selected particles that exhibited significant cesium release or other unusual radioisotopic release, and similar IMGA measurements performed on 40-60 randomly-selected particles. Microstructural analysis using X-ray microtomography and materialographic methods are performed to investigate radiation-induced changes in the particles and elucidate the mechanisms responsible for observed fission product release. Materialographic methods typically include mechanical polishing of particle cross section, imaging with

\footnotetext{
* In this report, the term "fission product" is used in a general sense to refer to all the post-fission isotopes remaining at the end of the irradiation test. These include: isotopes directly generated by the fission process, isotopes generated by neutron activation, isotopes generated by radioactive decay, and residual uranium.
} 
an optical microscope, imaging with a scanning electron microscope (SEM), and atomic analysis via energy-dispersive x-ray spectroscopy (EDS).

In this report, results from PIE of as-irradiated AGR-2 UCO Compact 5-4-2 are reported. Compact 5-4-2 was irradiated in the INL Advanced Test Reactor (ATR). Table 1 shows the calculated burnup in percent fissions per initial metal atom (FIMA), the fast neutron fluence (neutron energies $>0.18 \mathrm{MeV}$ ), and calculated compact temperatures during irradiation.

Table 1. Irradiation conditions for AGR-2 UCO Compact 5-4-2

\begin{tabular}{cccccccc}
\hline \multirow{2}{*}{ Compact ID $^{a}$} & Fabrication ID $^{b}$ & Fuel Type & $\begin{array}{c}\text { Average Burnup }^{c} \\
\text { (FIMA) }\end{array}$ & $\begin{array}{c}\text { Fast Fluence }^{c} \\
(\mathrm{E}>0.18 \mathrm{MeV})\end{array}$ & \multicolumn{3}{c}{ Temperature $^{\mathrm{d}}$} \\
\hline AGR-2 5-4-2 & LEU09-OP2-Z059 & UCO & $12.03 \%$ & & TA $_{\min }$ & TA $_{\max }$ \\
\hline
\end{tabular}

${ }^{a}$ The X-Y-Z compact identification (ID) convention denotes the location in the irradiation test train: Capsule-LevelStack [Collin 2014].

${ }^{b}$ Physical properties data for individual compacts are available and tabulated based on fabrication ID [Hunn, Montgomery, and Pappano 2010a, pages 60-69].

${ }^{c}$ Burnup [Sterbentz 2014, table 6] and fast fluence [Sterbentz 2014, table 12] are based on physics calculations.

${ }^{d}$ Time-averaged, volume-averaged (TAVA) temperature, time-averaged minimum $\left(\mathrm{TA}_{\min }\right)$ temperature, and timeaveraged maximum $\left(\mathrm{TA}_{\max }\right)$ temperature is based on thermal calculations [Hawkes 2014, table 3]. 


\section{RESULTS OF DECONSOLIDATION LEACH-BURN-LEACH}

As-irradiated AGR-2 UCO Compact 5-4-2 was subjected to DLBL as described in detail in [Hunn et al. 2013a]. Figure 1 is a flow diagram copied from that report to provide a reference for the discussion in this section.

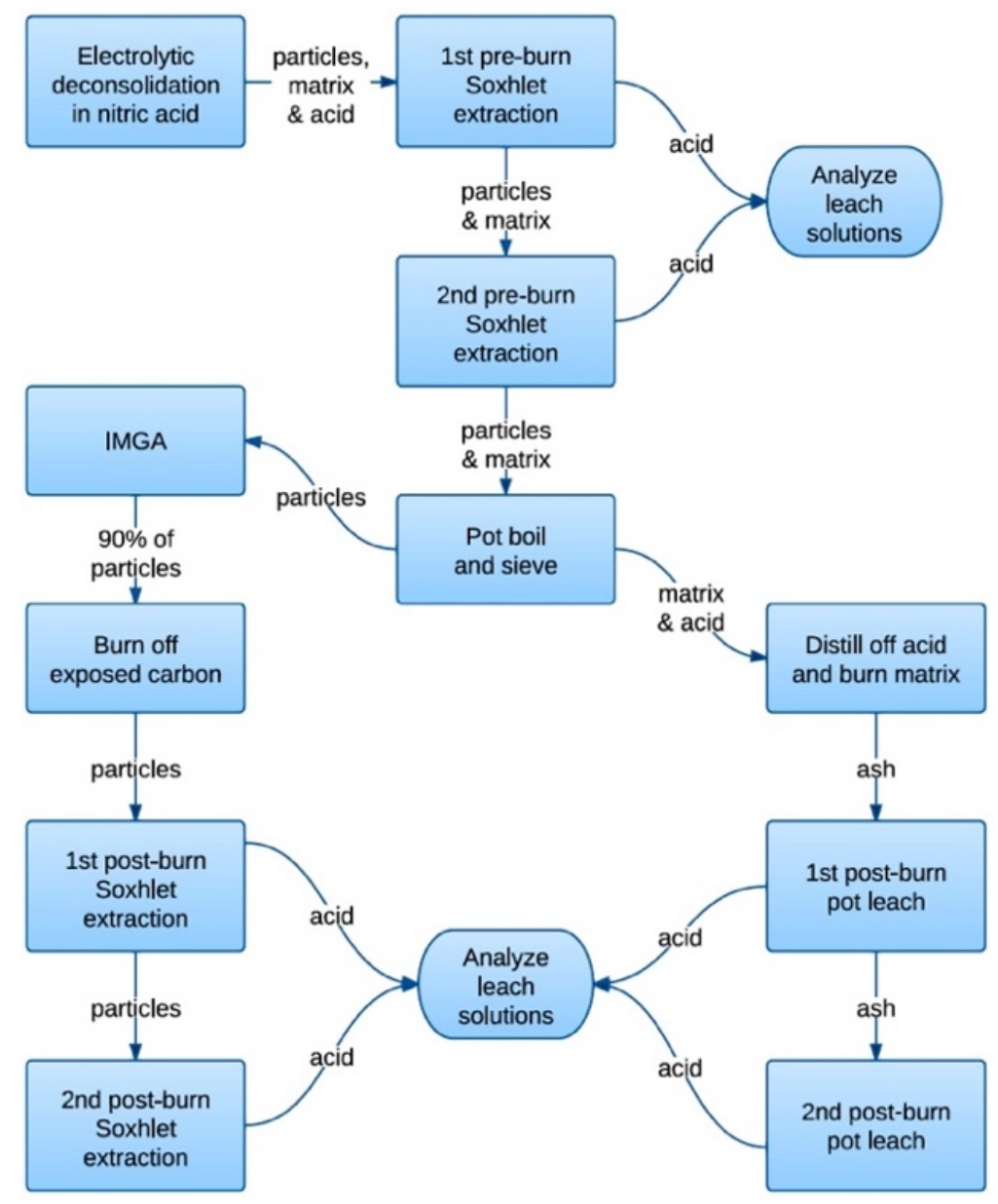

Figure 1. Flow diagram of compact DLBL processing.

Table 2 shows data for several isotopes of uranium and plutonium that are typically measured and useful for determining if kernels were exposed to the acid during the DLBL process. Analysis of the acid leachates from deconsolidation and pre-burn leaching detected exposed uranium and plutonium at $<7.4 \%$ of one particle-equivalent (i.e., $<2.32 \mathrm{E}-5$ where $3.15 \mathrm{E}-4$ is the compact inventory fraction in an average particle). Similar levels of exposed uranium and plutonium were detected in the post-burn matrix leach. The amount of uranium and plutonium detected in the post-burn particle leach was much higher and indicative of one exposed kernel. Two possible conclusions are that there was one particle with defective $\mathrm{SiC}$ in Compact 5-4-2 or that one particle was damaged between the second pre-burn extraction and the end of the first particle post-burn extraction, possibly during the sieving to separate particles from matrix or during the IMGA particle handling. It is expected that a particle with defective $\mathrm{SiC}$ would have been detected by IMGA and removed from the post-burn particle aliquot unless $\mathrm{SiC}$ failure happened near the end of the irradiation such that cesium release was negligible. Gamma scanning of the graphite holder from AGR-2 irradiation Capsule 5 also did not indicate significant cesium release from Compact 5-4-2 [Harp, Demkowicz, and Stempien 2016]. If there was no particle with defective $\mathrm{SiC}$, then the uranium and plutonium detected in the pre-burn leach and matrix post-burn leach was from diffusion through intact $\mathrm{SiC}$ during irradiation, because the measured levels are higher than the average fraction of tramp 
uranium measured in the AGR-2 UCO compacts before irradiation, which was 3.9E-6 with a standard deviation of $0.2 \mathrm{E}-6(\leq 4.1 \mathrm{E}-6$ at $95 \%$ confidence). This value of tramp uranium was determined from the DLBL results of thirteen analyzed compact clutches of five unirradiated compacts each where there were no indications of exposed kernels [Hunn 2010].

Table 2. Exposed compact inventory fractions ${ }^{a}$ of $U$ and Pu detected by DLBL

\begin{tabular}{lccccc}
\hline LBL Step & ${ }^{235} \mathbf{U}$ & ${ }^{236} \mathbf{U}$ & ${ }^{238} \mathbf{U}$ & ${ }^{239} \mathbf{P u}$ & ${ }^{240} \mathbf{P u}$ \\
\hline Deconsolidation acid & $3.49 \mathrm{E}-6$ & $3.09 \mathrm{E}-6$ & $1.03 \mathrm{E}-5$ & $6.79 \mathrm{E}-6$ & $8.81 \mathrm{E}-6$ \\
Pre-burn leach 1 & $1.33 \mathrm{E}-6$ & $1.34 \mathrm{E}-6$ & $4.57 \mathrm{E}-6$ & $3.57 \mathrm{E}-6$ & $4.72 \mathrm{E}-6$ \\
Pre-burn leach 2 & $1.45 \mathrm{E}-6$ & $2.22 \mathrm{E}-6$ & $8.38 \mathrm{E}-6$ & $6.36 \mathrm{E}-6$ & $8.92 \mathrm{E}-6$ \\
Post-burn particle leach 1 ${ }^{b}$ & $4.32 \mathrm{E}-4$ & $3.84 \mathrm{E}-4$ & $3.90 \mathrm{E}-4$ & $3.78 \mathrm{E}-4$ & $4.41 \mathrm{E}-4$ \\
Post-burn particle leach ${ }^{b}$ & $1.44 \mathrm{E}-6$ & $1.27 \mathrm{E}-6$ & $3.02 \mathrm{E}-6$ & $2.86 \mathrm{E}-6$ & $4.32 \mathrm{E}-6$ \\
Post-burn matrix leach 1 & $6.70 \mathrm{E}-6$ & $3.62 \mathrm{E}-6$ & $1.49 \mathrm{E}-5$ & $1.40 \mathrm{E}-5$ & $2.31 \mathrm{E}-5$ \\
Post-burn matrix leach 2 & $3.53 \mathrm{E}-7$ & $4.69 \mathrm{E}-7$ & $2.45 \mathrm{E}-6$ & $1.83 \mathrm{E}-6$ & $2.42 \mathrm{E}-6$ \\
\hline Total & $4.47 \mathrm{E}-4$ & $3.96 \mathrm{E}-4$ & $4.34 \mathrm{E}-4$ & $4.14 \mathrm{E}-4$ & $4.94 \mathrm{E}-4$ \\
Equivalent particle inventory ${ }^{c}$ & 1.4 & 1.3 & 1.4 & 1.3 & 1.6 \\
\hline
\end{tabular}

${ }^{a}$ Compact inventory fractions are the measured grams of each actinide divided by the calculated compact inventory of that actinide one year after the end of the irradiation. Values that primarily contributed to the total for each isotope are highlighted. Numbers in gray are low compared to possible background.

${ }^{b}$ The measured post-burn particle data was multiplied by $2772 / 3176$ to account for 404 particles held out of the sample after IMGA analysis.

${ }^{c}$ Equivalent particle inventory is the compact fraction times the average number of particles per compact (3176) and provides an indication of the number of exposed kernels; a compact fraction of 3.15E-4 is equivalent to one particle.

Table 3 and Table 4 show the DLBL data for typically-tracked beta/gamma-emitting fission products and some stable isotopes of interest, respectively. The first post-burn particle leach data should be interpreted with recognition of the contributions from the exposed kernel discussed above; this dominated the total measured strontium, antimony, and cesium releases. Silver released through intact SiC during irradiation but retained in the compact matrix and/or outer pyrolytic carbon (OPyC) was mostly collected in the deconsolidation acid and first pre-burn leachate, and the total silver release was in the typical range observed for AGR-1 compacts. 
Table 3. Exposed compact inventory fractions ${ }^{a}$ of typically-tracked beta/gamma-emitting fission products detected by DLBL

\begin{tabular}{|c|c|c|c|c|c|c|c|c|c|}
\hline LBL Step & ${ }^{90} \mathrm{Sr}^{b}$ & ${ }^{106} \mathbf{R u}$ & ${ }^{110 m} \mathrm{Ag}$ & ${ }^{125} \mathrm{Sb}$ & ${ }^{134} \mathrm{Cs}$ & ${ }^{137} \mathrm{Cs}$ & ${ }^{144} \mathrm{Ce}$ & ${ }^{154} \mathbf{E u}$ & ${ }^{155} \mathbf{E u}$ \\
\hline Deconsolidation acid & $5.08 \mathrm{E}-5$ & $<1.54 \mathrm{E}-6$ & $3.68 \mathrm{E}-3$ & $<3.80 \mathrm{E}-6$ & $1.98 \mathrm{E}-7$ & $2.48 \mathrm{E}-6$ & $9.66 \mathrm{E}-7$ & $8.72 \mathrm{E}-5$ & $1.01 \mathrm{E}-4$ \\
\hline Pre-burn leach 1 & $5.65 \mathrm{E}-5$ & $1.45 \mathrm{E}-6$ & $1.01 \mathrm{E}-3$ & $<2.39 \mathrm{E}-6$ & $3.07 \mathrm{E}-7$ & $1.92 \mathrm{E}-6$ & $2.12 \mathrm{E}-6$ & $1.47 \mathrm{E}-4$ & $1.60 \mathrm{E}-4$ \\
\hline Pre-burn leach 2 & $4.85 \mathrm{E}-6$ & $<8.21 \mathrm{E}-7$ & $<9.17 \mathrm{E}-5$ & $<2.61 \mathrm{E}-6$ & $1.70 \mathrm{E}-7$ & $2.18 \mathrm{E}-6$ & $9.77 \mathrm{E}-6$ & $2.47 \mathrm{E}-5$ & $2.75 \mathrm{E}-5$ \\
\hline Post-burn particle leach $1^{c}$ & $2.35 \mathrm{E}-4$ & $8.42 \mathrm{E}-6$ & $<5.97 \mathrm{E}-4$ & $1.53 \mathrm{E}-4$ & $1.44 \mathrm{E}-4$ & $1.91 \mathrm{E}-4$ & $5.41 \mathrm{E}-4$ & $3.55 \mathrm{E}-4$ & $3.91 \mathrm{E}-4$ \\
\hline Post-burn particle leach $2^{c}$ & $1.10 \mathrm{E}-6$ & $1.30 \mathrm{E}-6$ & $<8.43 \mathrm{E}-5$ & $<2.86 \mathrm{E}-6$ & $4.11 \mathrm{E}-6$ & $6.05 \mathrm{E}-6$ & $5.16 \mathrm{E}-6$ & $2.69 \mathrm{E}-6$ & $<1.86 \mathrm{E}-6$ \\
\hline Post-burn matrix leach 1 & $2.74 \mathrm{E}-5$ & $<8.44 \mathrm{E}-7$ & $<6.52 \mathrm{E}-5$ & $<2.17 \mathrm{E}-6$ & $1.78 \mathrm{E}-7$ & $2.61 \mathrm{E}-6$ & $3.41 \mathrm{E}-5$ & $2.60 \mathrm{E}-4$ & $2.95 \mathrm{E}-4$ \\
\hline Post-burn matrix leach 2 & $4.95 \mathrm{E}-7$ & $<2.09 \mathrm{E}-7$ & $<2.55 \mathrm{E}-5$ & $<7.99 \mathrm{E}-7$ & $1.87 \mathrm{E}-8$ & 7.78E-7 & $5.82 \mathrm{E}-7$ & $7.44 \mathrm{E}-6$ & $8.18 \mathrm{E}-6$ \\
\hline Total & $3.76 \mathrm{E}-4$ & $1.12 \mathrm{E}-5$ & $4.69 \mathrm{E}-3$ & $1.53 \mathrm{E}-4$ & $1.49 \mathrm{E}-4$ & $2.07 \mathrm{E}-4$ & $5.94 \mathrm{E}-4$ & $8.84 \mathrm{E}-4$ & $9.82 \mathrm{E}-4$ \\
\hline Equivalent particle inventory ${ }^{d}$ & 1.2 & 0.04 & 15 & 0.49 & 0.47 & 0.66 & 1.9 & 2.8 & 3.1 \\
\hline
\end{tabular}

${ }^{a}$ Compact inventory fractions are the measured grams of each radioisotope decay-corrected and divided by the calculated compact inventory of that radioisotope one day after the end of the irradiation. Values that primarily contributed to the total for each isotope are highlighted. Numbers in gray are low compared to possible background. A less than value indicates the concentration in the leachate was below the minimum detectable limit and these values are not included in the totals.

${ }^{b}$ Chemical separation and beta analysis was used to measure ${ }^{90} \mathrm{Sr}$; other isotopes were measured by gamma spectrometry.

${ }^{c}$ The measured post-burn particle data was multiplied by 2772/3176 to account for 404 particles held out of the sample after IMGA analysis.

${ }^{d}$ Equivalent particle inventory is the compact fraction times the average number of particles per compact (3176); a compact fraction of 3.15E-4 is equivalent to one particle. 
Table 4. Exposed compact inventory fractions ${ }^{a}$ of stable isotopes of interest detected by DLBL

\begin{tabular}{|c|c|c|c|c|c|c|c|c|c|c|}
\hline LBL Step & ${ }^{105} \mathbf{P d}$ & ${ }^{109} \mathrm{Ag}$ & ${ }^{133} \mathrm{Cs}$ & ${ }^{139} \mathbf{L a}$ & ${ }^{140} \mathrm{Ce}$ & ${ }^{141} \operatorname{Pr}$ & ${ }^{146} \mathrm{Nd}$ & ${ }^{152} \mathrm{Sm}$ & ${ }^{153} \mathbf{E u}$ & ${ }^{156} \mathbf{G d}$ \\
\hline Deconsolidation acid & $2.17 \mathrm{E}-3$ & $3.47 \mathrm{E}-3$ & $3.98 \mathrm{E}-5$ & $6.36 \mathrm{E}-5$ & $4.50 \mathrm{E}-5$ & $8.57 \mathrm{E}-6$ & $6.41 \mathrm{E}-6$ & $8.88 \mathrm{E}-5$ & $1.16 \mathrm{E}-4$ & $1.28 \mathrm{E}-4$ \\
\hline Pre-burn leach 1 & $1.46 \mathrm{E}-2$ & $1.07 \mathrm{E}-3$ & $3.79 \mathrm{E}-6$ & $9.83 \mathrm{E}-5$ & $8.73 \mathrm{E}-5$ & $1.07 \mathrm{E}-5$ & $7.38 \mathrm{E}-6$ & $1.17 \mathrm{E}-4$ & $1.77 \mathrm{E}-4$ & $1.95 \mathrm{E}-4$ \\
\hline Pre-burn leach 2 & $3.47 \mathrm{E}-4$ & $7.83 \mathrm{E}-5$ & $2.67 \mathrm{E}-6$ & $2.14 \mathrm{E}-5$ & $3.04 \mathrm{E}-5$ & $1.41 \mathrm{E}-5$ & $1.18 \mathrm{E}-5$ & $3.62 \mathrm{E}-5$ & $3.22 \mathrm{E}-5$ & $8.65 \mathrm{E}-5$ \\
\hline Post-burn particle leach $1^{b}$ & $3.99 \mathrm{E}-4$ & $2.63 \mathrm{E}-4$ & $1.86 \mathrm{E}-4$ & $6.13 \mathrm{E}-4$ & $7.98 \mathrm{E}-4$ & $6.12 \mathrm{E}-4$ & $5.42 \mathrm{E}-4$ & $1.14 \mathrm{E}-3$ & $4.87 \mathrm{E}-4$ & $2.42 \mathrm{E}-3$ \\
\hline Post-burn particle leach $2^{b}$ & $1.63 \mathrm{E}-4$ & $2.49 \mathrm{E}-5$ & $6.10 \mathrm{E}-6$ & $3.62 \mathrm{E}-6$ & $1.29 \mathrm{E}-5$ & $3.24 \mathrm{E}-6$ & $3.25 \mathrm{E}-6$ & $<6.80 \mathrm{E}-6$ & $<1.00 \mathrm{E}-5$ & $2.82 \mathrm{E}-5$ \\
\hline Post-burn matrix leach 1 & $6.14 \mathrm{E}-3$ & $1.95 \mathrm{E}-4$ & $3.01 \mathrm{E}-6$ & $8.27 \mathrm{E}-5$ & $1.07 \mathrm{E}-4$ & $4.56 \mathrm{E}-5$ & $3.83 \mathrm{E}-5$ & $1.86 \mathrm{E}-4$ & $2.53 \mathrm{E}-4$ & $3.45 \mathrm{E}-4$ \\
\hline Post-burn matrix leach 2 & $3.67 \mathrm{E}-5$ & $<1.20 \mathrm{E}-5$ & $8.40 \mathrm{E}-7$ & $1.73 \mathrm{E}-6$ & $4.83 \mathrm{E}-6$ & $1.21 \mathrm{E}-6$ & $1.17 \mathrm{E}-6$ & $<3.94 \mathrm{E}-6$ & $<5.80 \mathrm{E}-6$ & $<1.02 \mathrm{E}-5$ \\
\hline Total & $2.39 \mathrm{E}-2$ & $5.10 \mathrm{E}-3$ & $2.42 \mathrm{E}-4$ & $8.84 \mathrm{E}-4$ & $1.09 \mathrm{E}-3$ & $6.96 \mathrm{E}-4$ & $6.10 \mathrm{E}-4$ & $1.56 \mathrm{E}-3$ & $1.07 \mathrm{E}-3$ & $3.20 \mathrm{E}-3$ \\
\hline Equivalent particle inventory ${ }^{c}$ & 76 & 16 & 0.77 & 2.8 & 3.4 & 2.2 & 1.9 & 5.0 & 3.4 & 10 \\
\hline
\end{tabular}

${ }^{a}$ Compact inventory fractions are the measured grams of each stable isotope divided by the calculated compact inventory of that isotope one year after the end of the irradiation. Values that primarily contributed to the total for each isotope are highlighted. Numbers in gray are low compared to possible background. A less than value indicates the concentration in the leachate was below the minimum detectable limit and these values are not included in the totals.

${ }^{b}$ The measured post-burn particle data was multiplied by 2772/3176 to account for 404 particles held out of the sample after IMGA analysis.

${ }^{c}$ Equivalent particle inventory is the compact fraction times the average number of particles per compact (3176); a compact fraction of 3.15E-4 is equivalent to one particle. 


\section{INDIVIDUAL PARTICLE GAMMA ANALYSIS}

After deconsolidation of the compact and separation of the TRISO-coated particles from the compact matrix, each recovered particle was individually surveyed for relative ${ }^{144} \mathrm{Ce}$ and ${ }^{137} \mathrm{Cs}$ inventory with the IMGA using a 100-second gamma spectrum collection time for each particle. The IMGA equipment and methodology is described in detail in [Hunn et al. 2013a]. All measured activities were decay-corrected to one day after the end of the irradiation for comparison against the average calculated inventory.

Plotted in Figure 2 is a histogram of the measured ${ }^{144} \mathrm{Ce}$ activity for each particle, $\mathrm{A}_{\mathrm{i}}\left({ }^{144} \mathrm{Ce}\right)$, normalized to the measured mean value for all $n=3197$ surveyed particles (see equation in figure). Figure 3 is a similar plot of the measured ${ }^{137} \mathrm{Cs}$ activity. Figure 4 shows the measured ${ }^{137} \mathrm{Cs}$ activity in each particle, divided by an estimation of the calculated ${ }^{137} \mathrm{Cs}$ inventory for that particle if cesium were fully-retained (a quantity that will be denoted as $\mathrm{M} / \mathrm{C}$ ). The calculated ${ }^{137} \mathrm{Cs}$ inventory in each particle was estimated from the average calculated inventory in a single particle $\mathrm{A}_{\text {calc }}\left({ }^{137} \mathrm{Cs}\right)$ multiplied by the normalized ${ }^{144} \mathrm{Ce}$ activity in that particular particle (from Figure 2) to adjust for particle-to-particle variation in initial fissile content and burnup (see equation in Figure 4). The average calculated inventory in a single particle came from the calculated inventory in the compact one day after the end of the irradiation [Sterbentz 2014] divided by the average number of particles in an AGR-2 UCO compact (3176), which was determined by analyzing 20 compacts during pre-irradiation characterization [Hunn, Montgomery, and Pappano 2010a]. No particles were detected with ${ }^{144} \mathrm{Ce}$ and ${ }^{137} \mathrm{Cs}$ inventories significantly outside of the main distribution.

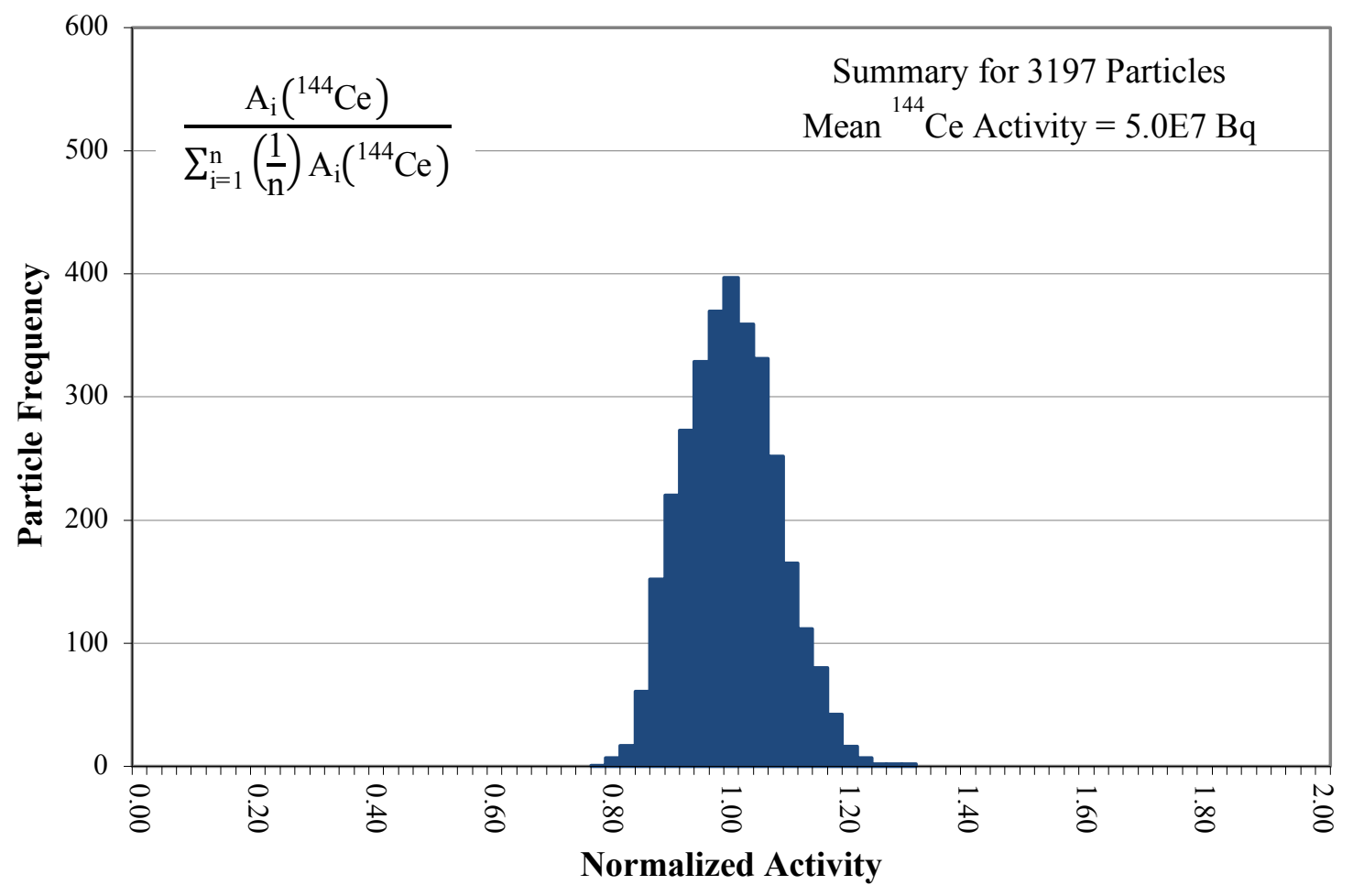

Figure 2. Particle distribution for measured ${ }^{144}$ Ce activity, normalized to the average. 


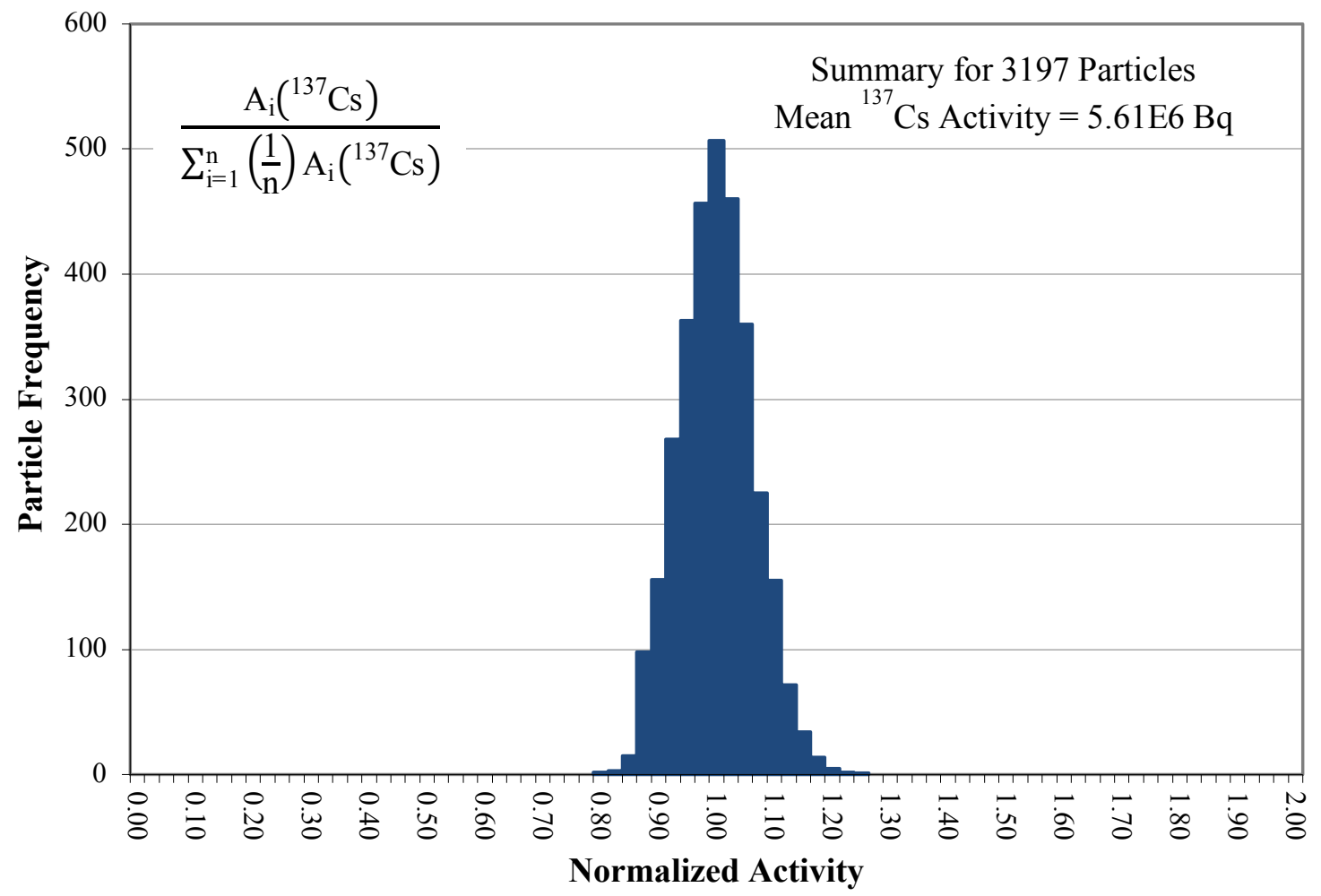

Figure 3. Particle distribution for measured ${ }^{137} \mathrm{Cs}$ activity, normalized to the average.

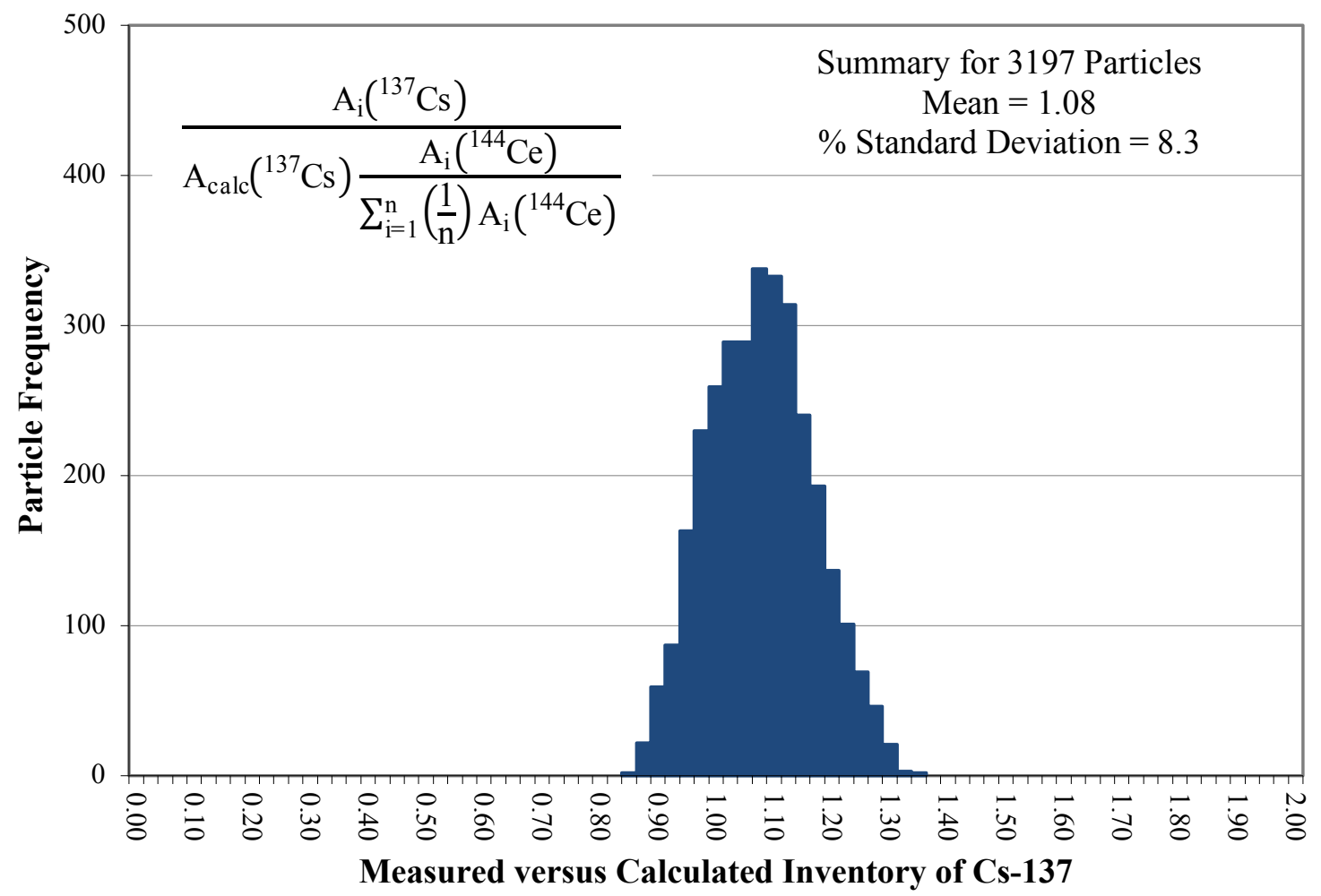

Figure 4. Ratio of ${ }^{137} \mathrm{Cs}$ retained in 3190 particles versus the calculated inventory, adjusted for variation in fissionable material and burnup with the measured ${ }^{144} \mathrm{Ce}$ activity. 
The number of particle surveys (3197) used to generate the Compact 5-4-2 histograms in Figure 2-Figure 4 was 91 higher than the number of particles counted prior to survey (3106). This indicates that either some particles were analyzed more than once or not all particles were counted prior to the IMGA survey. Standard procedure is to photograph particles prior to loading them into the IMGA for survey. Particle counting is performed using automated image analysis software to count and mark each counted particle in a saved image for review. Manual review of the marked images is performed to confirm the accuracy of the count. There were only 3106 particles photographed and counted prior to Compact 5-4-2 IMGA, which is unusually low compared to the compact average (3176), given the typical efficiency of DLBL particle recovery. The IMGA survey was done during a staff transition and training period, so it is possible one set of particles may not have been imaged by mistake.

It is also possible that some particles were surveyed more than once. Standard procedure is to reanalyze particles that are dropped during transport between the particle storage carousel and the gamma counting position. This is considered to be the best practice because the primary purpose of the short-count IMGA survey is to identify and separate out particles with abnormal ${ }^{144} \mathrm{Ce}$ or ${ }^{137} \mathrm{Cs}$ inventory, so it is undesirable to leave any particles unanalyzed. Trays are situated along the particle transfer path to facilitate the recovery of dropped particles. Dropped particles usually come from the needle picking up more than one particle. If more than one particle is gamma counted, the IMGA automatically marks the spectrum for deletion and places these particles in a "multiload" vial for reanalysis. Multiload particles sometimes drop off on the way to or from the gamma counting position. Reloading these dropped particles for analysis will not result in multiple data records for the same particle because the multiload data is deleted. However, there were problems with the IMGA vacuum needle system during the Compact 5-4-2 IMGA survey that may have resulted in single-load particles being dropped after they were gamma counted, which would result in multiple data records if these particles were recovered and reanalyzed. Dropping of a single-load particle is a very unusual event when the vacuum needle is working properly.

After short-count IMGA survey, forty-four particles were randomly selected for four-hour gamma counting. This long-count analysis allows for lower activity isotopes to be quantified. Table 5 shows the long-count IMGA data for each individual particle.

Table 5. Results from 4-hour gamma scanning of 44 randomly-selected (RS) particles showing measured activity in Bq/particle decay-corrected to EOL+1 day

\begin{tabular}{|c|c|c|c|c|c|c|c|}
\hline Particle & ${ }^{106} \mathrm{Ru}$ & ${ }^{110 \mathrm{~m}} \mathbf{A g}{ }^{a}$ & ${ }^{125} \mathrm{Sb}$ & ${ }^{134} \mathrm{Cs}$ & ${ }^{137} \mathrm{Cs}$ & ${ }^{144} \mathrm{Ce}$ & ${ }^{154} \mathbf{E u}$ \\
\hline 542-RS01 & $1.47 \mathrm{E}+7$ & $<9.72 \mathrm{E}+3$ & $2.57 \mathrm{E}+5$ & $5.16 \mathrm{E}+6$ & $5.18 \mathrm{E}+6$ & $5.05 \mathrm{E}+7$ & $1.62 \mathrm{E}+5$ \\
\hline 542-RS02 & $1.58 \mathrm{E}+7$ & $<9.88 \mathrm{E}+3$ & $2.71 \mathrm{E}+5$ & $5.25 \mathrm{E}+6$ & $5.50 \mathrm{E}+6$ & $5.44 \mathrm{E}+7$ & $1.70 \mathrm{E}+5$ \\
\hline 542-RS03 & $1.60 \mathrm{E}+7$ & $5.13 \mathrm{E}+4$ & $2.72 \mathrm{E}+5$ & $5.74 \mathrm{E}+6$ & $5.55 \mathrm{E}+6$ & $5.07 \mathrm{E}+7$ & $1.87 \mathrm{E}+5$ \\
\hline 542-RS04 & $1.72 \mathrm{E}+7$ & $6.55 \mathrm{E}+4$ & $2.99 \mathrm{E}+5$ & $5.88 \mathrm{E}+6$ & $5.95 \mathrm{E}+6$ & $5.43 \mathrm{E}+7$ & $1.92 \mathrm{E}+5$ \\
\hline 542-RS05 & $1.73 \mathrm{E}+7$ & $<1.03 \mathrm{E}+4$ & $2.85 \mathrm{E}+5$ & $5.62 \mathrm{E}+6$ & $5.69 \mathrm{E}+6$ & $5.59 \mathrm{E}+7$ & $1.81 \mathrm{E}+5$ \\
\hline 542-RS06 & $1.54 \mathrm{E}+7$ & $6.78 \mathrm{E}+4$ & $2.71 \mathrm{E}+5$ & $5.97 \mathrm{E}+6$ & $5.50 \mathrm{E}+6$ & $4.48 \mathrm{E}+7$ & $1.99 \mathrm{E}+5$ \\
\hline 542-RS07 & $1.74 \mathrm{E}+7$ & $<1.05 \mathrm{E}+4$ & $2.91 \mathrm{E}+5$ & $5.75 \mathrm{E}+6$ & $5.77 \mathrm{E}+6$ & $5.44 \mathrm{E}+7$ & $1.90 \mathrm{E}+5$ \\
\hline 542-RS08 & $1.84 \mathrm{E}+7$ & $6.01 \mathrm{E}+4$ & $3.05 \mathrm{E}+5$ & $6.86 \mathrm{E}+6$ & $6.37 \mathrm{E}+6$ & $5.18 \mathrm{E}+7$ & $2.31 \mathrm{E}+5$ \\
\hline 542-RS09 & $1.52 \mathrm{E}+7$ & $5.17 \mathrm{E}+4$ & $2.64 \mathrm{E}+5$ & $4.94 \mathrm{E}+6$ & $5.17 \mathrm{E}+6$ & $5.25 \mathrm{E}+7$ & $1.59 \mathrm{E}+5$ \\
\hline 542-RS10 & $1.52 \mathrm{E}+7$ & $7.63 \mathrm{E}+3$ & $2.61 \mathrm{E}+5$ & $4.90 \mathrm{E}+6$ & $5.16 \mathrm{E}+6$ & $5.48 \mathrm{E}+7$ & $1.55 \mathrm{E}+5$ \\
\hline 542-RS11 & $1.52 \mathrm{E}+7$ & $1.32 \mathrm{E}+4$ & $2.72 \mathrm{E}+5$ & $5.47 \mathrm{E}+6$ & $5.58 \mathrm{E}+6$ & $5.44 \mathrm{E}+7$ & $1.73 \mathrm{E}+5$ \\
\hline 542-RS12 & $1.36 \mathrm{E}+7$ & $<1.00 \mathrm{E}+4$ & $2.36 \mathrm{E}+5$ & $4.91 \mathrm{E}+6$ & $4.94 \mathrm{E}+6$ & $4.84 \mathrm{E}+7$ & $1.53 \mathrm{E}+5$ \\
\hline 542-RS13 & $1.48 \mathrm{E}+7$ & $5.17 \mathrm{E}+4$ & $2.53 \mathrm{E}+5$ & $5.05 \mathrm{E}+6$ & $5.03 \mathrm{E}+6$ & $4.96 \mathrm{E}+7$ & $1.63 \mathrm{E}+5$ \\
\hline 542-RS14 & $1.81 \mathrm{E}+7$ & $5.86 \mathrm{E}+4$ & $2.97 \mathrm{E}+5$ & $6.67 \mathrm{E}+6$ & $6.11 \mathrm{E}+6$ & $5.06 \mathrm{E}+7$ & $2.26 \mathrm{E}+5$ \\
\hline 542-RS15 & $1.50 \mathrm{E}+7$ & $1.39 \mathrm{E}+4$ & $2.70 \mathrm{E}+5$ & $5.30 \mathrm{E}+6$ & $5.43 \mathrm{E}+6$ & $5.18 \mathrm{E}+7$ & $1.73 \mathrm{E}+5$ \\
\hline 542-RS17 & $1.63 \mathrm{E}+7$ & $2.94 \mathrm{E}+4$ & $2.74 \mathrm{E}+5$ & $5.38 \mathrm{E}+6$ & $5.43 \mathrm{E}+6$ & $5.25 \mathrm{E}+7$ & $1.74 \mathrm{E}+5$ \\
\hline 542-RS18 & $1.44 \mathrm{E}+7$ & $2.40 \mathrm{E}+4$ & $2.49 \mathrm{E}+5$ & $4.59 \mathrm{E}+6$ & $4.89 \mathrm{E}+6$ & $5.15 \mathrm{E}+7$ & $1.48 \mathrm{E}+5$ \\
\hline 542-RS19 & $1.77 \mathrm{E}+7$ & $4.34 \mathrm{E}+4$ & $3.05 \mathrm{E}+5$ & $6.12 \mathrm{E}+6$ & $6.03 \mathrm{E}+6$ & $5.30 \mathrm{E}+7$ & $1.99 \mathrm{E}+5$ \\
\hline $542-R S 20$ & $1.76 \mathrm{E}+7$ & $3.85 \mathrm{E}+4$ & $3.05 \mathrm{E}+5$ & $6.34 \mathrm{E}+6$ & $6.19 \mathrm{E}+6$ & $5.42 \mathrm{E}+7$ & $2.08 \mathrm{E}+5$ \\
\hline 542-RS21 & $1.44 \mathrm{E}+7$ & $2.90 \mathrm{E}+4$ & $2.45 \mathrm{E}+5$ & $4.84 \mathrm{E}+6$ & $4.91 \mathrm{E}+6$ & $4.93 \mathrm{E}+7$ & $1.57 \mathrm{E}+5$ \\
\hline 542-RS22 & $1.76 \mathrm{E}+7$ & $<1.08 \mathrm{E}+4$ & $2.96 \mathrm{E}+5$ & $5.72 \mathrm{E}+6$ & $5.87 \mathrm{E}+6$ & $6.08 \mathrm{E}+7$ & $1.83 \mathrm{E}+5$ \\
\hline
\end{tabular}


Table 5 (continued). Results from 4-hour gamma scanning of 44 randomly-selected (RS) particles showing measured activity in $\mathrm{Bq} /$ particle decay-corrected to EOL +1 day

\begin{tabular}{|c|c|c|c|c|c|c|c|}
\hline Particle & ${ }^{106} \mathrm{Ru}$ & ${ }^{110 \mathrm{~m}} \mathrm{Ag}^{a}$ & ${ }^{125} \mathrm{Sb}$ & ${ }^{134} \mathrm{Cs}$ & ${ }^{137} \mathrm{Cs}$ & ${ }^{144} \mathrm{Ce}$ & ${ }^{154} \mathbf{E u}$ \\
\hline 542-RS23 & $1.65 \mathrm{E}+7$ & $6.46 \mathrm{E}+4$ & $2.73 \mathrm{E}+5$ & $6.18 \mathrm{E}+6$ & $5.64 \mathrm{E}+6$ & $4.50 \mathrm{E}+7$ & $2.04 \mathrm{E}+5$ \\
\hline 542-RS24 & $1.67 \mathrm{E}+7$ & $6.82 \mathrm{E}+4$ & $2.91 \mathrm{E}+5$ & $5.93 \mathrm{E}+6$ & $5.73 E+6$ & $4.92 \mathrm{E}+7$ & $1.95 \mathrm{E}+5$ \\
\hline 542-RS25 & $1.69 \mathrm{E}+7$ & $6.00 \mathrm{E}+4$ & $2.81 \mathrm{E}+5$ & $5.82 \mathrm{E}+6$ & $5.72 \mathrm{E}+6$ & $5.17 \mathrm{E}+7$ & $1.94 \mathrm{E}+5$ \\
\hline $542-\mathrm{RS} 26$ & $1.71 \mathrm{E}+7$ & $6.01 \mathrm{E}+4$ & $2.75 \mathrm{E}+5$ & $5.80 \mathrm{E}+6$ & $5.43 \mathrm{E}+6$ & $4.71 \mathrm{E}+7$ & $1.94 \mathrm{E}+5$ \\
\hline 542-RS27 & $1.50 \mathrm{E}+7$ & $<1.05 \mathrm{E}+4$ & $2.68 \mathrm{E}+5$ & $5.21 \mathrm{E}+6$ & $5.31 \mathrm{E}+6$ & $5.38 \mathrm{E}+7$ & $1.66 \mathrm{E}+5$ \\
\hline 542-RS28 & $1.75 \mathrm{E}+7$ & $<1.07 \mathrm{E}+4$ & $2.88 \mathrm{E}+5$ & $5.35 \mathrm{E}+6$ & $5.55 \mathrm{E}+6$ & $5.88 \mathrm{E}+7$ & $1.74 \mathrm{E}+5$ \\
\hline 542-RS29 & $1.58 \mathrm{E}+7$ & $<1.00 \mathrm{E}+4$ & $2.65 \mathrm{E}+5$ & $4.78 \mathrm{E}+6$ & $5.18 \mathrm{E}+6$ & $5.58 \mathrm{E}+7$ & $1.55 \mathrm{E}+5$ \\
\hline $542-\mathrm{RS} 30$ & $1.41 \mathrm{E}+7$ & $1.67 \mathrm{E}+4$ & $2.51 \mathrm{E}+5$ & $5.24 \mathrm{E}+6$ & $5.17 \mathrm{E}+6$ & $4.75 \mathrm{E}+7$ & $1.64 \mathrm{E}+5$ \\
\hline 542-RS31 & $1.48 \mathrm{E}+7$ & $4.05 \mathrm{E}+4$ & $2.55 \mathrm{E}+5$ & $4.84 \mathrm{E}+6$ & $5.00 \mathrm{E}+6$ & $5.02 \mathrm{E}+7$ & $1.51 \mathrm{E}+5$ \\
\hline 542-RS32 & $1.57 \mathrm{E}+7$ & $4.85 \mathrm{E}+4$ & $2.70 \mathrm{E}+5$ & $5.14 \mathrm{E}+6$ & $5.24 \mathrm{E}+6$ & $5.22 \mathrm{E}+7$ & $1.68 \mathrm{E}+5$ \\
\hline 542-RS33 & $1.46 \mathrm{E}+7$ & $6.47 \mathrm{E}+4$ & $2.49 \mathrm{E}+5$ & $5.39 \mathrm{E}+6$ & $5.14 \mathrm{E}+6$ & $4.37 \mathrm{E}+7$ & $1.79 \mathrm{E}+5$ \\
\hline 542-RS34 & $1.63 \mathrm{E}+7$ & $2.05 \mathrm{E}+4$ & $2.76 \mathrm{E}+5$ & $5.31 \mathrm{E}+6$ & $5.44 \mathrm{E}+6$ & $5.41 \mathrm{E}+7$ & $1.72 \mathrm{E}+5$ \\
\hline 542-RS35 & $1.49 \mathrm{E}+7$ & $3.27 \mathrm{E}+4$ & $2.57 \mathrm{E}+5$ & $5.25 \mathrm{E}+6$ & $5.16 \mathrm{E}+6$ & $4.53 \mathrm{E}+7$ & $1.72 \mathrm{E}+5$ \\
\hline 542-RS36 & $1.44 \mathrm{E}+7$ & $4.51 \mathrm{E}+4$ & $2.49 \mathrm{E}+5$ & $5.34 \mathrm{E}+6$ & $5.20 \mathrm{E}+6$ & $4.59 \mathrm{E}+7$ & $1.77 \mathrm{E}+5$ \\
\hline 542-RS37 & $1.54 \mathrm{E}+7$ & $1.61 \mathrm{E}+4$ & $2.61 \mathrm{E}+5$ & $4.68 \mathrm{E}+6$ & $4.96 \mathrm{E}+6$ & $5.30 \mathrm{E}+7$ & $1.53 \mathrm{E}+5$ \\
\hline 542-RS38 & $1.47 \mathrm{E}+7$ & $3.77 \mathrm{E}+4$ & $2.53 \mathrm{E}+5$ & $5.32 \mathrm{E}+6$ & $5.23 \mathrm{E}+6$ & $4.66 \mathrm{E}+7$ & $1.69 \mathrm{E}+5$ \\
\hline 542-RS39 & $1.28 \mathrm{E}+7$ & $3.70 \mathrm{E}+4$ & $2.24 \mathrm{E}+5$ & $4.90 \mathrm{E}+6$ & $4.71 \mathrm{E}+6$ & $4.10 \mathrm{E}+7$ & $1.63 \mathrm{E}+5$ \\
\hline 542-RS40 & $1.45 \mathrm{E}+7$ & $5.33 \mathrm{E}+4$ & $2.40 \mathrm{E}+5$ & $4.58 \mathrm{E}+6$ & $4.74 \mathrm{E}+6$ & $4.95 \mathrm{E}+7$ & $1.48 \mathrm{E}+5$ \\
\hline 542-RS41 & $1.57 \mathrm{E}+7$ & $<1.05 \mathrm{E}+4$ & $2.73 \mathrm{E}+5$ & $5.27 \mathrm{E}+6$ & $5.46 \mathrm{E}+6$ & $5.67 \mathrm{E}+7$ & $1.68 \mathrm{E}+5$ \\
\hline 542-RS42 & $1.54 \mathrm{E}+7$ & $1.72 \mathrm{E}+4$ & $2.66 \mathrm{E}+5$ & $5.43 \mathrm{E}+6$ & $5.38 \mathrm{E}+6$ & $5.01 \mathrm{E}+7$ & $1.80 \mathrm{E}+5$ \\
\hline 542-RS43 & $1.44 \mathrm{E}+7$ & $<1.00 \mathrm{E}+4$ & $2.47 \mathrm{E}+5$ & $5.02 \mathrm{E}+6$ & $5.10 \mathrm{E}+6$ & $4.99 \mathrm{E}+7$ & $1.56 \mathrm{E}+5$ \\
\hline 542-RS44 & $1.57 \mathrm{E}+7$ & $3.20 \mathrm{E}+4$ & $2.72 \mathrm{E}+5$ & $5.51 \mathrm{E}+6$ & $5.39 \mathrm{E}+6$ & $4.82 \mathrm{E}+7$ & $1.69 \mathrm{E}+5$ \\
\hline 542-RS45 & $1.65 \mathrm{E}+7$ & $4.64 \mathrm{E}+4$ & $2.82 \mathrm{E}+5$ & $6.07 \mathrm{E}+6$ & $5.92 \mathrm{E}+6$ & $5.19 \mathrm{E}+7$ & $1.97 \mathrm{E}+5$ \\
\hline Maximum & $1.84 \mathrm{E}+7$ & $6.82 \mathrm{E}+4$ & $3.05 \mathrm{E}+5$ & $6.86 \mathrm{E}+6$ & $6.37 \mathrm{E}+6$ & $6.08 \mathrm{E}+7$ & $2.31 \mathrm{E}+5$ \\
\hline Minimum & $1.28 \mathrm{E}+7$ & $<9.72 \mathrm{E}+3$ & $2.24 \mathrm{E}+5$ & $4.58 \mathrm{E}+6$ & $4.71 \mathrm{E}+6$ & $4.10 \mathrm{E}+7$ & $1.48 \mathrm{E}+5$ \\
\hline Mean & $1.57 \mathrm{E}+7$ & $3.11-3.36 \mathrm{E}+4$ & $2.69 \mathrm{E}+5$ & $5.43 \mathrm{E}+6$ & $5.41 \mathrm{E}+6$ & $5.11 \mathrm{E}+7$ & $1.76 \mathrm{E}+5$ \\
\hline Std. Dev. & $8.3 \%$ & $77-62 \%$ & $7.2 \%$ & $9.8 \%$ & $7.2 \%$ & $7.9 \%$ & $11 \%$ \\
\hline
\end{tabular}

Figure 5, Figure 6, and Figure 7 plot the $\mathrm{M} / \mathrm{C}$ values for ${ }^{110 \mathrm{~m}} \mathrm{Ag},{ }^{144} \mathrm{Ce}$, and ${ }^{154} \mathrm{Eu}$, which were calculated similar to the method used for Figure 4, except the adjustment for particle-to-particle variation in initial fissile content and burnup used the normalized ${ }^{137} \mathrm{Cs}$ activity from the 44 randomly-selected particles. The ${ }^{110 \mathrm{~m}} \mathrm{Ag}$ distribution (Figure 5) showed a broad particle-to-particle variability in ${ }^{110 \mathrm{~m}} \mathrm{Ag} \mathrm{M} / \mathrm{C}$ ranging from essentially full retention to almost zero retention. This behavior has been observed in other AGR compacts [Demkowicz et al. 2015] and is conjectured to be primarily a function of the temperature history of each particle, which can vary several hundred degrees across the compact [Hawkes 2014]. Particles with different ${ }^{110 \mathrm{~m}} \mathrm{Ag} \mathrm{M} / \mathrm{C}$ values were selected for further analysis (Sections 4 and 5).

The ${ }^{144} \mathrm{Ce}$ and ${ }^{154} \mathrm{Eu}$ distributions (Figure 6 and Figure 7) were offset from $\mathrm{M} / \mathrm{C}=1$ but did not show significant particle-to-particle variability beyond what is typical for the spread caused by measurement uncertainty and variability in generated inventory. These offsets do not indicate that the average particle released fission products equivalent to the offsets. It is known that there are biases in some of the calculated inventories because of uncertainties in the input to the JMOCUP physics calculation [Sterbentz 2014]. Table 6 lists the biases observed in the AGR-1 experiment when the calculated values were compared to gamma scan data of the whole compacts with the INL Precision Gamma Scanner (PGS) [Harp et al. 2014]. The relatively-large offsets in the ${ }^{125} \mathrm{Sb}$ and ${ }^{154} \mathrm{Eu}$ measured-to-calculated ratios for Compact 5-4-2 are in the range of what was observed for AGR-1. The offsets in the ${ }^{106} \mathrm{Ru},{ }^{137} \mathrm{Cs}$, and ${ }^{144} \mathrm{Ce}$ measured-to-calculated ratios for Compact 5-4-2 are larger than what was typically observed for 
AGR-1 fuel but similar to what is being observed in IMGA measurement of particles from other AGR-2 compacts, so the bias in these values also appears to be related to the physics calculations.

Table 6. Summary of results from 4-hour IMGA analysis of Compact 5-4-2 particles

\begin{tabular}{|c|c|c|c|c|c|c|c|}
\hline \multirow{2}{*}{ Isotope } & \multirow{2}{*}{$\begin{array}{c}\text { Average } \\
\text { Calculated } \\
\text { Activity }^{a} \\
\text { (Bq/particle) }\end{array}$} & \multicolumn{2}{|c|}{$\begin{array}{l}\text { Measured Activity }{ }^{b} \\
(\mathrm{~Bq} / \text { particle })^{-}\end{array}$} & \multicolumn{2}{|c|}{$\begin{array}{c}\text { Ratio of Measured versus } \\
\text { Average Calculated Activity }\end{array}$} & \multicolumn{2}{|c|}{$\begin{array}{l}\text { Measured-to-Calculated Ratio } \\
\text { in AGR-1 Compact Activity }{ }^{d}\end{array}$} \\
\hline & & mean & std. dev. & mean & std. dev. & mean & std. dev. \\
\hline${ }^{106} \mathrm{Ru}$ & $1.39 \mathrm{E}+7$ & $1.57 \mathrm{E}+7$ & $8.3 \%$ & 1.14 & 0.09 & 0.96 & 0.04 \\
\hline${ }^{110 \mathrm{~m}} \mathrm{Ag}^{e}$ & $5.53 \mathrm{E}+4$ & $3.11 \mathrm{E}+4-3.36 \mathrm{E}+4$ & $77-62 \%$ & $0.56-0.61$ & $0.44-0.38$ & \multicolumn{2}{|c|}{ not in reference } \\
\hline${ }^{125} \mathrm{Sb}$ & $3.61 \mathrm{E}+5$ & $2.69 \mathrm{E}+5$ & $7.2 \%$ & 0.75 & 0.05 & 0.70 & 0.04 \\
\hline${ }^{134} \mathrm{Cs}$ & $5.46 \mathrm{E}+6$ & $5.43 \mathrm{E}+6$ & $9.8 \%$ & 0.99 & 0.10 & 0.97 & 0.05 \\
\hline${ }^{137} \mathrm{Cs}$ & $5.23 \mathrm{E}+6$ & $5.41 \mathrm{E}+6$ & $7.2 \%$ & 1.04 & 0.07 & 0.99 & 0.03 \\
\hline${ }^{144} \mathrm{Ce}$ & $4.73 \mathrm{E}+7$ & $5.11 \mathrm{E}+7$ & $7.9 \%$ & 1.08 & 0.09 & 1.00 & 0.04 \\
\hline${ }^{154} \mathrm{Eu}$ & $2.04 \mathrm{E}+5$ & $1.76 \mathrm{E}+5$ & $11 \%$ & 0.86 & 0.10 & 0.83 & 0.04 \\
\hline
\end{tabular}

${ }^{a}$ Calculated activity for one day after end of irradiation.

${ }^{b}$ Measured activity decay-corrected to one day after end of irradiation.

${ }^{c}$ Not the same as $\mathrm{M} / \mathrm{C}$, which is also adjusted for variation in fissionable material and burnup.

${ }^{d}$ Summary results from gamma scanning of whole AGR-1 compacts [Demkowicz et al. 2015, table 14].

${ }^{e}$ Values for ${ }^{110 \mathrm{~m}} \mathrm{Ag}$ are presented as a range where particles below the detection limit were treated as ranging from a minimum value of zero to a maximum value of the detection limit.

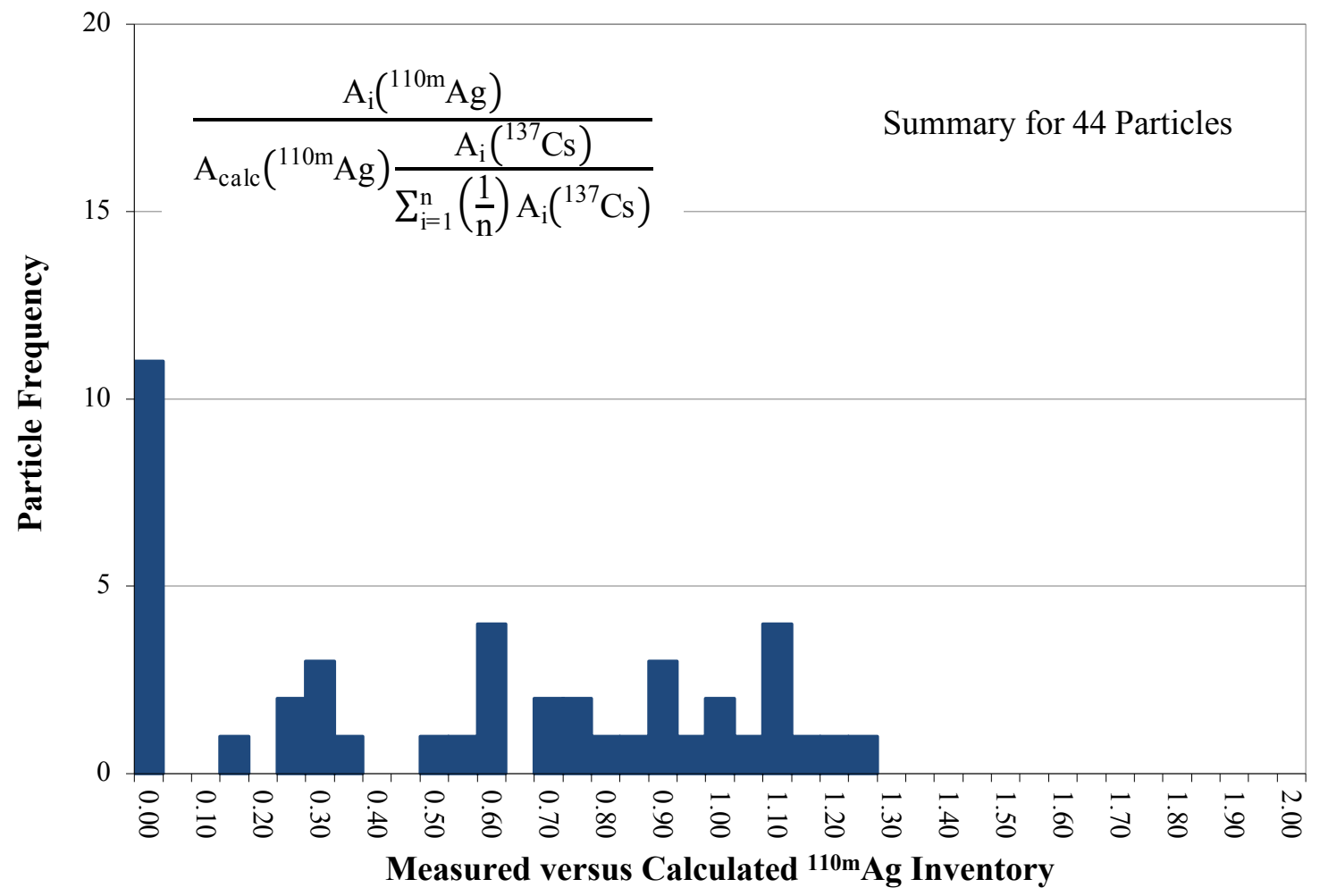

Figure 5. Ratio of ${ }^{110 \mathrm{~m}} \mathrm{Ag}$ retained in 44 particles versus the calculated inventory, adjusted for variation in fissionable material and burnup with the measured ${ }^{137} \mathrm{Cs}$ activity. Particles plotted as "zero" had a ${ }^{110 \mathrm{~m}} \mathrm{Ag} \mathrm{M} / \mathrm{C} \lesssim 19 \%$. 


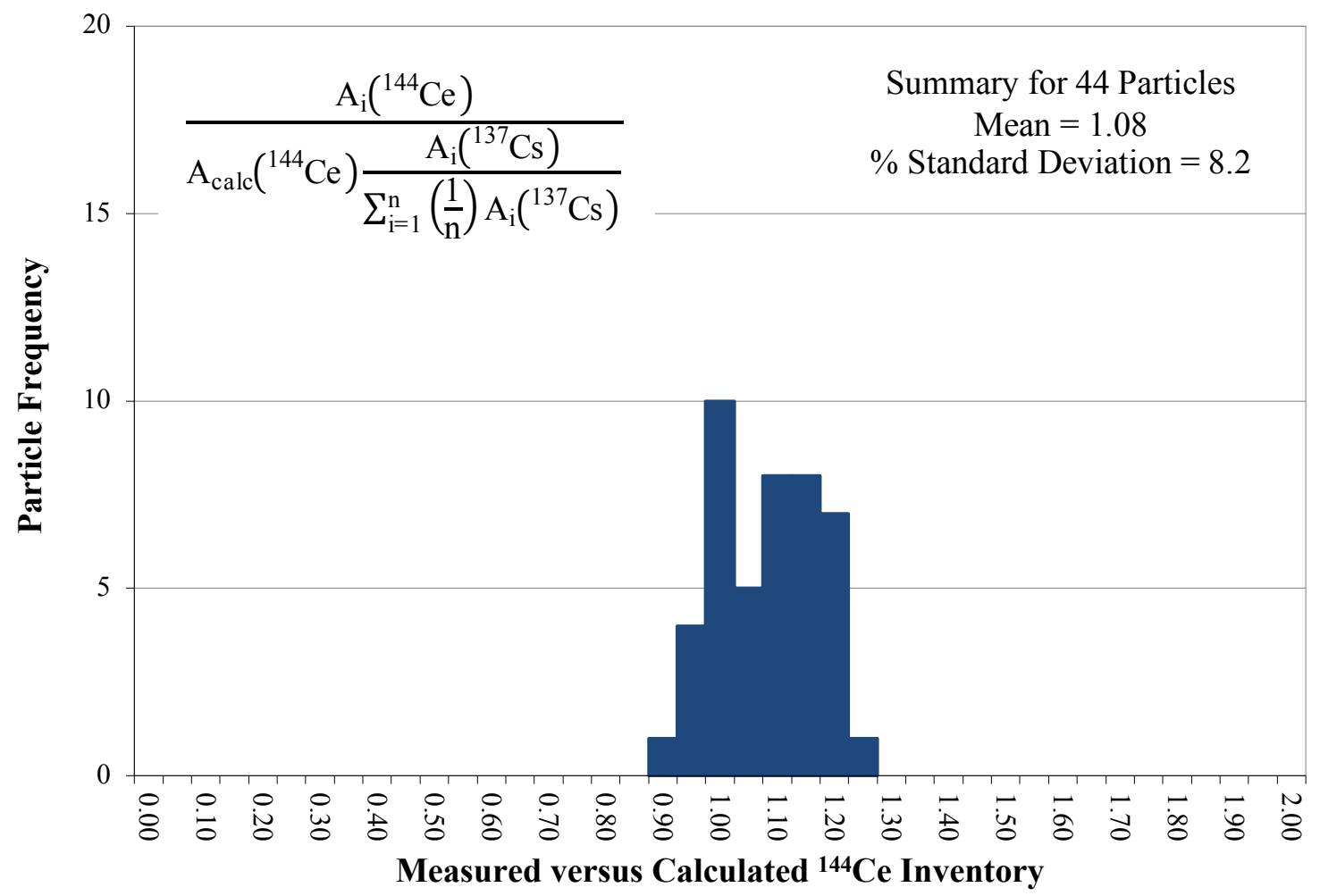

Figure 6. Ratio of ${ }^{144} \mathrm{Ce}$ retained in 44 particles versus the calculated inventory, adjusted for variation in fissionable material and burnup with the measured ${ }^{137} \mathrm{Cs}$ activity.

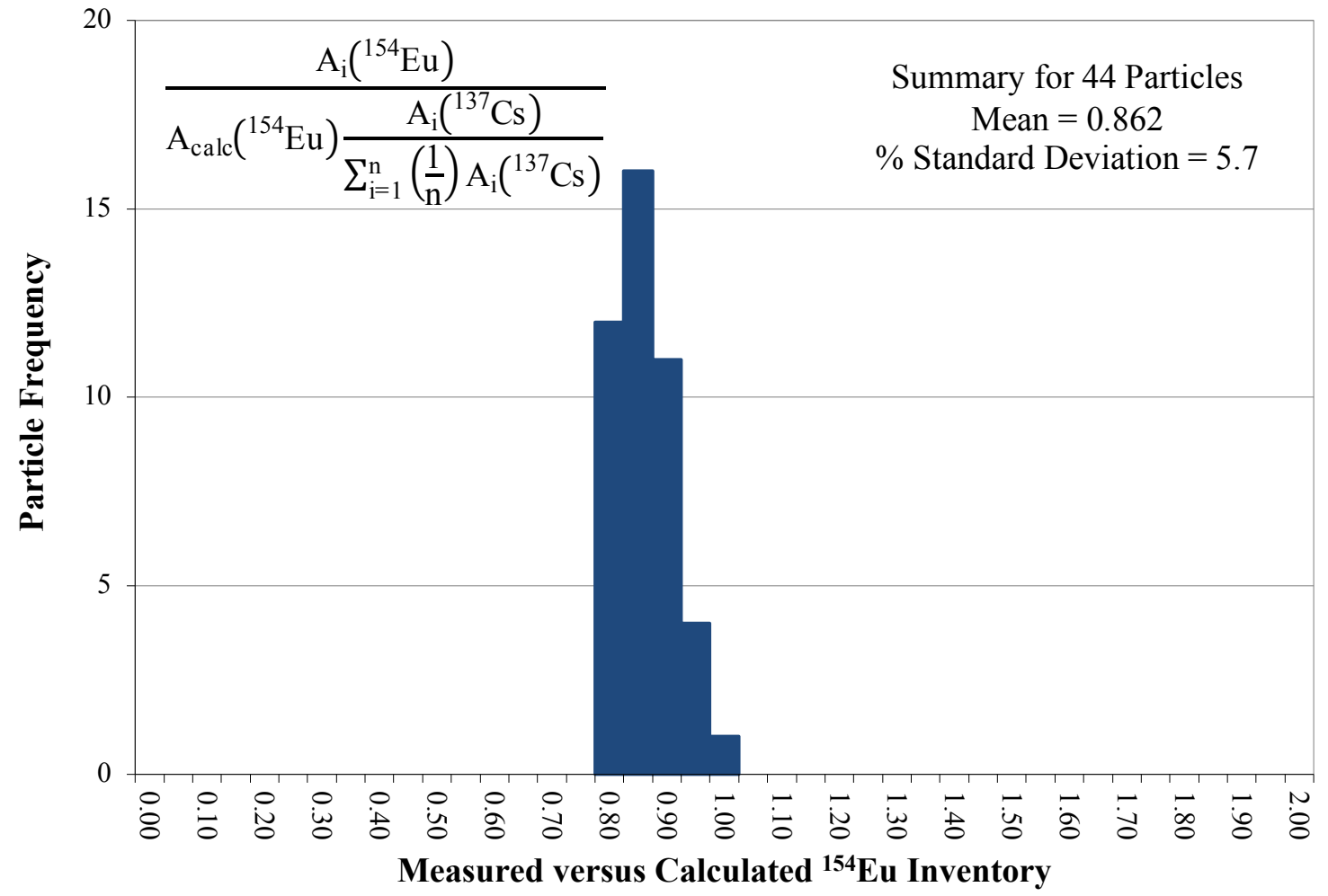

Figure 7. Ratio of ${ }^{154} \mathrm{Eu}$ retained in 44 particles versus the calculated inventory, adjusted for variation in fissionable material and burnup with the measured ${ }^{137} \mathrm{Cs}$ activity. 


\section{MATERIALOGRAPHY}

The four-hour IMGA measurement data in Table 5 were used to select particles for microstructural analyses from various regions of the ${ }^{110 \mathrm{~m}} \mathrm{Ag}$ distribution (Figure 5), with a secondary criterion of wanting other isotope inventories in these particles to be generally close to average. Table 7 lists the particles selected for materialography. The measured versus calculated inventory $(\mathrm{M} / \mathrm{C})$ values in the table were calculated with the same method used for Figure 5-Figure 7. The measured versus average inventory values were calculated similar to the $\mathrm{M} / \mathrm{C}$ values, except the offset in the calculated activity was mostly removed by replacing the calculated activity for each isotope in the equation with the measured average activity for the 44-particle data set, for example

$$
\frac{\mathrm{A}_{\mathrm{i}}\left({ }^{154} \mathrm{Eu}\right)}{\sum_{\mathrm{i}=1}^{\mathrm{n}}\left(\frac{1}{\mathrm{n}}\right) \mathrm{A}_{\mathrm{i}}\left({ }^{154} \mathrm{Eu}\right) \frac{\mathrm{A}_{\mathrm{i}}\left({ }^{137} \mathrm{Cs}\right)}{\sum_{\mathrm{i}=1}^{\mathrm{n}}\left(\frac{1}{\mathrm{n}}\right) \mathrm{A}_{\mathrm{i}}\left({ }^{137} \mathrm{Cs}\right)}} .
$$

This shifted the $\mathrm{M} / \mathrm{C}$ distribution to be essentially-centered around unity, making it easier to survey the results with respect to the average.

Table 7. Particles selected for materialography

\begin{tabular}{|c|c|c|c|c|c|c|c|}
\hline \multicolumn{8}{|c|}{ Measured versus calculated inventory ${ }^{a}$} \\
\hline Particle & ${ }^{106} \mathbf{R u}$ & ${ }^{110 m} \mathrm{Ag}^{c}$ & ${ }^{125} \mathrm{Sb}$ & ${ }^{134} \mathrm{Cs}$ & ${ }^{137} \mathrm{Cs}$ & ${ }^{144} \mathrm{Ce}$ & ${ }^{154} \mathbf{E u}$ \\
\hline 542-RS01 & 1.11 & $<0.18$ & 0.74 & 0.99 & 1.00 & 1.11 & 0.83 \\
\hline 542-RS07 & 1.18 & $<0.18$ & 0.76 & 0.99 & 1.04 & 1.08 & 0.87 \\
\hline 542-RS11 & 1.07 & 0.23 & 0.73 & 0.97 & 1.00 & 1.11 & 0.82 \\
\hline $542-\mathrm{RS} 30$ & 1.06 & 0.32 & 0.73 & 1.00 & 1.06 & 1.05 & 0.84 \\
\hline $542-\mathrm{RS} 25$ & 1.15 & 1.03 & 0.74 & 1.01 & 1.08 & 1.03 & 0.90 \\
\hline $542-\mathrm{RS} 33$ & 1.11 & 1.23 & 0.73 & 1.04 & 1.15 & 0.97 & 0.92 \\
\hline
\end{tabular}

Measured versus average inventory ${ }^{b}$

\begin{tabular}{|c|c|c|c|c|c|c|c|}
\hline Particle & ${ }^{106} \mathrm{Ru}$ & ${ }^{110 \mathrm{~m}} \mathrm{Ag}^{c}$ & ${ }^{125} \mathrm{Sb}$ & ${ }^{134} \mathrm{Cs}$ & ${ }^{137} \mathrm{Cs}$ & ${ }^{144} \mathrm{Ce}$ & ${ }^{154} \mathbf{E u}$ \\
\hline 542-RS01 & 0.98 & $<0.24$ & 1.00 & 0.99 & 0.97 & 1.03 & 0.96 \\
\hline 542-RS07 & 1.04 & $<0.24$ & 1.01 & 0.99 & 1.00 & 1.00 & 1.01 \\
\hline 542-RS11 & 0.94 & 0.31 & 0.98 & 0.98 & 0.97 & 1.03 & 0.95 \\
\hline 542-RS30 & 0.94 & 0.42 & 0.97 & 1.01 & 1.03 & 0.97 & 0.97 \\
\hline 542-RS25 & 1.02 & 1.37 & 0.99 & 1.01 & 1.05 & 0.96 & 1.04 \\
\hline 542-RS33 & 0.97 & 1.64 & 0.97 & 1.04 & 1.11 & 0.90 & 1.07 \\
\hline
\end{tabular}

${ }^{a} \mathrm{M} / \mathrm{C}$ values were adjusted for fissile material and burnup using the normalized ${ }^{137} \mathrm{Cs}$ activity, except for ${ }^{137} \mathrm{Cs}$, which used the normalized ${ }^{144} \mathrm{Ce}$ activity.

${ }^{b}$ Measured versus average activity inventory values were adjusted for fissile material and burnup using the normalized ${ }^{137} \mathrm{Cs}$ activity, except for ${ }^{137} \mathrm{Cs}$, which used the normalized ${ }^{144} \mathrm{Ce}$ activity.

${ }^{c}$ Less than values indicate the ${ }^{110 \mathrm{~m}} \mathrm{Ag}$ activity was below the detection limit.

\subsection{OPTICAL MICROSCOPY}

Particles were mounted and polished to near midplane using the methods and equipment developed for AGR-1 PIE [Hunn et al. 2013a], and polished cross sections were imaged with a Leica DMI5000 optical microscope. Figure 8 shows two bright-field reflected-light optical micrographs of an unirradiated AGR-2 UCO TRISO particle cross section near midplane. The UCO kernel shows the typical mixture of uranium carbide (white regions) and uranium oxide (gray regions) in the center of the kernel, surrounded by a uranium oxide rind and a uranium carbide skin at the surface. The lower-density buffer layer appears darker (less reflection) than the inner pyrocarbon (IPyC) and outer pyrocarbon (OPyC) layers. The $\mathrm{IPyC} / \mathrm{SiC}$ interface shows evidence of the stitching that occurs when the SiC deposition infiltrates the open porosity of the IPyC. The character of the $\mathrm{SiC} / \mathrm{OPyC}$ interface is different because the $\mathrm{SiC}$ surface is non-porous, however the $\mathrm{OPyC}$ does closely replicate the granular surface of the $\mathrm{SiC}$. 


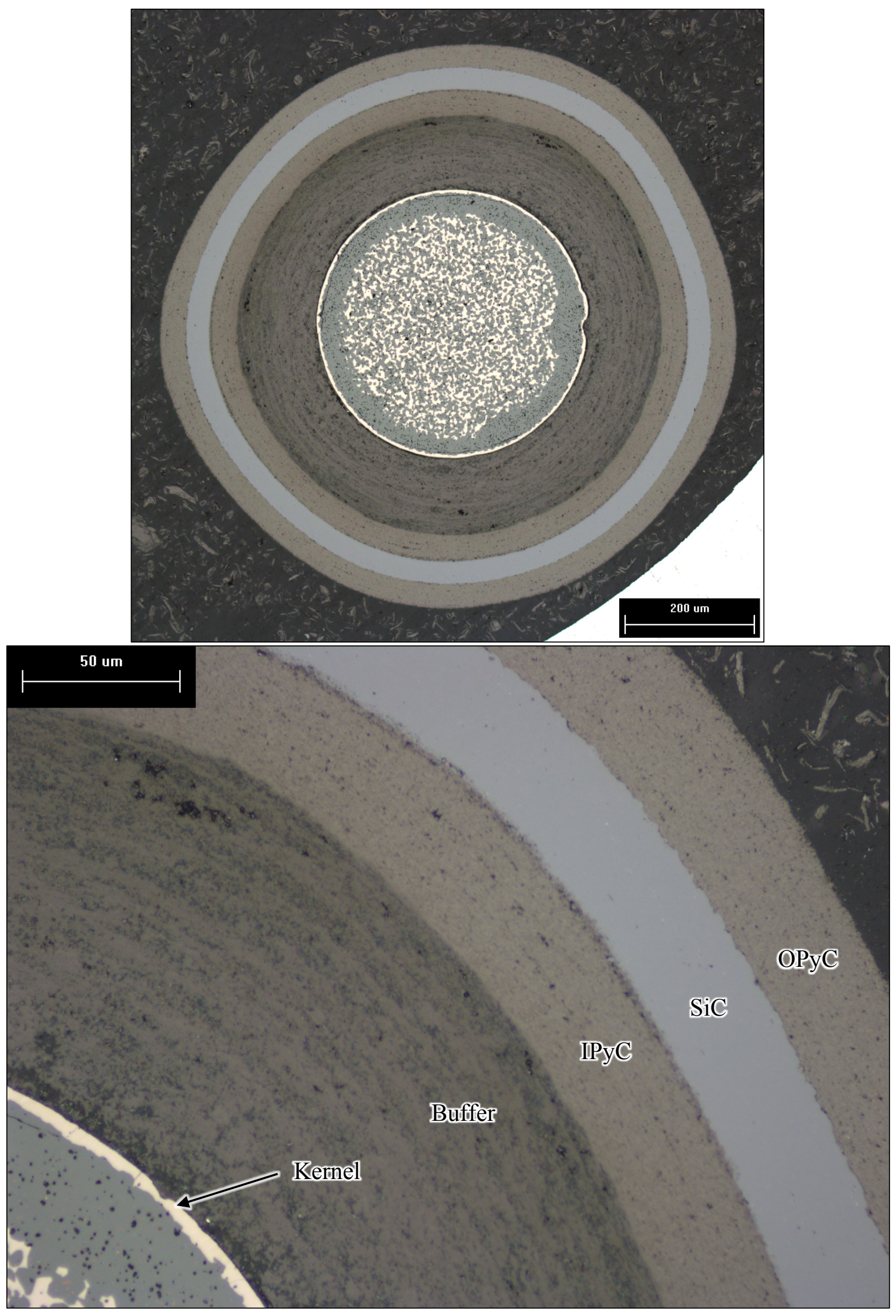

Figure 8. As-fabricated AGR-2 UCO TRISO (LEU09). 
Figure 9-Figure 14 are optical micrographs of the particle cross sections. The quality of the polish was non-optimal due to debris introducing scratches, gouges, and chips in the prepared surfaces. These features should not be mistaken for fabrication or irradiation damage or defects in the coating layers. For instance, several scratches and gouges are visible in the OPyC layer in Figure 9 and there is a chip in the $\mathrm{SiC}$ at the top of the image with foreign material embedded at the $\mathrm{SiC} / \mathrm{OPyC}$ interface. The embedded material probably caused the gouge still visible in the OPyC and epoxy near this feature. As discussed in Section 4.2 and shown in Figure 42, the embedded material had the components of steel. Similar features that appear white in these brightfield reflected-light images can be seen in some of the kernel pores. The fact that these white fragments also appear in the back-potting epoxy in the buffer region further confirm that they are debris introduced during grinding. Some of these spots were analyzed with EDS and were found to be aluminum (a typical contaminant from the sample holder) and zirconium (known to come from another hot cell specimen). The unusual prevalence of scratches and debris in this series of particles is believed to be related to an operational problem that occurred with the thinning attachment during polishing of the specimen immediately prior to the Compact 5-4-2 particles. Some crack-like features visible in Figure 9-Figure 14 cannot, by themselves, be obviously ruled out as grinding artifacts, but conclusions should not be drawn from these images alone.

In general, the as-fabricated and post-irradiation structure and interface characteristics of the outer three layers do not look significantly different when viewed with the optical microscope. In contrast, significant radiation-induced changes are evident in the kernel and buffer, as is typical for all AGR irradiation test particles. Buffer fracture occurred in five of the six particles in Table 7. Asymmetric swelling of the kernel resulted in protrusion of kernel material into the gaps between buffer fragments. The reduced swelling constraint for kernels in particles with fractured buffer also resulted in larger pores in comparison to Particle 542-RS33 (Figure 14), whose buffer remained intact. Note that material with a uniform gray appearance in between buffer fragments and in the buffer/IPyC gap is epoxy added to backfill this space during grinding. When these gap regions appear black, this indicates that the backfill epoxy was unable to fill that space. Similarly, revealed pores in the kernel often appear black.

To obtain better statistics on the buffer and kernel behavior, a single materialographic mount of 29 randomly-selected particles was prepared. Figure 15 is a compilation of individual images of each particle in the mount. Buffer fracture was apparent in 22 of the 29 particles.

Most particles showed a distinct interface layer between the main regions of the buffer and the kernel (e.g., Figure 9), This region appeared denser and less porous than the bulk of the buffer layer. Sometimes the region was attached to the kernel and separated from the buffer, while sometime this was reversed; Figure 12 shows a particle where both are evident. Section 4.2 includes a discussion of the EDS analysis of this region in Particle 542-RS01 that revealed uranium and other fission products dispersed throughout (see discussion of Figure 43 in that section). EDS analysis was also performed to examine the buffercolored spots identified in Figure 9 (see discussion of Figure 45 in Section 4.2). 


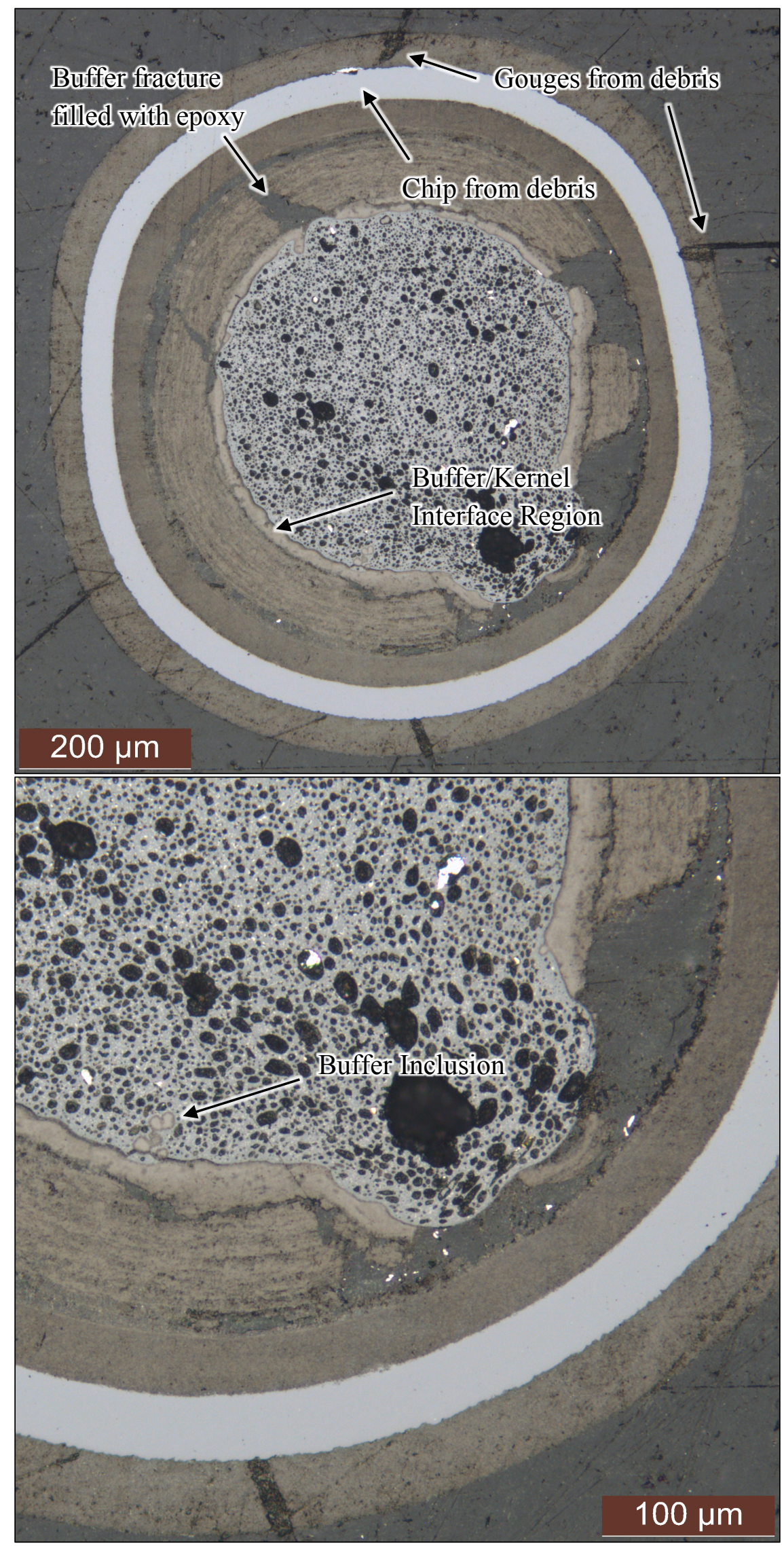

Figure 9. Particle 542-RS01 near midplane. 

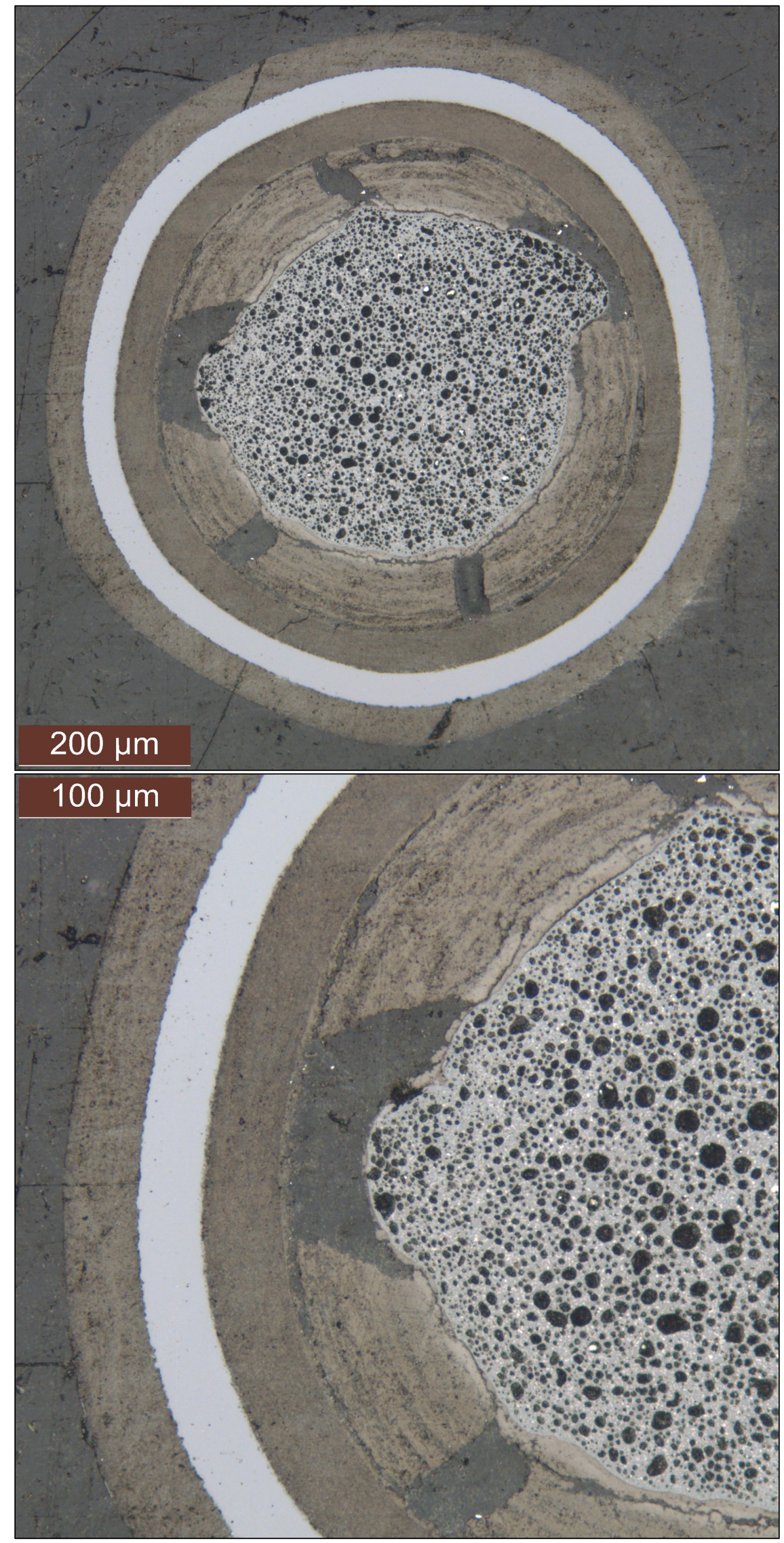

Figure 10. Particle 542-RS07 near midplane. 


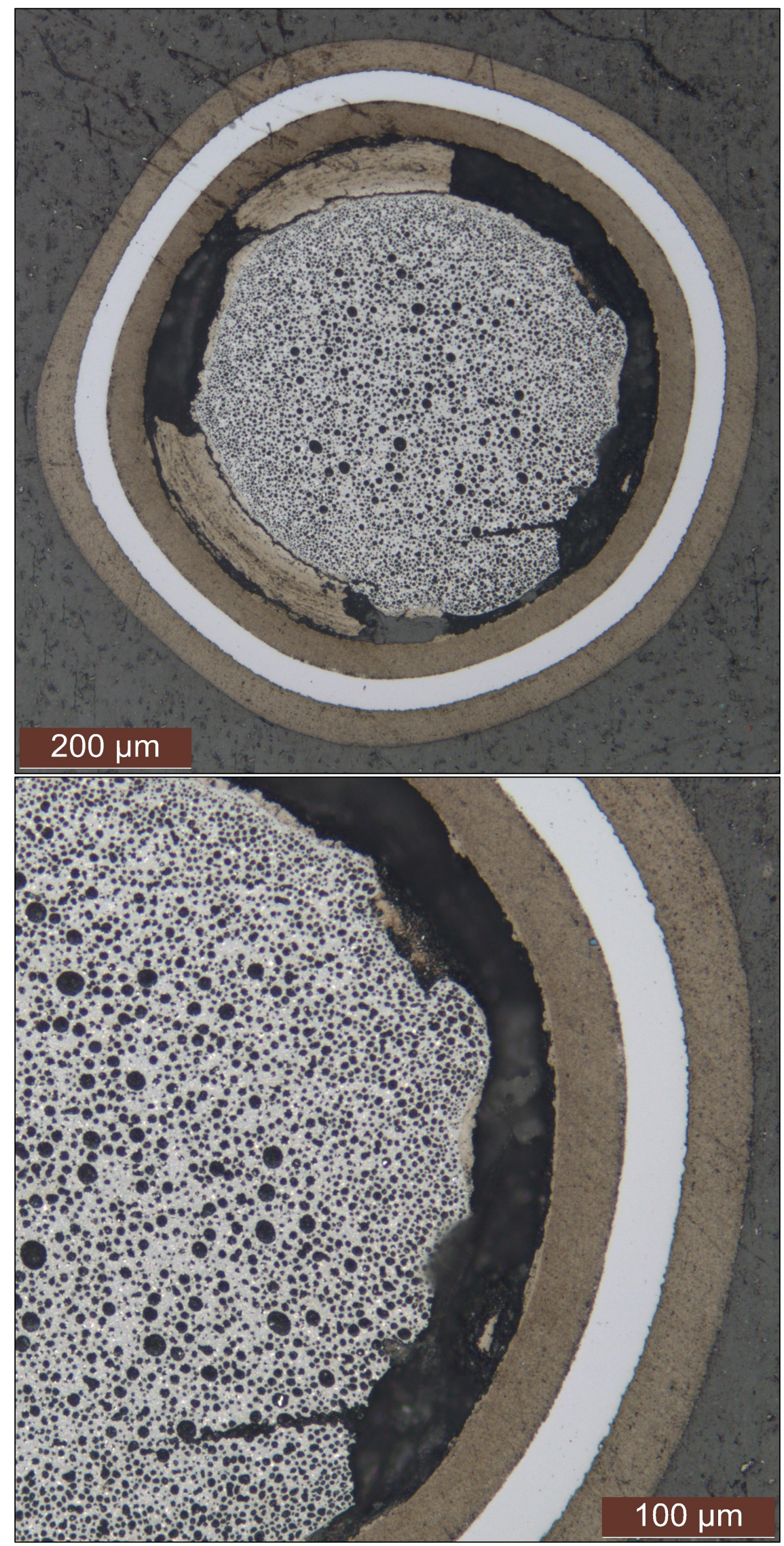

Figure 11. Particle 542-RS11 near midplane. 

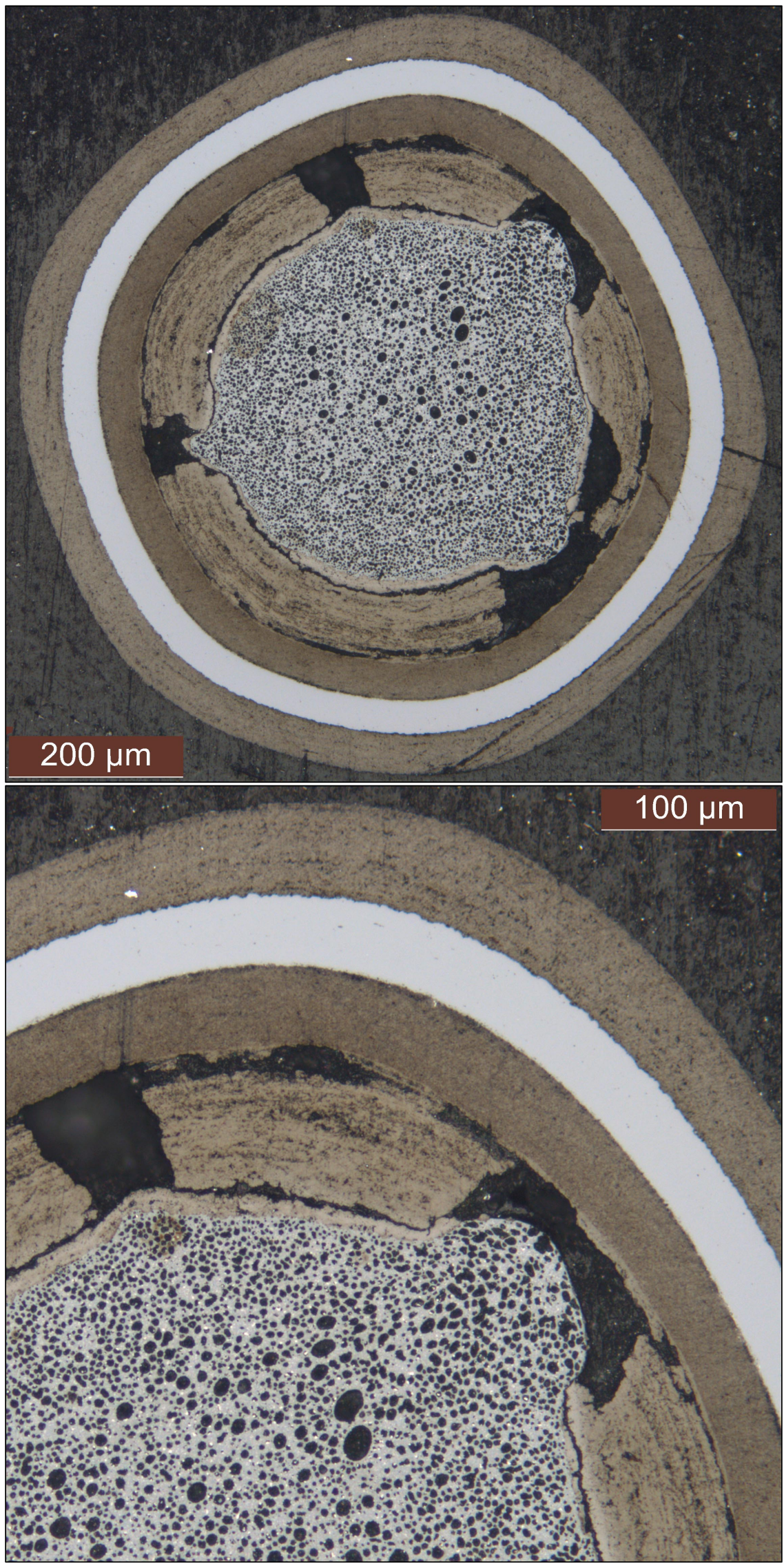

Figure 12. Particle 542-RS30 near midplane. 


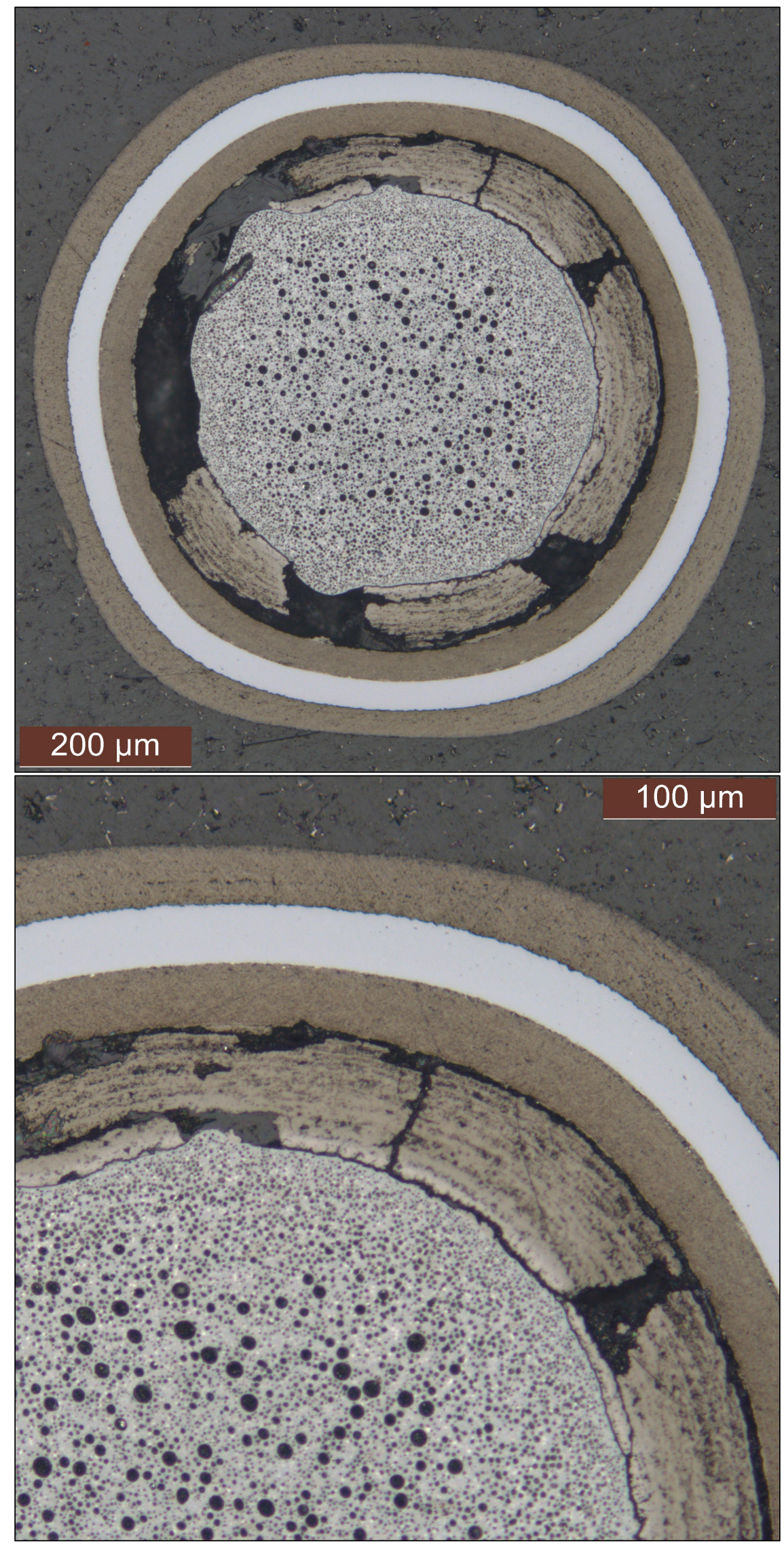

Figure 13. Particle 542-RS25 near midplane. 


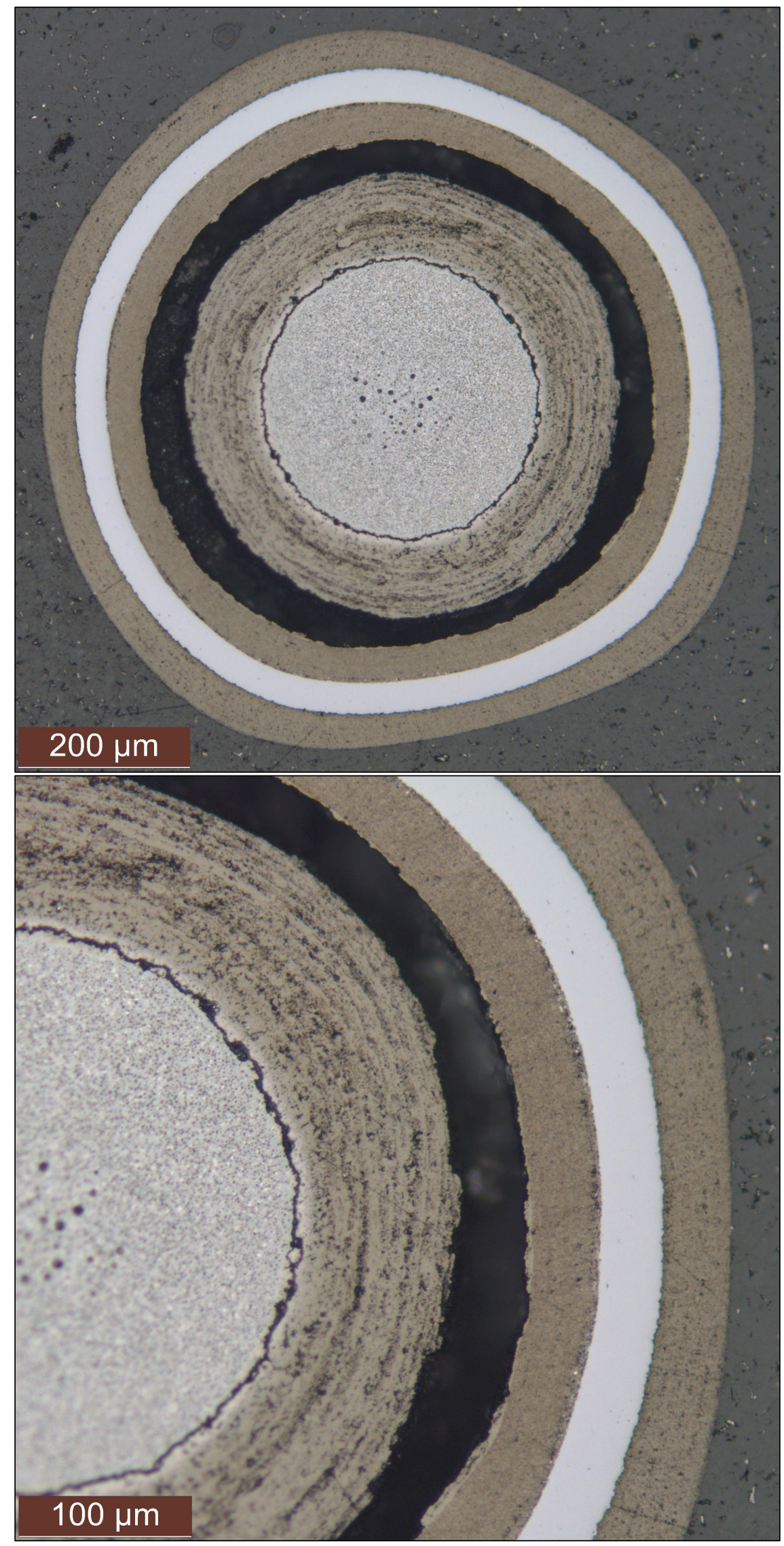

Figure 14. Particle 542-RS33 near midplane. 


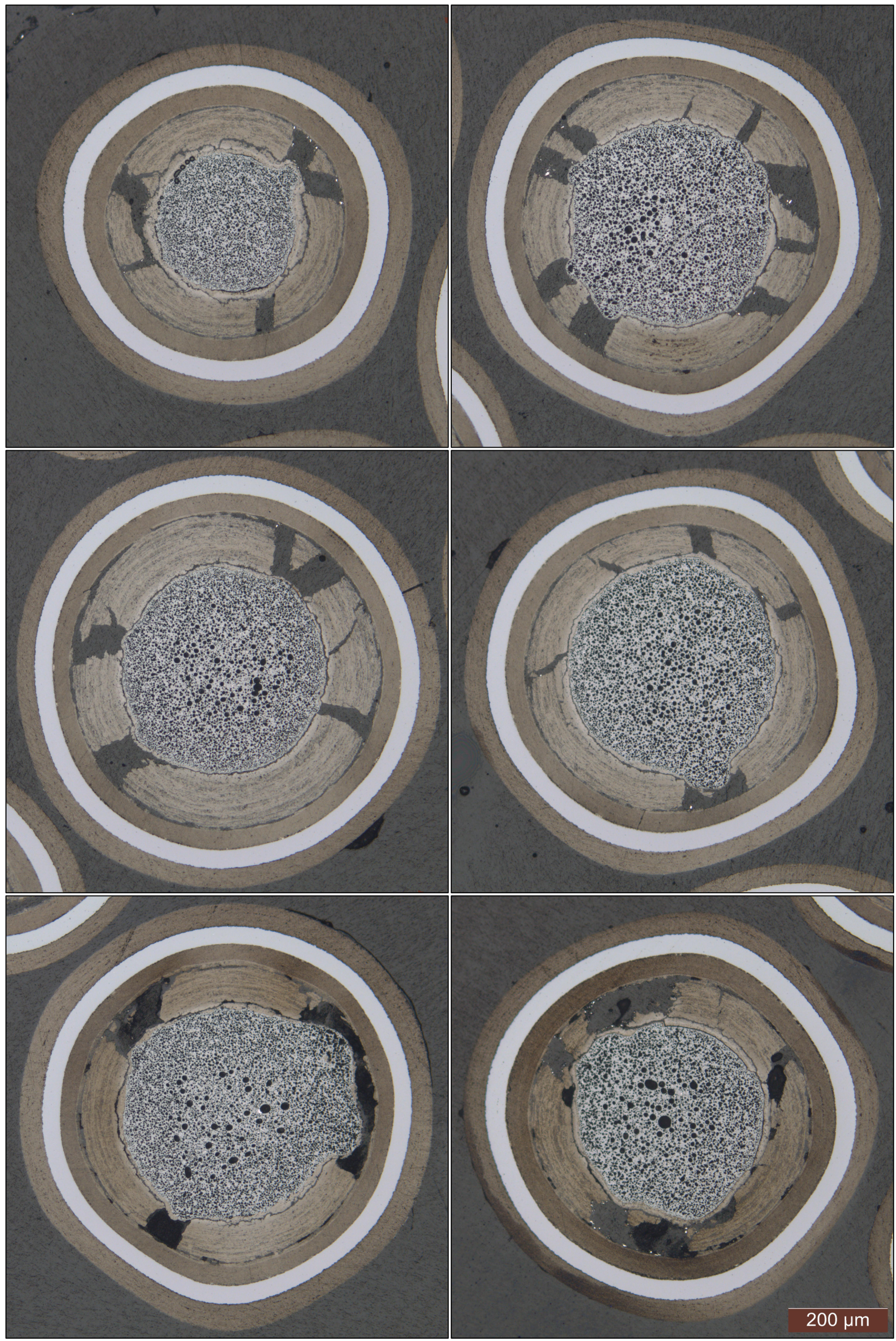

Figure 15. Images of randomly-selected particles from multiparticle mount MM-E07. 


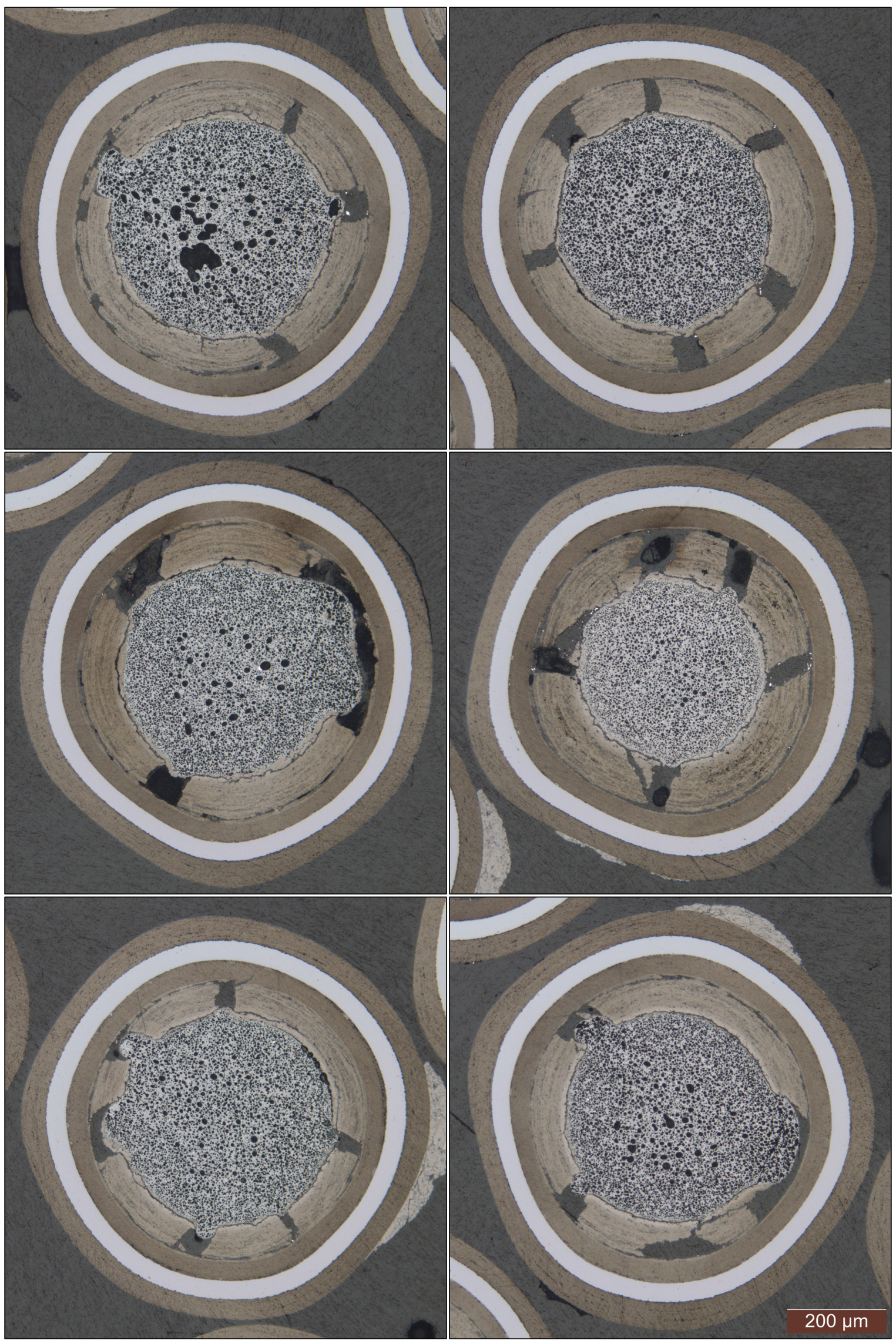

Figure 15 (continued). Images of randomly-selected particles from multiparticle mount MM-E07. 

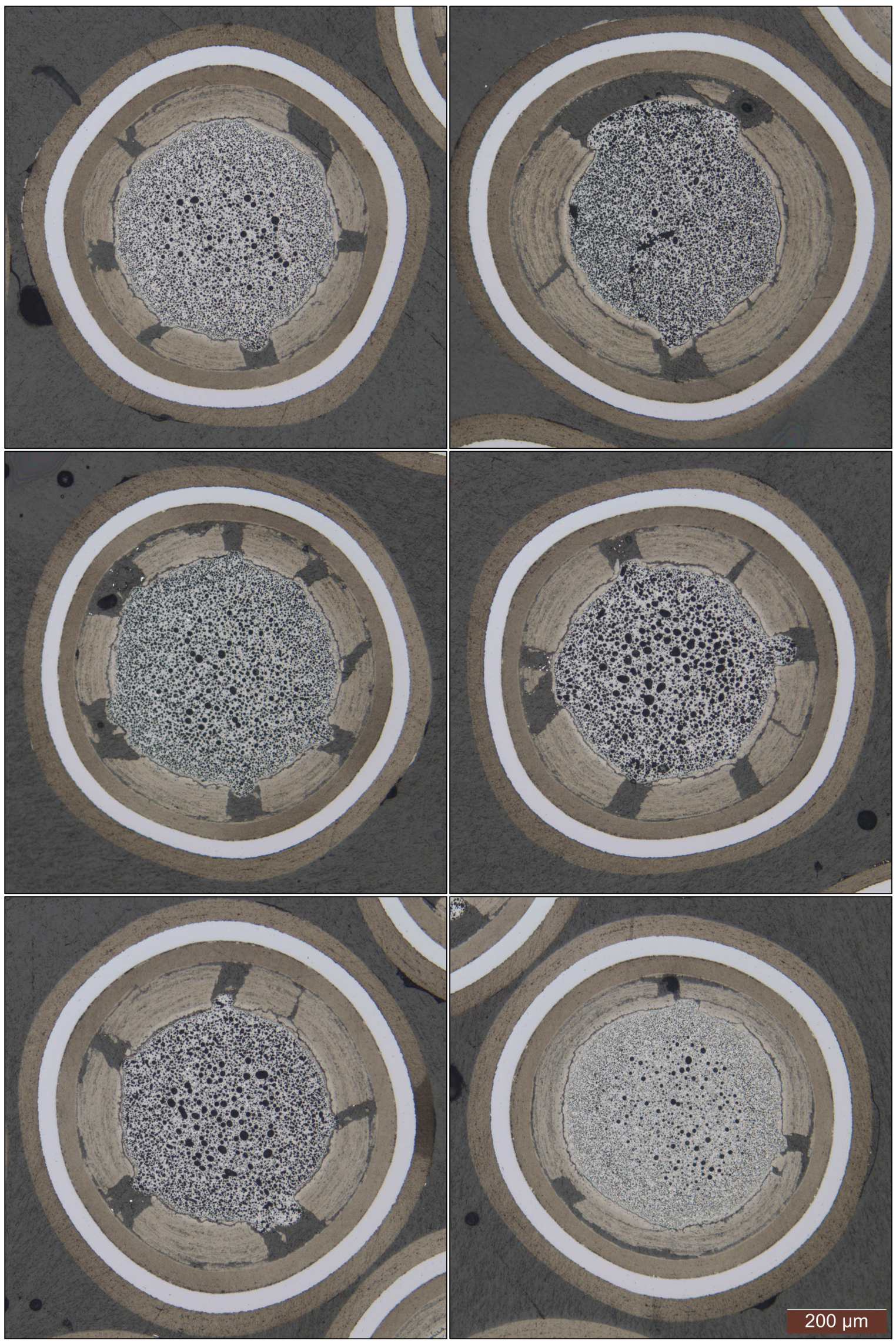

Figure 15 (continued). Images of randomly-selected particles from multiparticle mount MM-E07. 

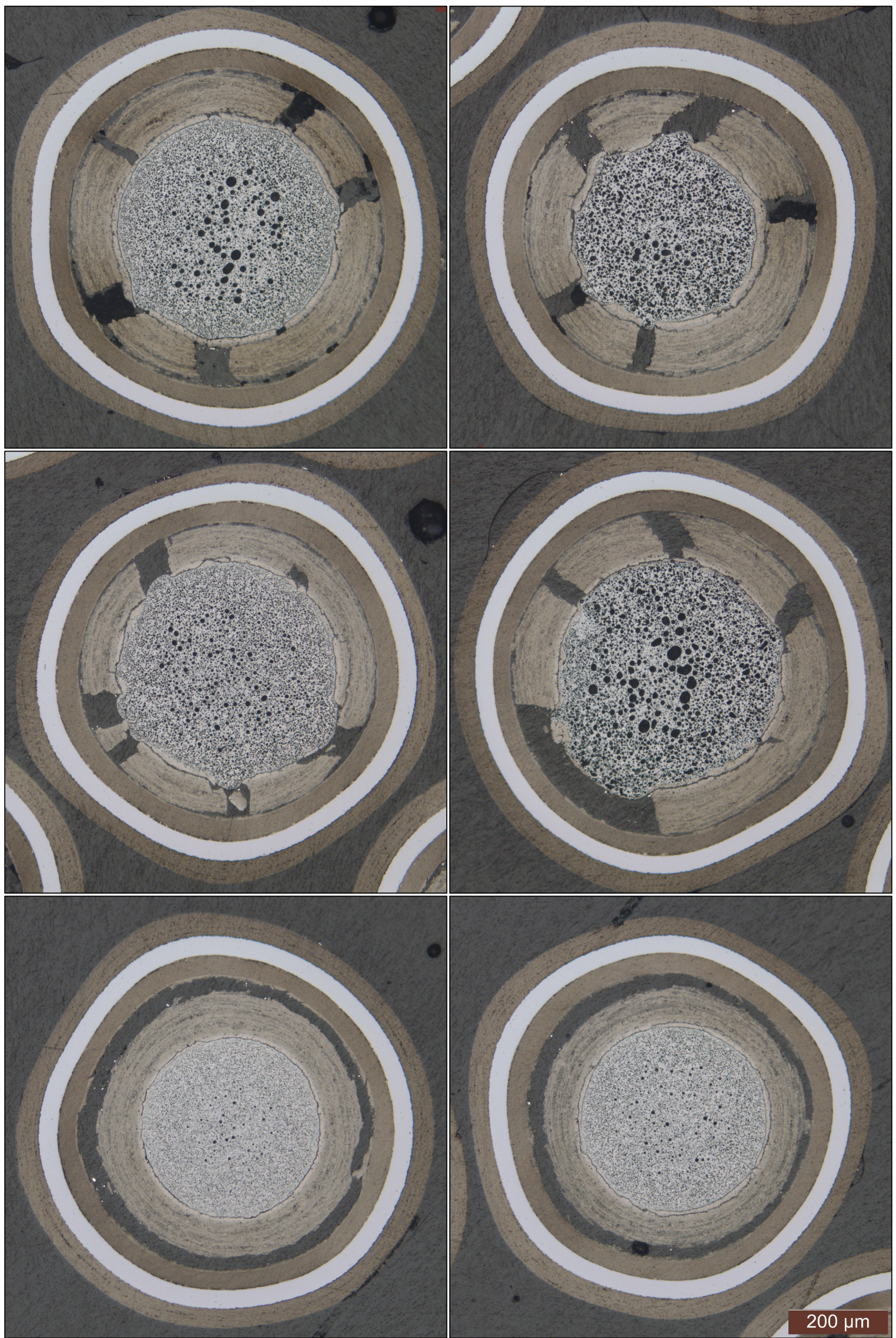

Figure 15 (continued). Images of randomly-selected particles from multiparticle mount MM-E07. 

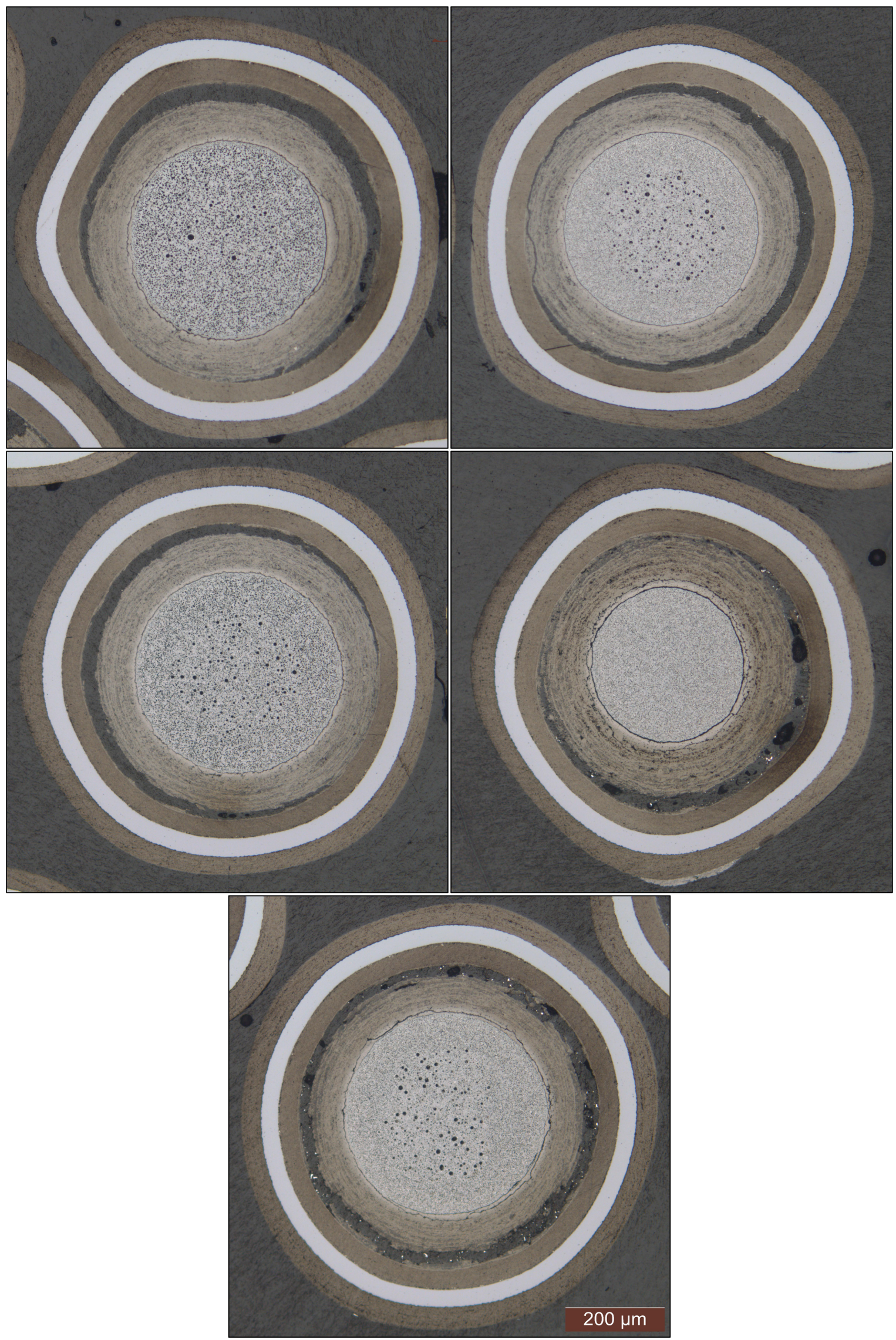

Figure 15 (continued). Images of randomly-selected particles from multiparticle mount MM-E07. 


\subsection{SCANNING ELECTRON MICROSCOPY}

Analysis was performed with a JEOL JSM-6390L SEM equipped with an Oxford X-Max 50 silicon drift detector and Oxford AZtec analysis software suite for EDS. The SEM is located in a contamination control area in Room 120 of the ORNL IFEL hot cells. The SEM analysis was performed on the mounts previously imaged by optical microscopy (Table 7). To facilitate analysis, the mounts were transferred out of the hot cell to the IFEL charging area where initial decontamination was performed to reduce radiological contamination. The mounts were then transferred to a radiological hood located in Room 120 for final radiological decontamination and surface cleaning. The mounts were subjected to ultrasonic cleaning in deionized water, rinsed with isopropyl alcohol, and cleaning with a cotton swab. This cleaning and decontamination process was repeated three times. Following decontamination, the samples were smeared and surveyed for release from the hood. After release from the hood, the sample surfaces were checked by an optical microscope located in the contamination control area. If the sample surfaces were free of significant debris the samples were mounted on an aluminum SEM stub using conductive carbon tape and colloidal graphite to secure the sample and facilitate SEM analysis.

Two SEM imaging modes were performed in concert. The two modes included secondary electron (SE) imaging and backscattered-electron composition (BEC) imaging. The two modes were utilized as they provide different information on the particle cross-sections. The SE signal is surface sensitive which allows for surface features and any irregularities to be identified. The SE images were obtained using a $3-\mathrm{kV}$ accelerating voltage, spot size of 40 (a unitless value), and working distance of $8 \mathrm{~mm}$. The BEC signal is dependent on the atomic number $(Z)$ of the elements near the surface. This allows for high- $Z$ fission products embedded in the relatively low-Z TRISO layers (IPyC and $\mathrm{SiC}$ ) to be readily identified, because they appear as bright spots. The BEC images were obtained using a $20-\mathrm{kV}$ accelerating voltage, spot size of 64, and working distance of $10 \mathrm{~mm}$. Image pairs of the same areas were acquired using both imaging modes to ensure surface features (such as loose debris) were not misinterpreted as embedded fission products. A general image set was taken for each particle cross-section. The image set consisted of particle overview images, low magnification $(500 \mathrm{x})$ images of the TRISO layers in four cardinal directions, and higher magnification (1500x) images of the SiC layer in four cardinal and inter-cardinal directions around the circumference of the particle. Additional images of select areas of interest were also acquired when necessary. Select images of each examined particle are presented in this section. A minimum of two locations on each particle cross-section were chosen for EDS. The EDS analysis provides insight on the local chemistry (e.g., isolated fission product features), which is required to better understand the distribution of fission products in the TRISO layers after irradiation and safety testing. Point-ID analysis was commonly utilized to identify local compositions. The Point-ID analysis was acquired using the same conditions as BEC imaging mode, which resulted in a sufficient count rate. The general acquisition parameters used for Point-ID analysis were an energy range of 0-20 keV, $10 \mathrm{eV} /$ channel, 4096 channels, a process time of 2 (a unitless quantity), and a 30-second live-time.

Particles with different ${ }^{110 \mathrm{~m}} \mathrm{Ag}$ retention behavior were selected for SEM analysis as the silver retention behavior is a unique performance indicator among individual particles deconsolidated from a single compact. As discussed in Section 4, Table 7 lists the particles retained inventory fraction in terms of ${ }^{110 \mathrm{~m}} \mathrm{Ag} \mathrm{M} / \mathrm{C}$ inventory. Prior PIE analysis has shown intact particles that released silver and those that retained silver exhibited different distributions of fission products in the TRISO layers [Hunn et al. 2012; Hunn et al. 2013b; Hunn et al. 2014a; Hunn et al. 2014b; Hunn et al. 2014c]. Particles selected from Compact 5-4-2 can be categorized by three different silver inventory levels: lowest-silver (542-RS01 with ${ }^{110 \mathrm{~m}} \mathrm{Ag} \mathrm{M} / \mathrm{C}<0.18$ and 542-RS07 with ${ }^{110 \mathrm{~m}} \mathrm{Ag} \mathrm{M} / \mathrm{C}<0.18$ ), low-silver (542-RS11 with

${ }^{110 \mathrm{~m}} \mathrm{Ag} \mathrm{M} / \mathrm{C}=0.23$ and 542-RS30 with ${ }^{110 \mathrm{~m}} \mathrm{Ag} \mathrm{M} / \mathrm{C}=0.32$ ), and high-silver (542-RS25 with ${ }^{110 \mathrm{~m}} \mathrm{Ag} \mathrm{M} / \mathrm{C}=1.03$ and $542-\mathrm{RS} 33$ with ${ }^{110 \mathrm{~m}} \mathrm{Ag} \mathrm{M} / \mathrm{C}=1.23$ ). The lowest-silver particles had ${ }^{110 \mathrm{~m}} \mathrm{Ag}$ inventories below the limits of detection for the IMGA four-hour counts and can be confidently presumed to have released a majority of their silver inventory. Likewise, the high-silver particles are another bounding condition and can be confidently presumed to have retained a majority of their silver inventory. 
All particles in the TRISO layer overview micrographs shown in Figure 16-Figure 21 exhibited isolated, micron-scale, high- $\mathrm{Z}$ pileup features at the $\mathrm{IPyC} / \mathrm{SiC}$ interface that were scattered around the visible circumference. These common features varied in size, intensity, and distance from the SiC layer. A comparison of the pileup features in the imaged cross sections of Particle 542-RS07 (Figure 17) and Particle 542-RS25 (Figure 20) highlights the observed differences among the particles. In Particle 542-RS07, the features were diffuse and often positioned further out into the IPyC layer, while the features noted in Particle 542-RS25 appeared with a higher intensity and closer to the SiC layer. This could be related to variability in the width of the interface region, where differences in the IPyC open porosity can affect the depth of $\mathrm{SiC}$ infiltration.

A clear difference in high- $Z$ feature distribution (bright spots) within the $\mathrm{SiC}$ layer was noted between the lowest-silver particles and the high-silver particles. High- $Z$ features were observed across the entire thickness of the lowest-silver particles (Figure 16 and Figure 17). The low-silver particles indicated isolated high- $\mathrm{Z}$ features present in the $\mathrm{SiC}$ layer (Figure 18 and Figure 19), but the intensity and frequency were apparently diminished relative to the lowest-silver particles. The large feature observed at the $\mathrm{SiC} / \mathrm{OPyC}$ interface in Particle 542-RS01 (Figure 16) is anomalous and was determined to be composed of iron and chromium (see EDS spectra in Figure 42), probably from steel polishing debris transferred to the interface during sample preparation.

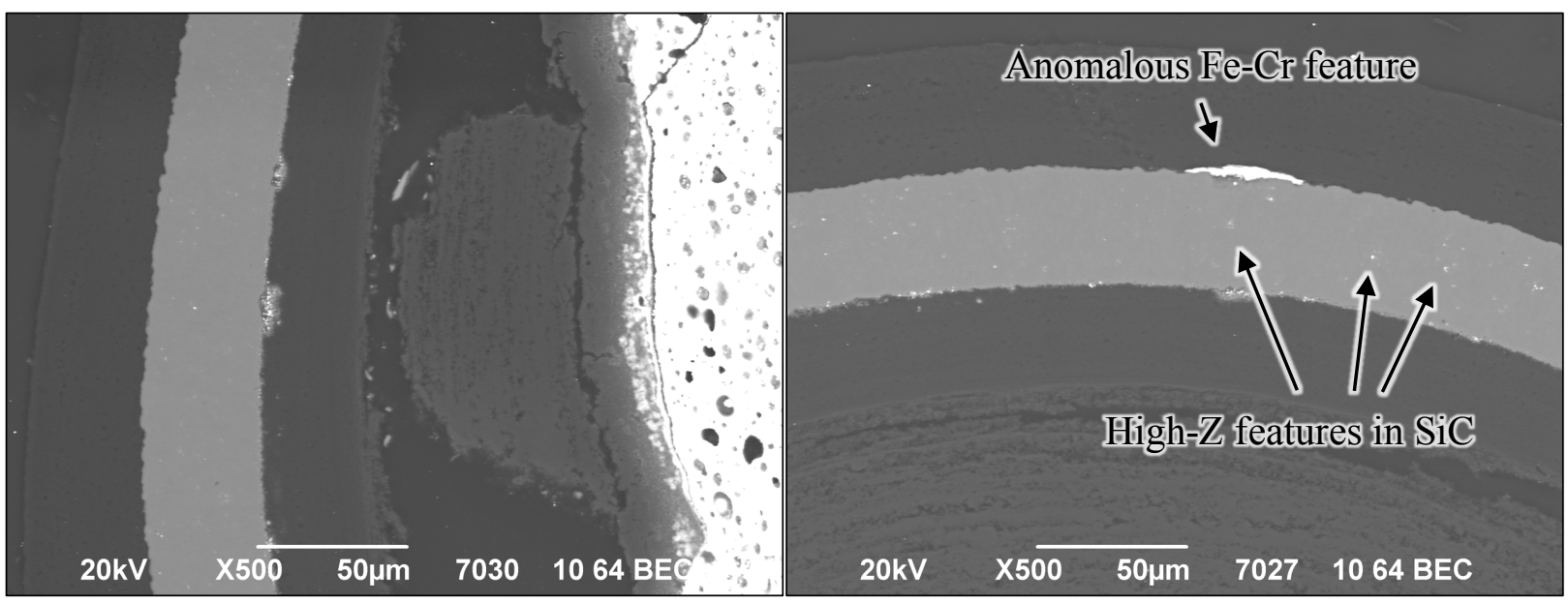

Figure 16. Two 500x BEC images of Particle 542-RS01 with ${ }^{110 \mathrm{~m}} \mathrm{Ag} \mathrm{M} / \mathrm{C}<0.18$.

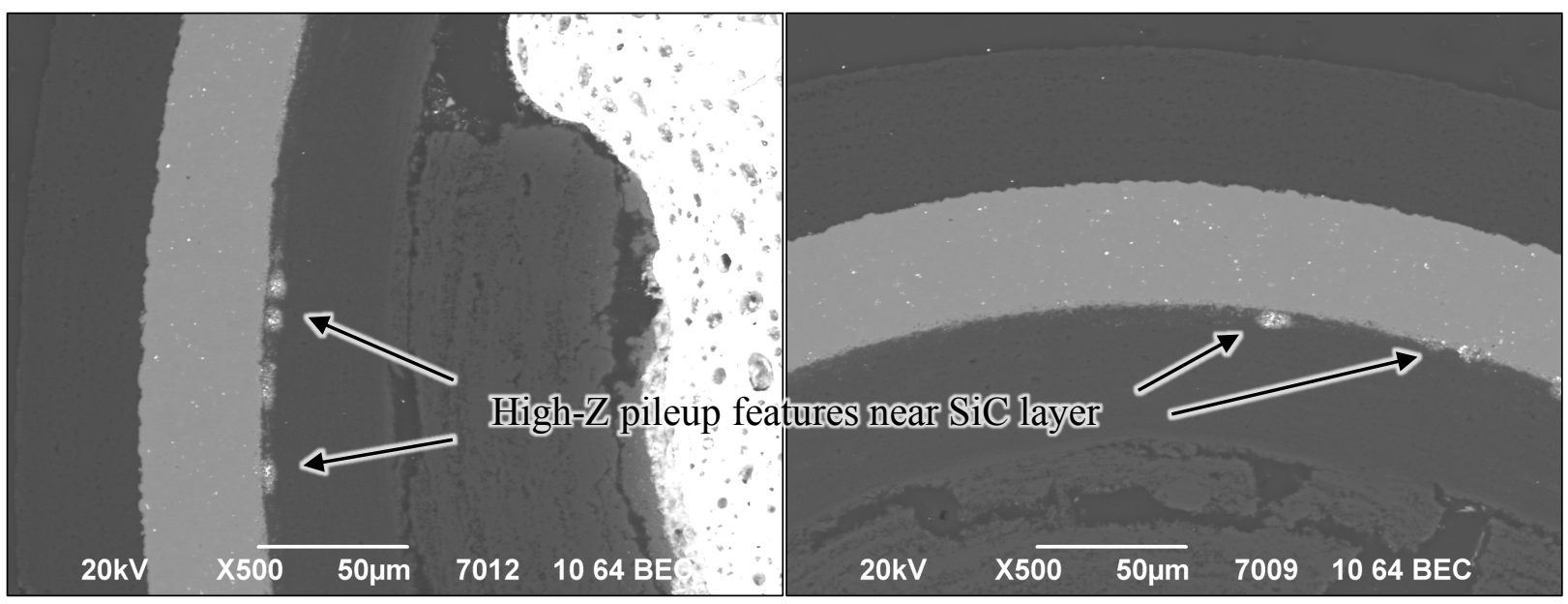

Figure 17. Two 500x BEC images of Particle 542-RS07 with ${ }^{110 \mathrm{~m}} \mathrm{Ag} \mathrm{M} / \mathrm{C}<0.18$. 


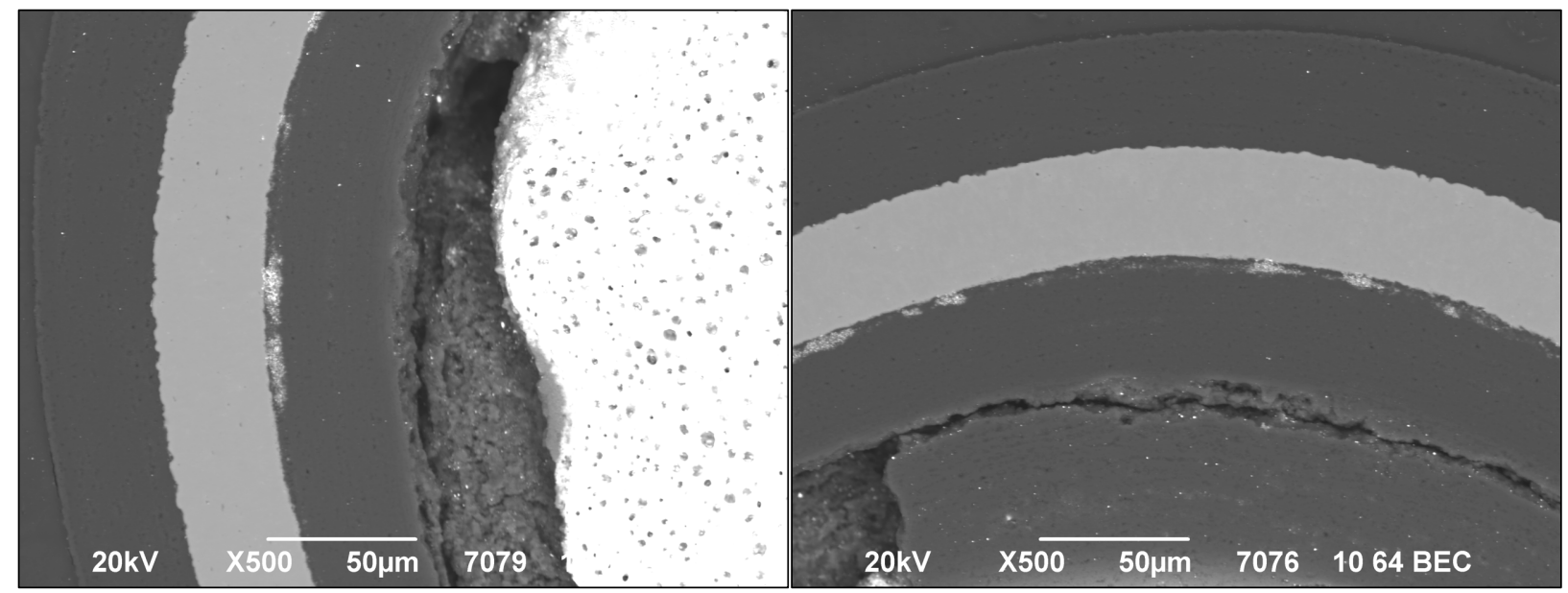

Figure 18. Two 500x BEC images of Particle 542-RS11 with ${ }^{110 \mathrm{~m}} \mathrm{Ag} \mathrm{M} / \mathrm{C}=\mathbf{0 . 2 3}$.

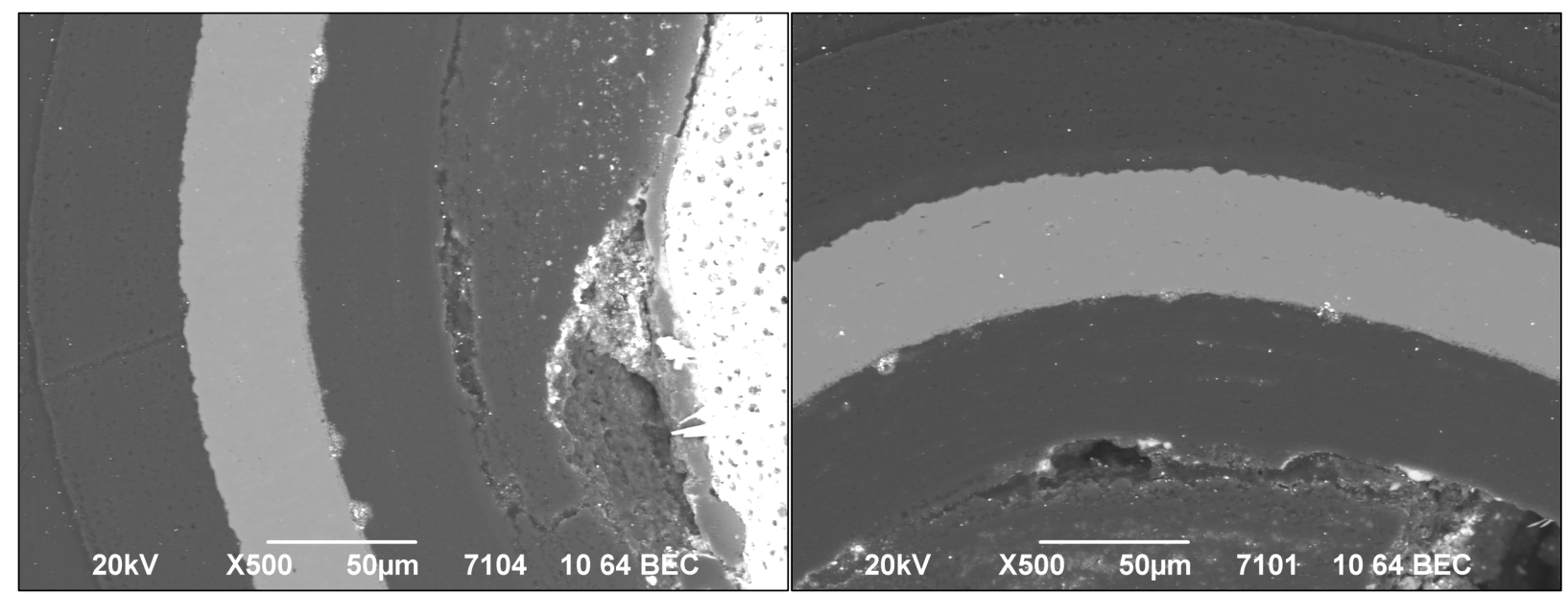

Figure 19. Two 500x BEC images of Particle 542-RS30 with ${ }^{110 \mathrm{~m}} \mathrm{Ag} \mathrm{M} / \mathrm{C}=0.32$.

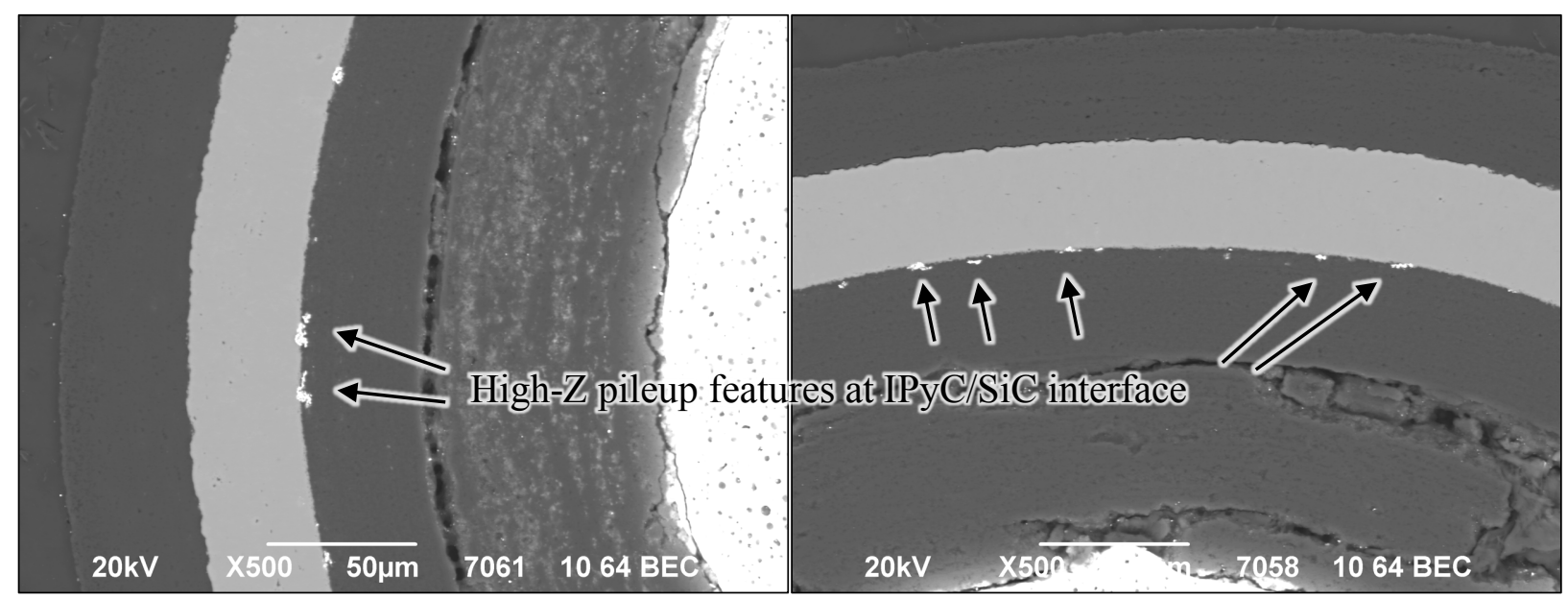

Figure 20. Two 500x BEC images of Particle 542-RS25 with ${ }^{110 \mathrm{~m}} \mathrm{Ag} \mathrm{M} / \mathrm{C}=1.03$. 


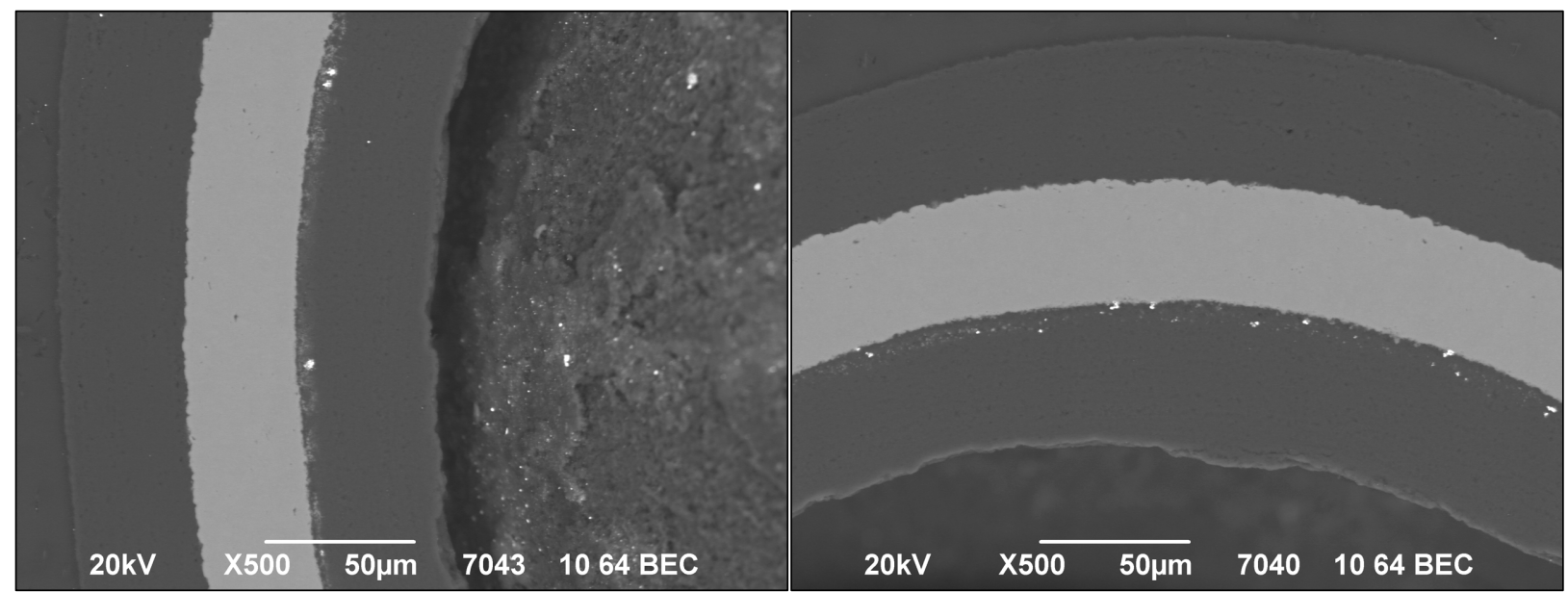

Figure 21. Two 500x BEC images of Particle 542-RS33 with ${ }^{110 \mathrm{~m}} \mathrm{Ag} \mathrm{M} / \mathrm{C}=1.23$.

Figure 22 shows a comparison of the high-Z feature distribution in the IPyC/SiC layer for lowest-silver Particle 542-RS01 $\left({ }^{110 \mathrm{~m}} \mathrm{Ag} \mathrm{M} / \mathrm{C}<0.18\right)$. Surface debris features are distinguishable from embedded features based on shadowing effects and lack of observation in BEC imaging mode. The higher magnification imaging (relative to Figure 16) confirmed that there were embedded high- $Z$ features across the entire $\mathrm{SiC}$ layer and high- $\mathrm{Z}$ pileup features at the $\mathrm{IPyC} / \mathrm{SiC}$ interface.

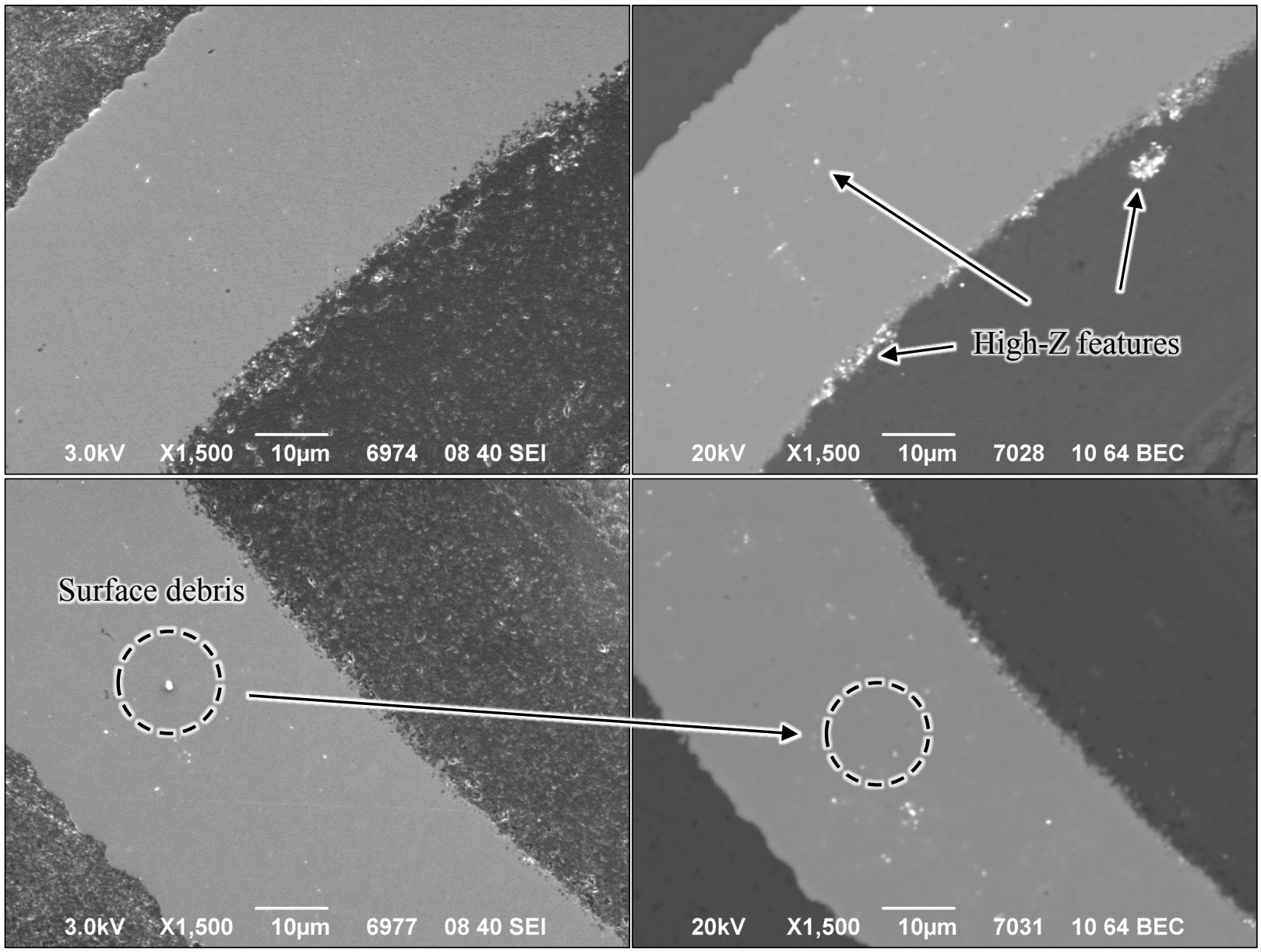

Figure 22. Comparision of SE and BEC image pairs of lowest-silver Particle 542-RS01 $\left({ }^{110 m} \mathrm{Ag} \mathrm{M} / \mathrm{C}<0.18\right)$ showing embedded high-Z features across $\mathrm{SiC}$ layer and differentiation of surface debris from embedded high-Z features. 
Figure 23-Figure 28 show SEM micrographs of the IPyC/SiC layers from all imaged Compact 5-4-2 particles. These micrographs are a higher magnification than the overview images presented in Figure 16Figure 21, and the higher magnification images confirm the suggest trends. The primary observation is that there is a trend in the distribution of high- $Z$ features in the $\mathrm{SiC}$ layer for particles with varying ${ }^{110 \mathrm{~m}} \mathrm{Ag}$ retention. The lowest-silver particles (Figure 23 and Figure 24) exhibited numerous distinct, bright, high- $\mathrm{Z}$ features across the entire thickness of the $\mathrm{SiC}$ layer. The low-silver particles (Figure 25 and Figure 26) also exhibited numerous high- $Z$ features across the entire thickness of the $\mathrm{SiC}$ layer, but the number density, BEC intensity, and apparent size were less than what was observed for the lowest-silver particles. The high-silver particles (Figure 27 and Figure 28) were in stark contrast to the lowest-silver particles as they showed no measurable high- $\mathrm{Z}$ features in the $\mathrm{SiC}$ layer.

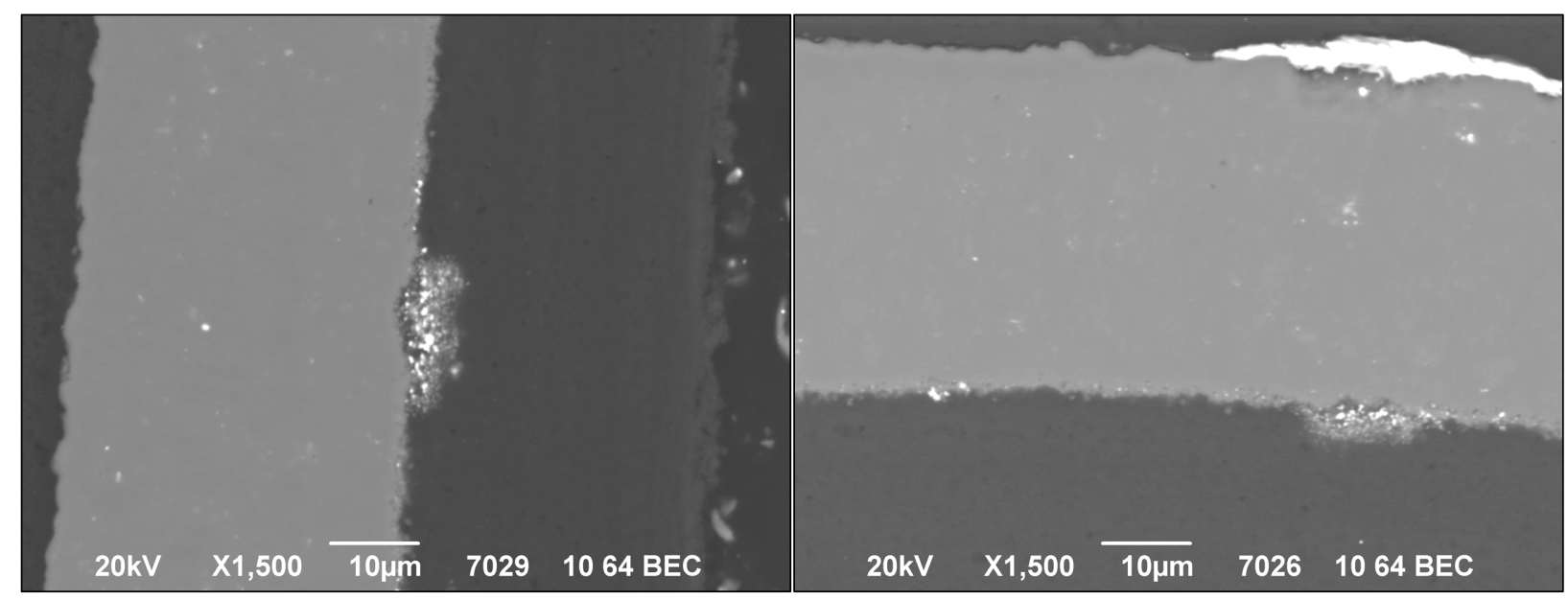

Figure 23. Two 1500x BEC images of Particle 542-RS01 with ${ }^{110 \mathrm{~m}} \mathrm{Ag} \mathrm{M} / \mathrm{C}<0.18$.

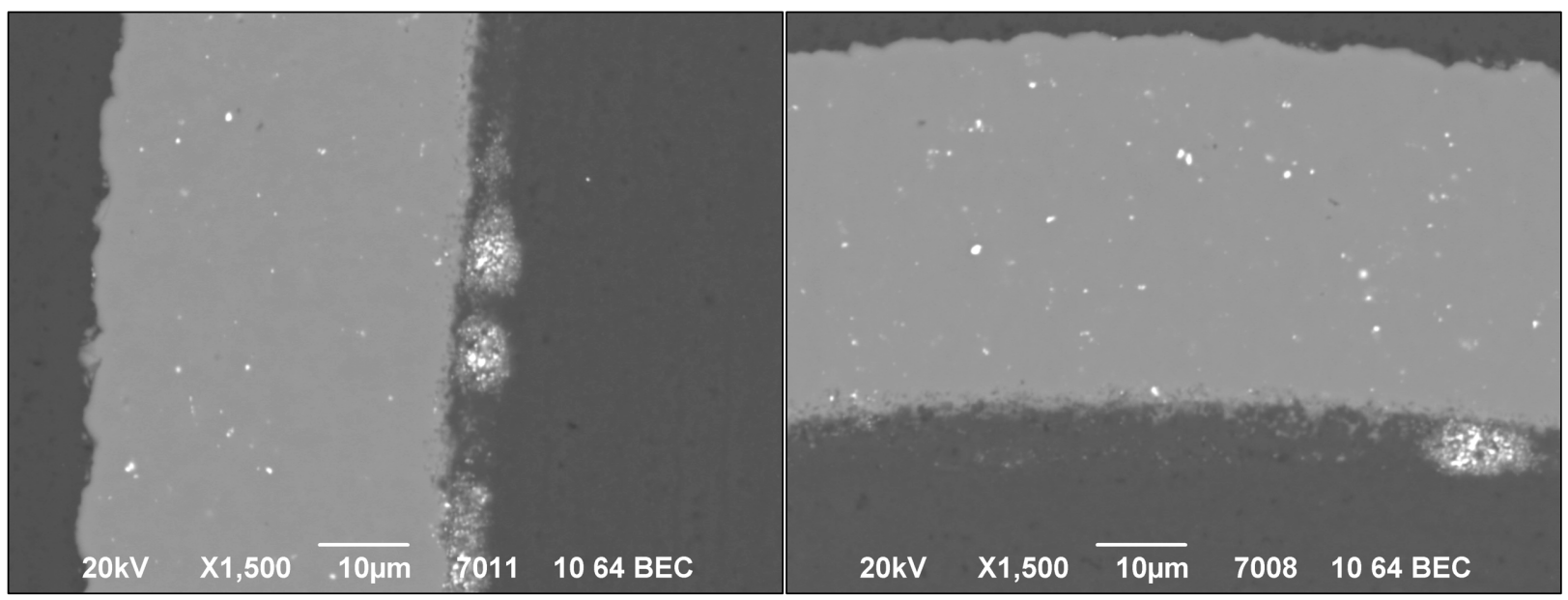

Figure 24. Two 1500x BEC images of Particle 542-RS07 with ${ }^{110 \mathrm{~m}} \mathrm{Ag} \mathrm{M} / \mathrm{C}<0.18$. 


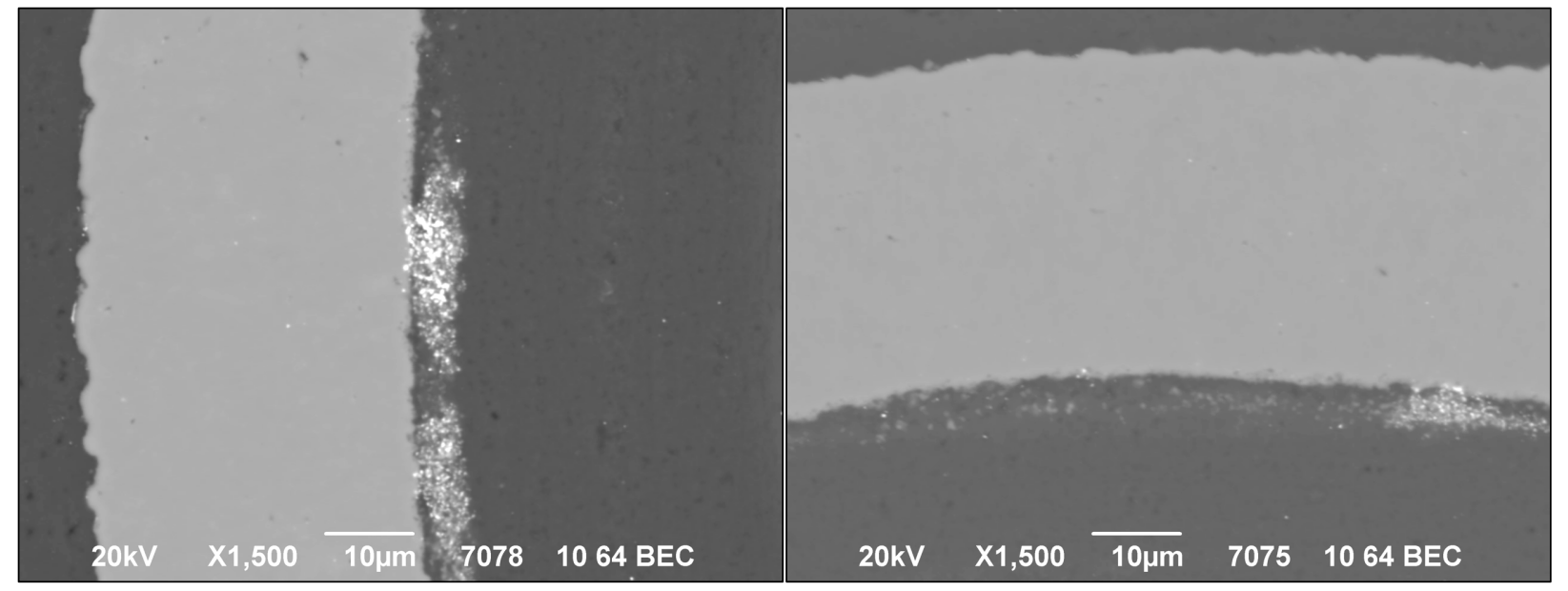

Figure 25. Two 1500x BEC images of Particle 542-RS11 with ${ }^{110 \mathrm{~m}} \mathrm{Ag} \mathrm{M} / \mathrm{C}=0.23$.

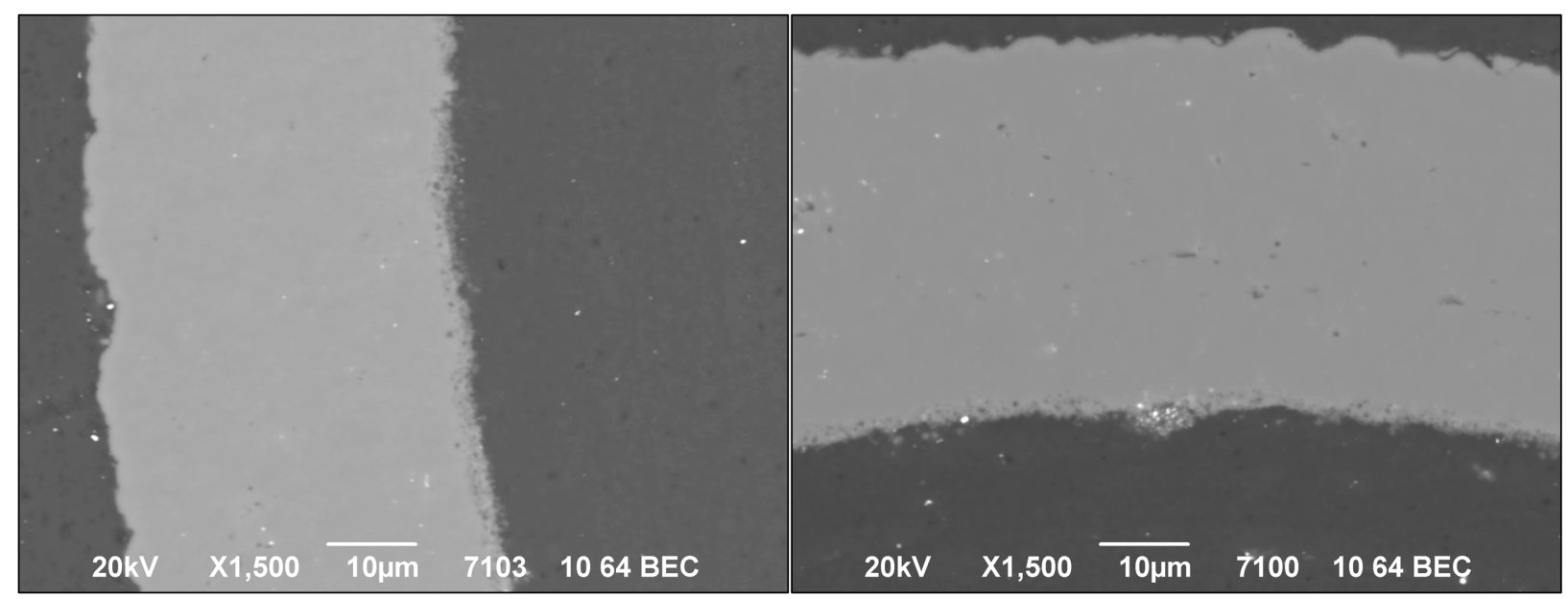

Figure 26. Two 1500x BEC images of Particle 542-RS30 with ${ }^{110 \mathrm{~m}} \mathrm{Ag} \mathrm{M} / \mathrm{C}=0.32$.

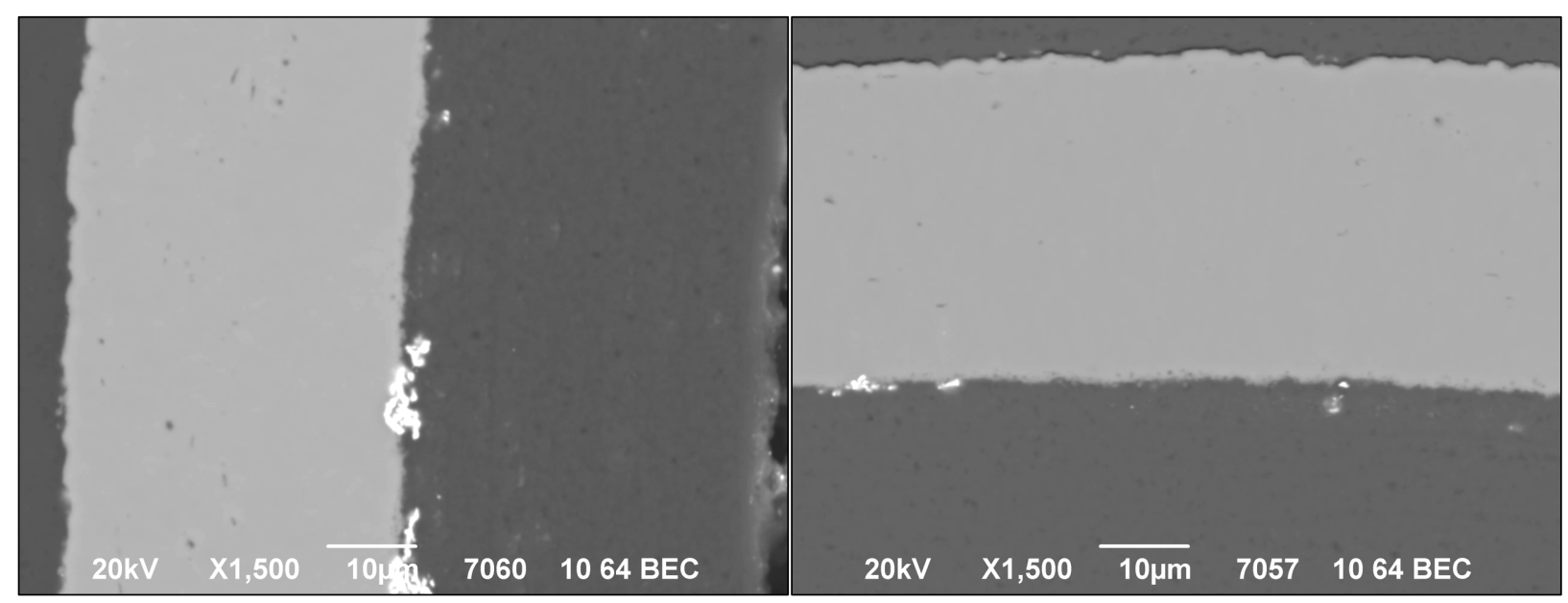

Figure 27. Two 1500x BEC images of Particle 542-RS25 with ${ }^{110 \mathrm{~m}} \mathrm{Ag} \mathrm{M} / \mathrm{C}=1.03$. 


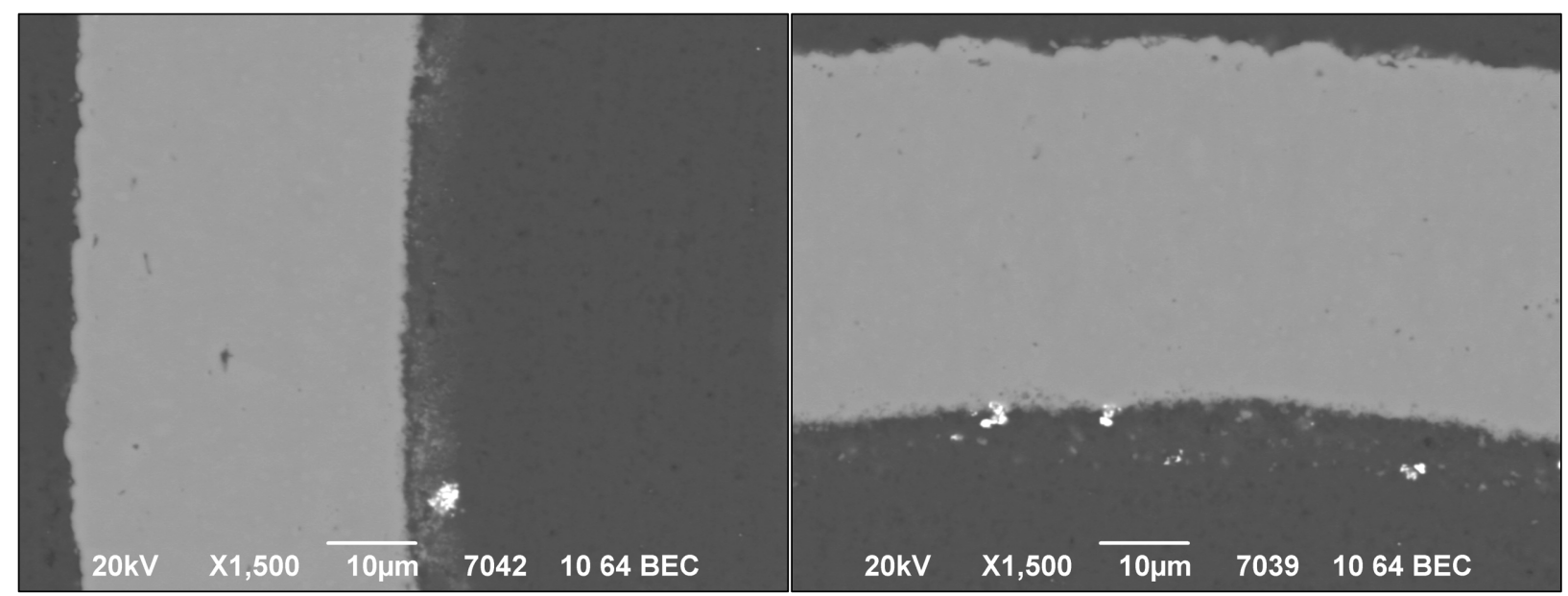

Figure 28. Two 1500x BEC images of Particle 542-RS33 with ${ }^{110 \mathrm{~m}} \mathrm{Ag} \mathrm{M} / \mathrm{C}=1.23$.

The composition of the high-Z features was determined by EDS Point-ID to provide insight on the distribution of fission products in the TRISO layers. Two general categories of observable feature types in the TRISO layers were features with only discernable palladium fission product peaks and features with significant quantities of both palladium and uranium (with a higher concentration of palladium than uranium). These "Pd-only" and "Pd-U" features likely contained palladium and uranium silicides based on prior observations from AGR-1 analysis [van Rooyen et al. 2014] and the higher ratio of silicon in the EDS spectra (using standardless analysis and comparison to $\mathrm{SiC}$ reference spectra).

A variation in feature type and distribution was noted for particles with different silver retention. In general, the lowest-silver particles (542-RS01 and 542-RS07) showed a higher frequency of Pd-U features than other particles. However, the lowest-silver particles still showed a majority of Pd-only features in the $\mathrm{SiC}$ layer with only about $18 \%$ of the analyzed features across the entire thickness of the $\mathrm{SiC}$ layer displaying Pd-U compositions. Figure 29 shows an example of the Pd-only and Pd-U features observed in the SiC layer of Particle 542-RS07 and Figure 30 shows the corresponding EDS spectra.

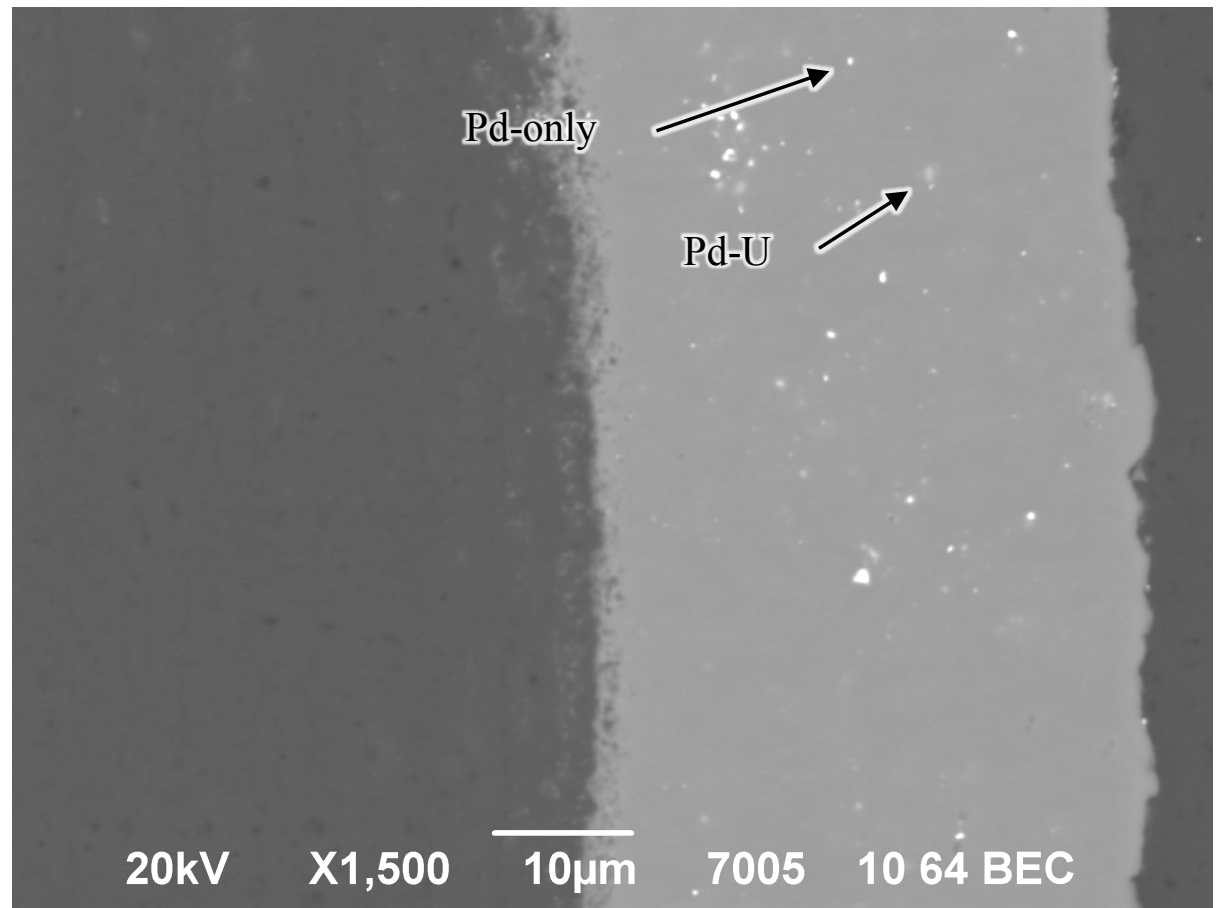

Figure 29. Pd-only and Pd-U features in the SiC layer of lowest-silver Particle 542-RS07 ( $\left.{ }^{110 m} \mathrm{Ag} \mathrm{M} / \mathrm{C}<0.18\right)$. 


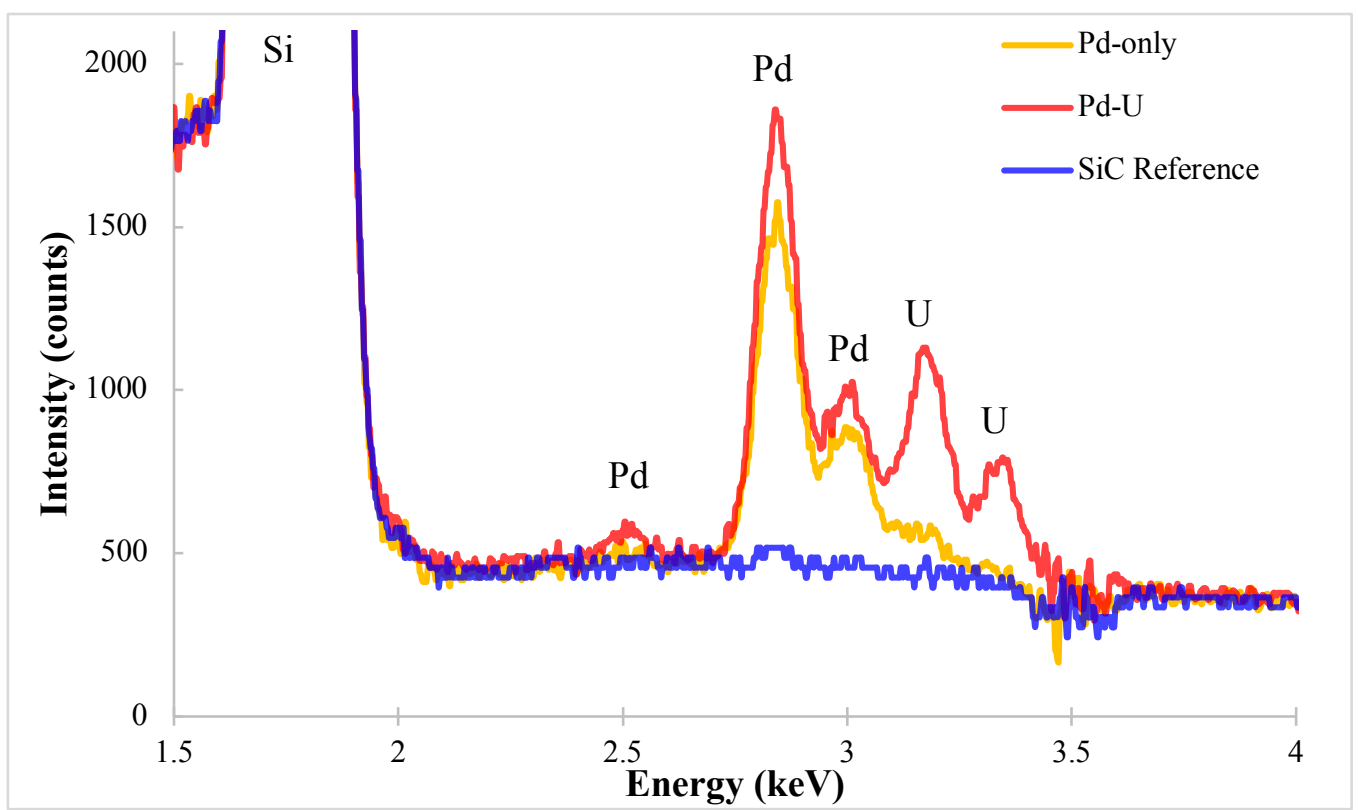

Figure 30 EDS spectra of Point-ID locations centered on Pd-only and Pd-U features shown in Figure 29 for lowest-silver Particle 542-RS07 $\left({ }^{110 \mathrm{~m}} \mathrm{Ag} \mathrm{M} / \mathrm{C}<0.18\right)$.

The features at the IPyC/SiC interface and large micron-sized features, denoted as "large features", protruding into the IPyC layer were found to be predominantly Pd-U features for the lowest-silver particles (542-RS01 and 542-RS07). All analyzed features at the IPyC/SiC interface of Particle 542-RS01 were Pd-U. An example of two Pd-U features at the IPyC/SiC interface of 542-RS01 is shown in Figure 31 , and Figure 32 shows the corresponding EDS spectra.

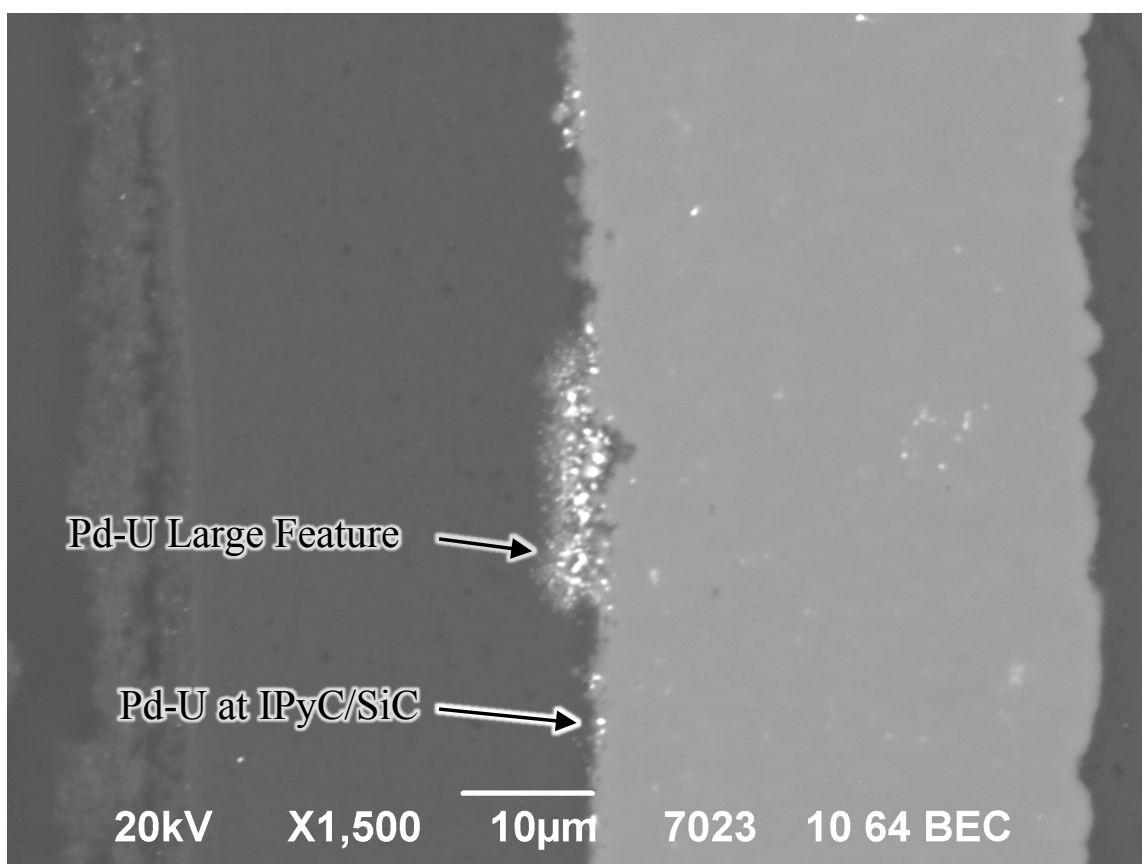

Figure 31. Pd-U features at the IPyC/SiC interface and in a micron-scale pileup features (large feature) in the IPyC layer of lowest-silver Particle 542-RS01 $\left({ }^{110 \mathrm{~m}} \mathrm{Ag} \mathrm{M} / \mathrm{C}<0.18\right)$. 


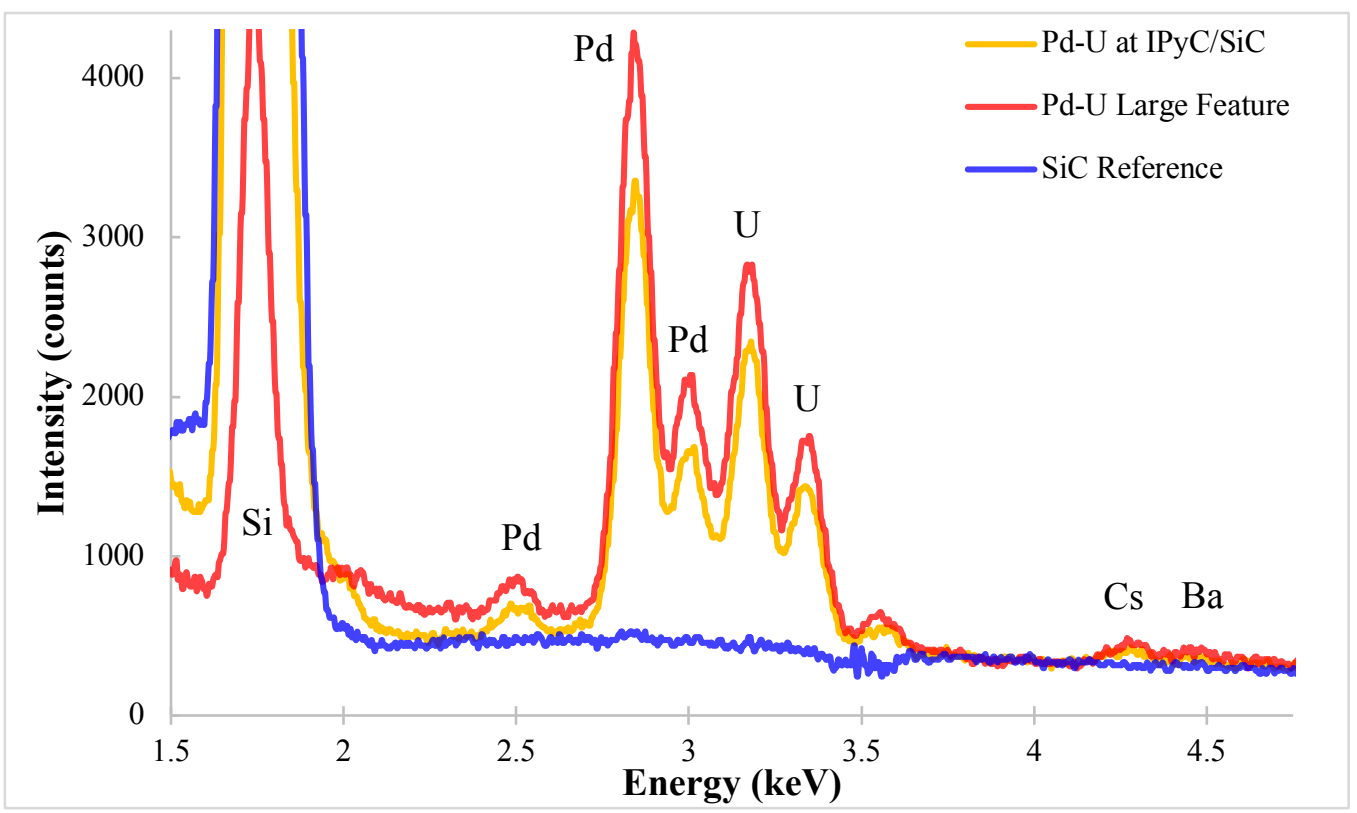

Figure 32. EDS spectra of Point-ID locations centered on Pd-U features shown in Figure 31 for lowest-silver Particle 542-RS01 $\left({ }^{110 \mathrm{~m}} \mathrm{Ag} \mathrm{M} / \mathrm{C}<0.18\right)$.

Features in the IPyC and at the IPyC/SiC interface were found to produce trace signals corresponding to cesium and barium. Other peaks associated with neodymium and cerium were suggested by the Oxford AZtec standardless analysis routine, but the presence of these elements could not be confirmed due to low counts above background. Elevated $\mathrm{Si}-\mathrm{K}_{\alpha 1}$ intensity from the large features away from the $\mathrm{SiC}$ layer suggests that the Pd-U features contained silicides.

Only two analyzed features at the IPyC/SiC interface of lowest-silver Particle 542-RS07 did not conform to the Pd-U feature type. One was a Pd-only feature and the other was a Pd-U-Zr feature, as shown in Figure 33 and Figure 34.

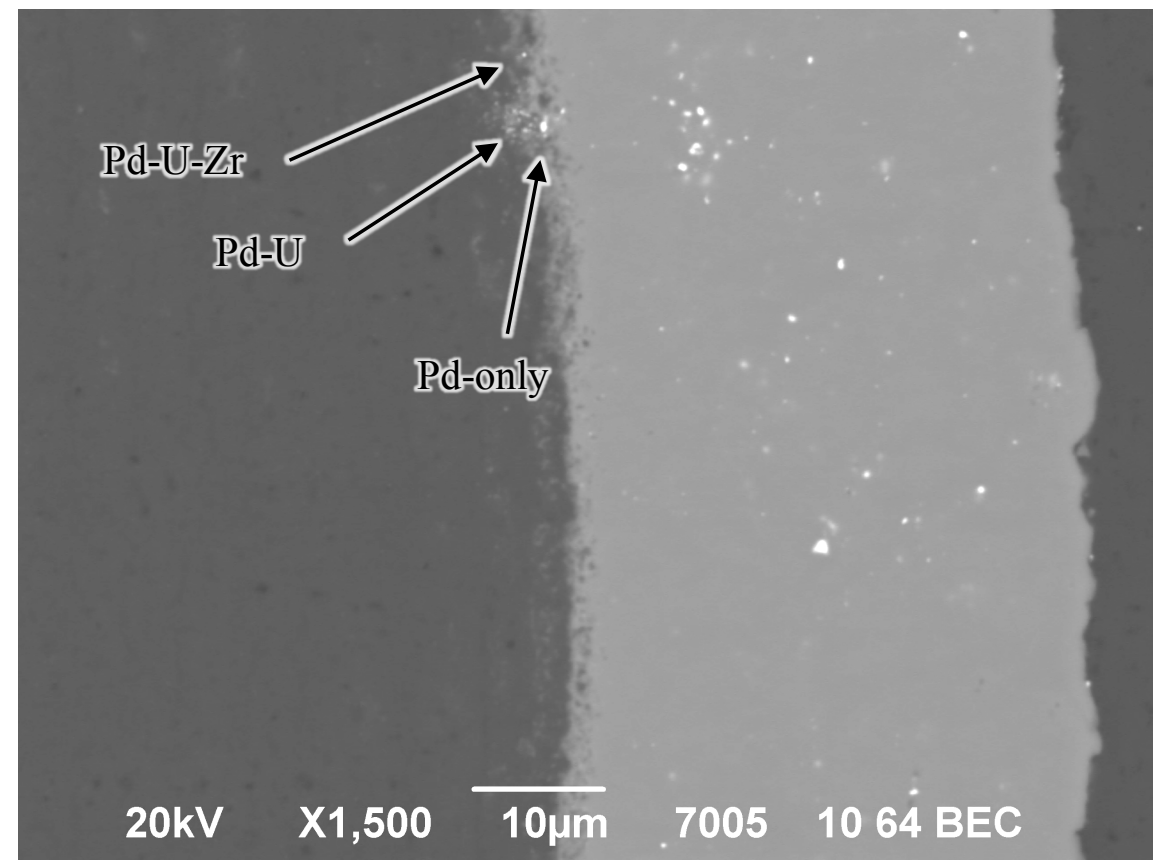

Figure 33. Pd-U, Pd-only, and Pd-U-Zr feature at the IPyC/SiC interface of lowest-silver Particle 542-RS07 $\left({ }^{110 \mathrm{~m}} \mathrm{Ag} \mathrm{M} / \mathrm{C}<0.18\right)$. 


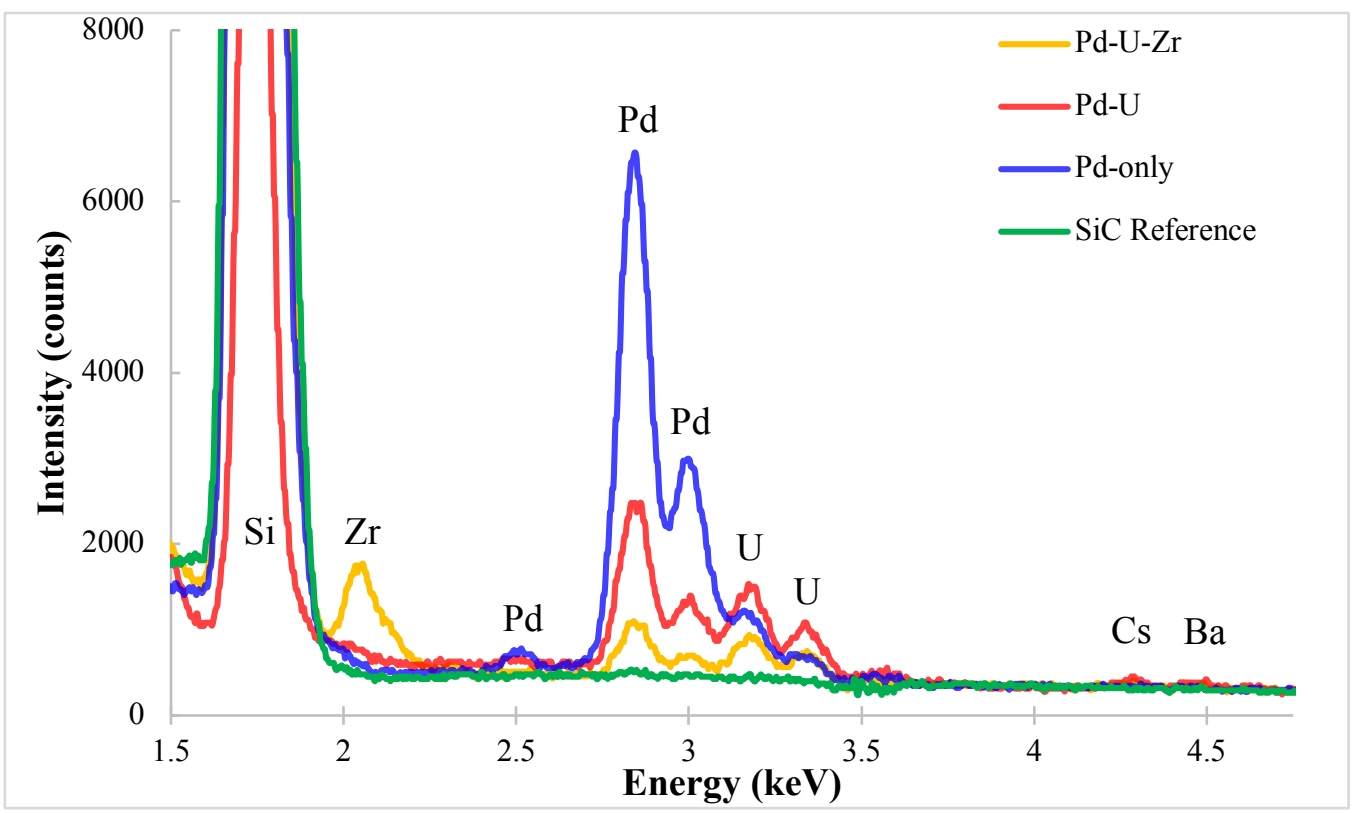

Figure 34. EDS spectra of Point-ID locations centered on Pd-U, Pd-only, and Pd-U-Zr features shown in Figure 33 for lowest-silver Particle 542-RS07 $\left({ }^{110 \mathrm{~m}} \mathrm{Ag} \mathrm{M} / \mathrm{C}<0.18\right)$.

The EDS analysis of the low-silver particles (542-RS11 and 542-RS30) showed only Pd-only features in the $\mathrm{SiC}$ layer. No Pd-U features were observed in the $\mathrm{SiC}$ layer. The features observed at the IPyC/SiC interface and larger, micron-scale features protruding into the IPyC layer were dominated by Pd-only features. Isolated $\mathrm{Pd}-\mathrm{U}$ features were noted along the IPyC/SiC interface and segregated in the large features. A Pd-only feature in the $\mathrm{SiC}$ layer of low-silver Particle 542-RS30 with example spectra typical of all analyzed features in the $\mathrm{SiC}$ of the low-silver particles is shown in Figure 35 and Figure 36. Analyses at locations along the IPyC/SiC interface for low-silver Particle 542-RS11 are shown in Figure 37 and Figure 38. Trace concentrations of cesium and barium were also observed at the IPyC/SiC interface.

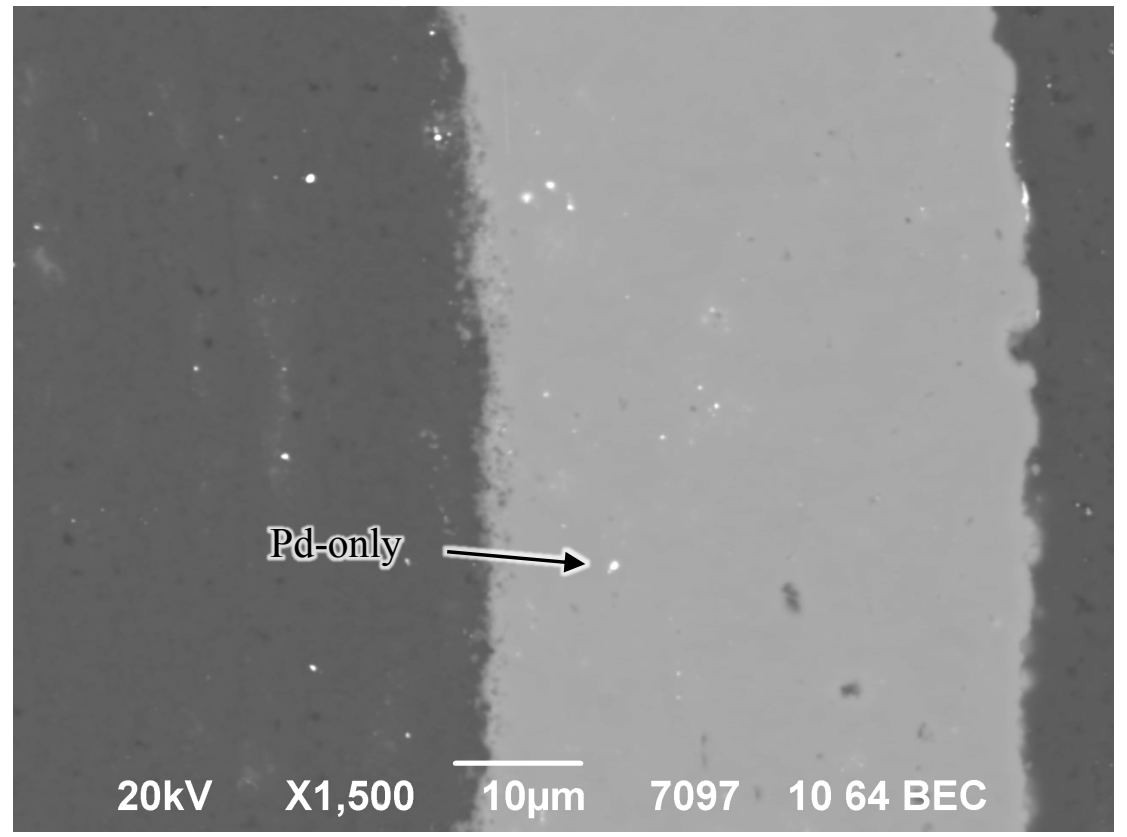

Figure 35. Example of a Pd-only feature in the SiC layer of low-silver Particle 542-RS30 $\left({ }^{110 \mathrm{~m}} \mathrm{Ag} \mathrm{M} / \mathrm{C}=0.32\right)$. 


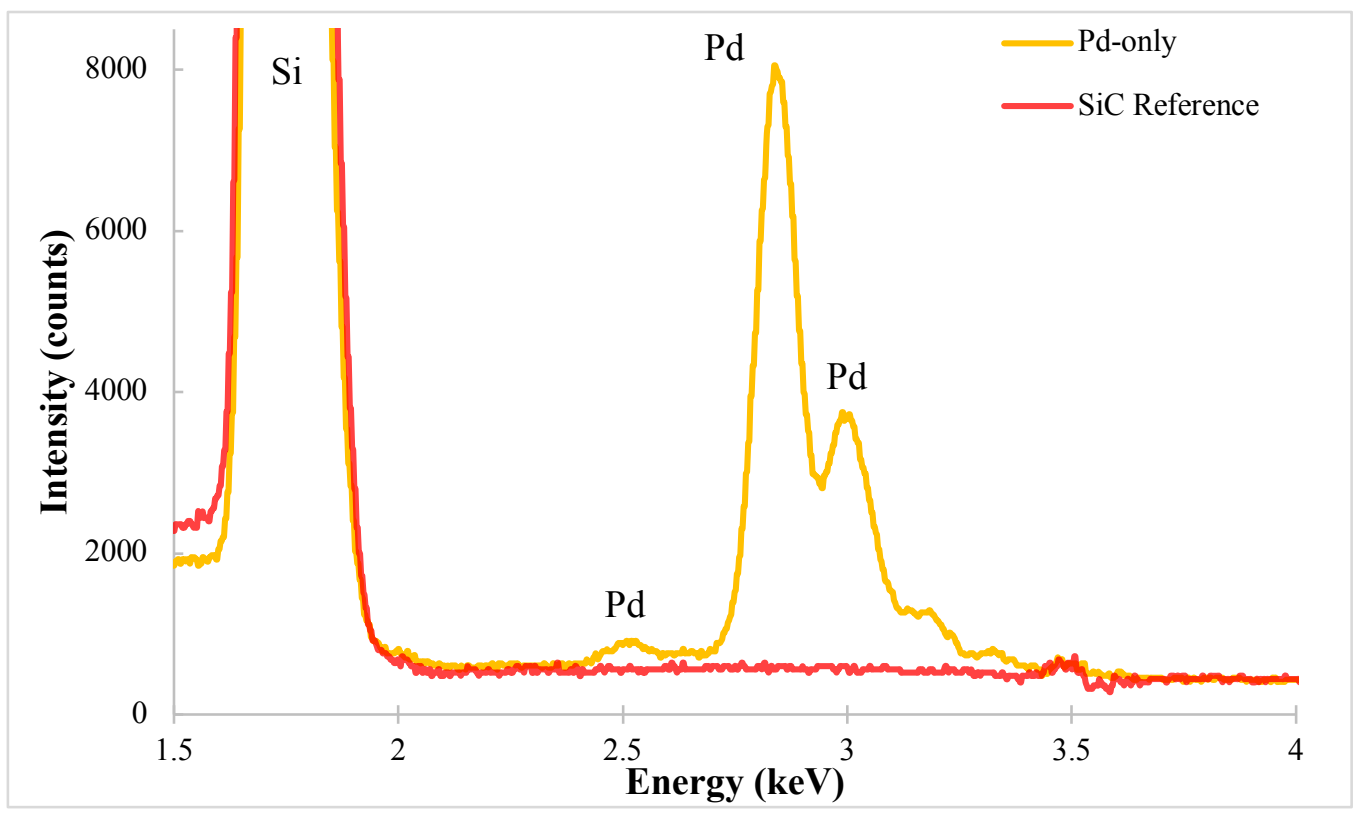

Figure 36. EDS spectra of Point-ID location centered on Pd-only feature shown in Figure 35 for low-silver Particle 542-RS30 $\left({ }^{110 \mathrm{~m}} \mathrm{Ag} \mathrm{M} / \mathrm{C}=0.32\right)$.

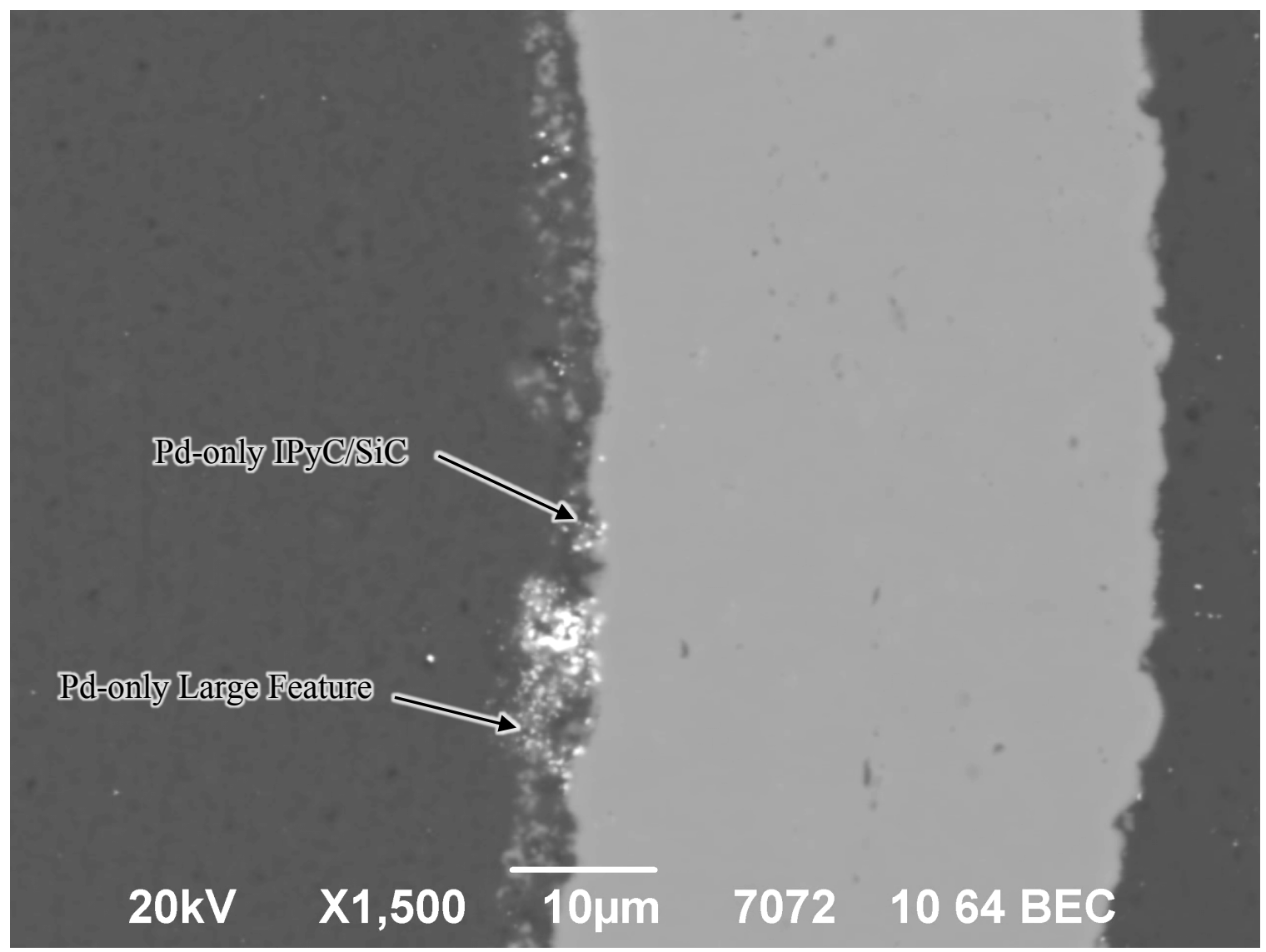

Figure 37. Pd-only feature at the $\mathrm{IPyC} / \mathrm{SiC}$ interface and in a micron-scale pileup feature (large feature) near the IPyC/SiC interface of low-silver Particle 542-RS11 $\left({ }^{110 \mathrm{~m}} \mathrm{Ag} \mathrm{M} / \mathrm{C}=0.23\right)$. 


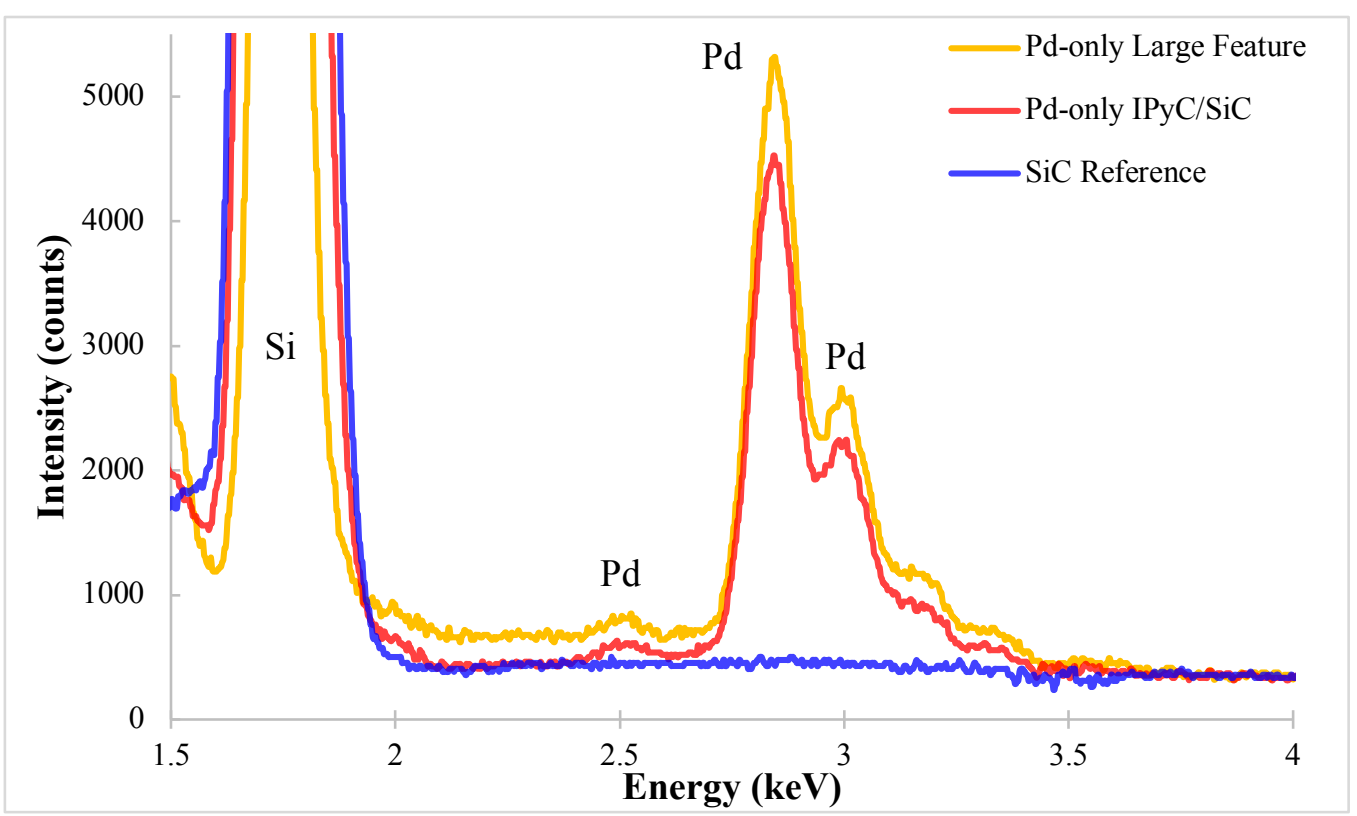

Figure 38. EDS spectra of Point-ID locations centered on Pd-only features shown in Figure 37 for low-silver Particle 542-RS11 $\left({ }^{110 \mathrm{~m}} \mathrm{Ag} \mathrm{M} / \mathrm{C}=0.23\right)$.

The high-silver particles (542-RS25 and 542-RS33) showed no discernable features in the SiC layer and high-intensity features at the IPyC/SiC interface, which were confirmed to be Pd-only features.

Standardless analysis inferred that the features contained silicides. Examples of the Pd-only features near the IPyC/SiC interface of high-silver Particle 542-RS25 are shown in Figure 39 with corresponding EDS spectra in Figure 40.

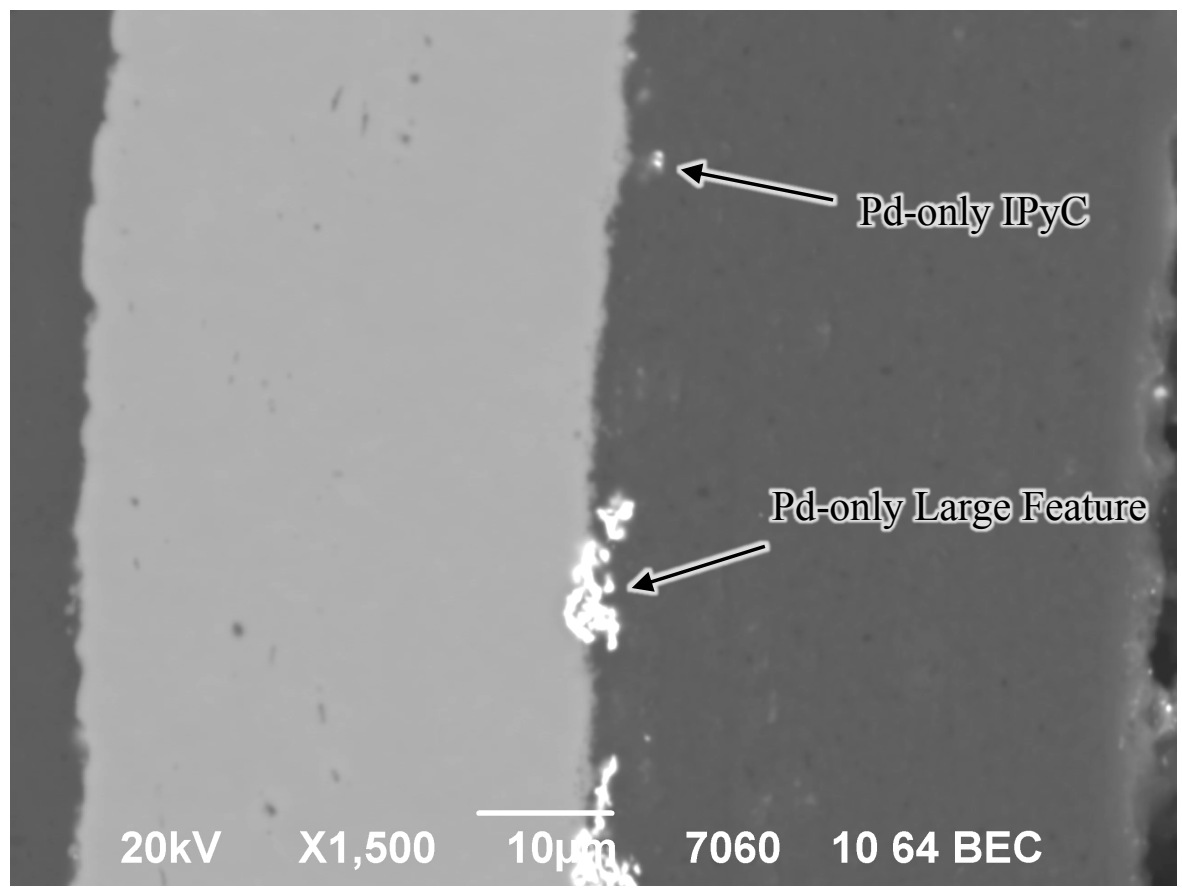

Figure 39. Pd-only features at the IPyC/SiC interface of high-silver Particle 542-RS25 $\left({ }^{110 \mathrm{~m}} \mathrm{Ag} \mathrm{M} / \mathrm{C}=1.03\right)$. 


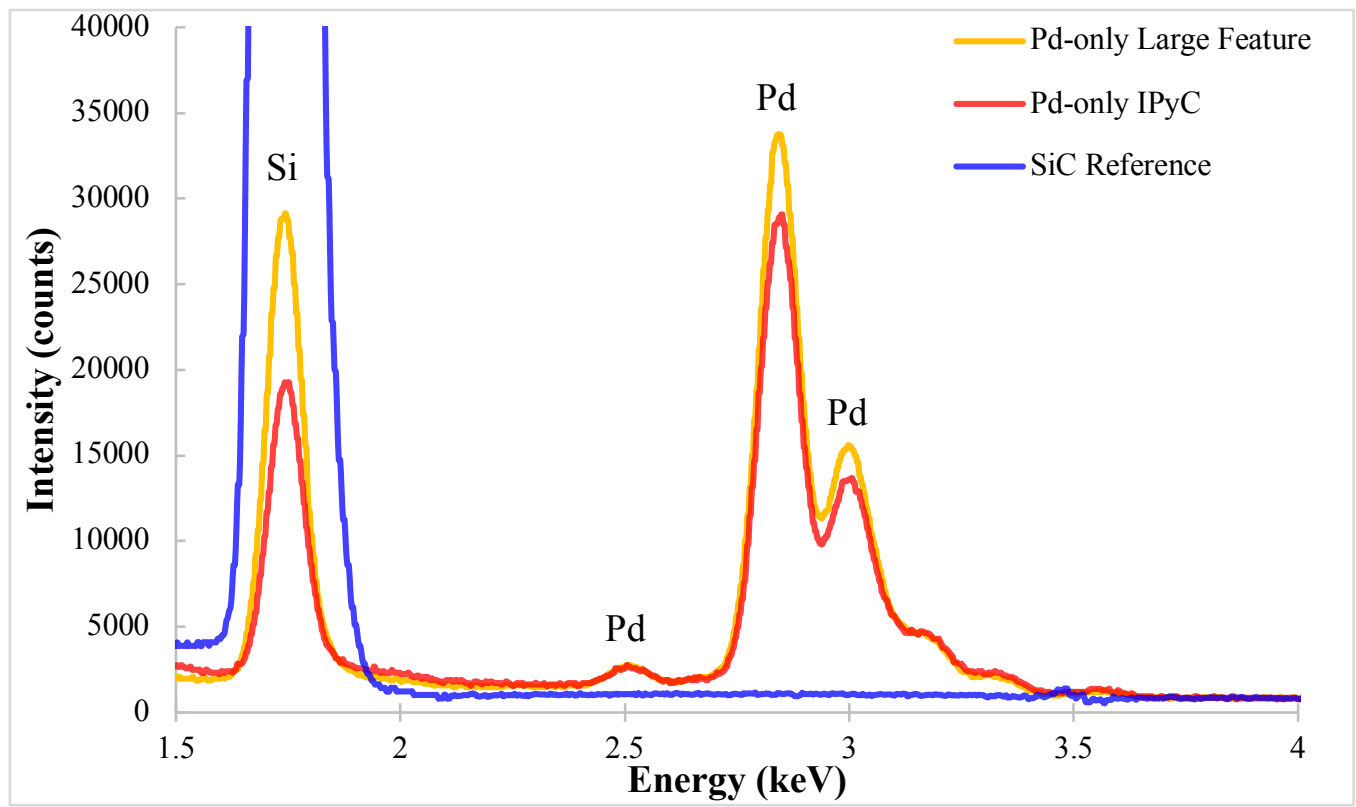

Figure 40. EDS spectra of Point-ID locations centered on Pd-only features shown in Figure 39 for high-silver Particle 542-RS25 $\left({ }^{110 \mathrm{~m}} \mathrm{Ag} \mathrm{M} / \mathrm{C}=1.03\right)$.

There was an unusual large high-contrast feature present at the SiC/OPyC interface in Particle 542-RS01. Point-ID analysis showed the composition was predominantly iron and chromium (Figure 41 and Figure 42). It is probable that this was debris deposited during grinding of the cross section. Figure 9 provides further evidence that this was debris, in the form of an associated gouge in the OPyC and chip in the $\mathrm{SiC}$.

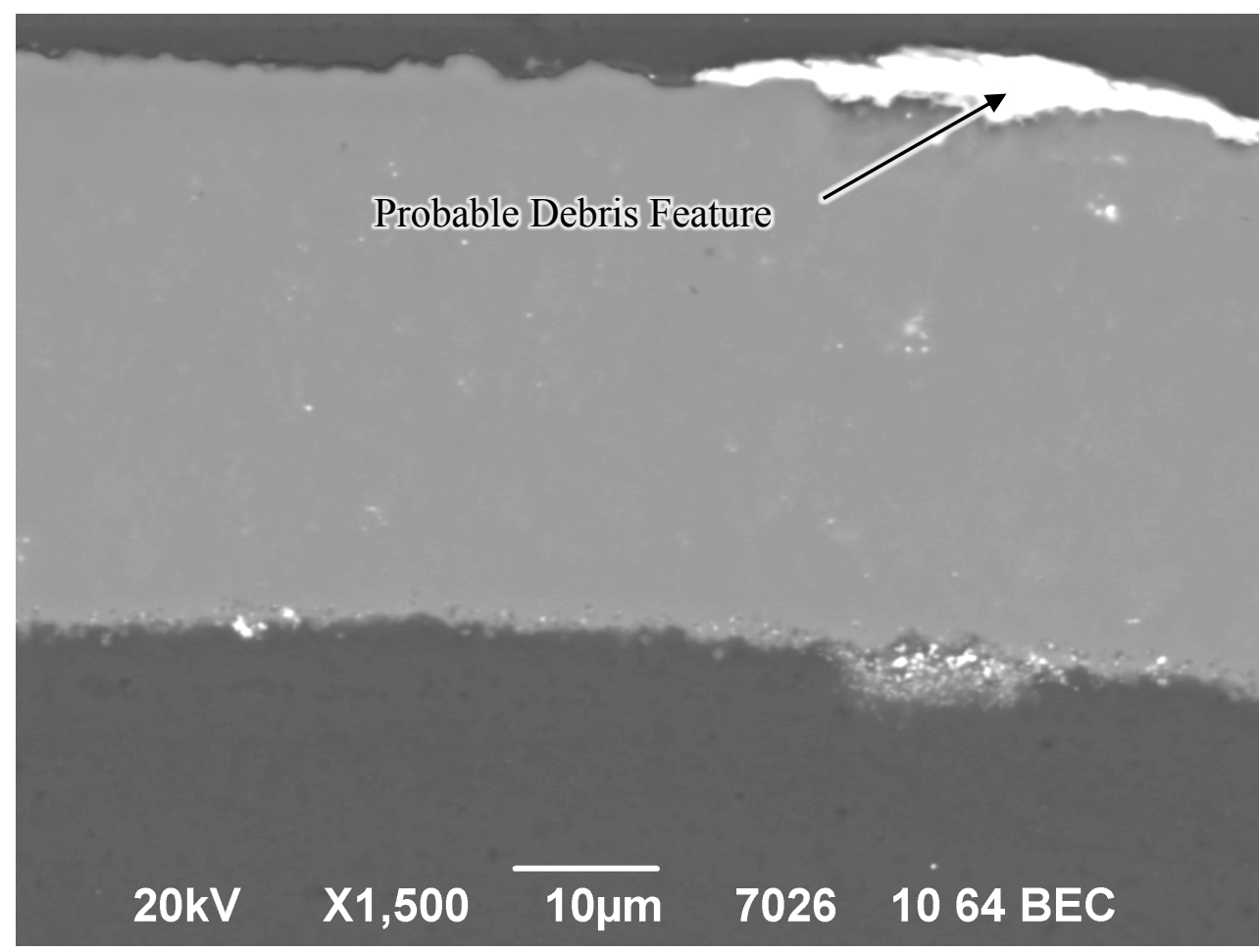

Figure 41. Probable debris at the SiC/OPyC interface in lowest-silver Particle 542-RS01 $\left({ }^{110 \mathrm{~m}} \mathrm{Ag} \mathrm{M} / \mathrm{C}<0.18\right)$. 


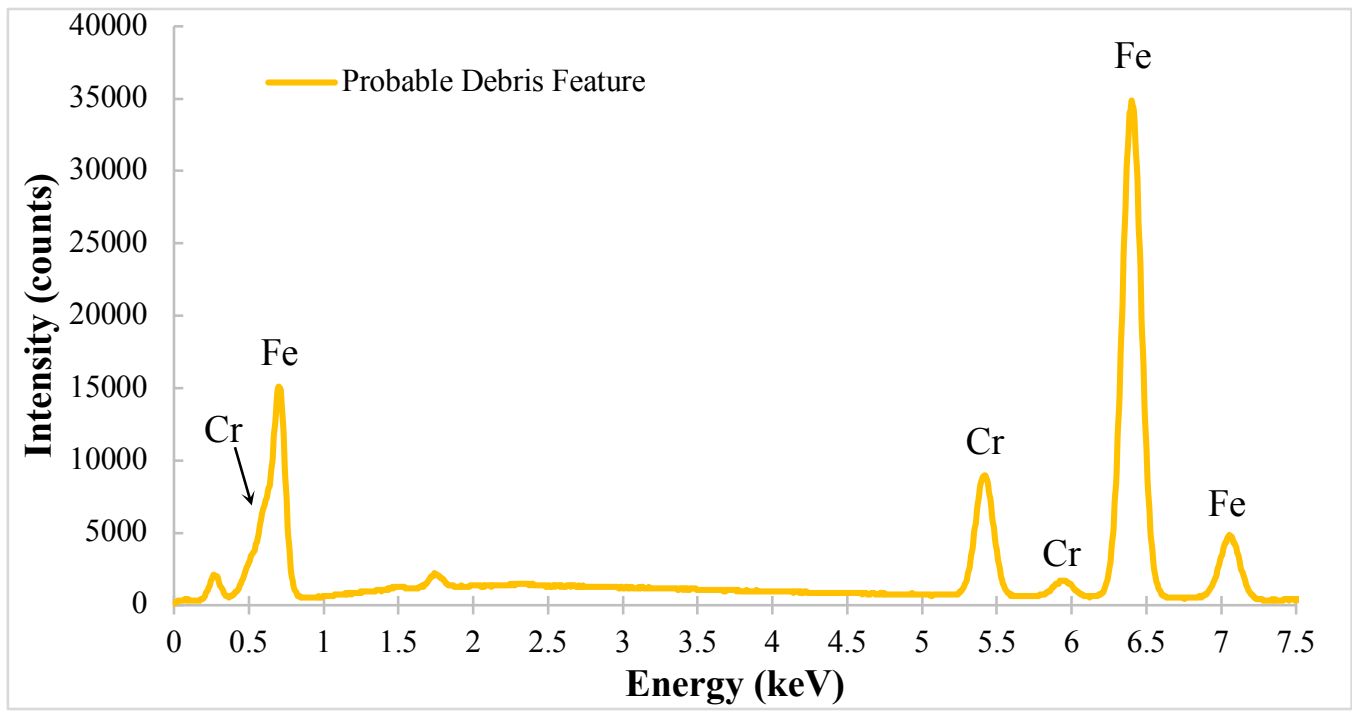

Figure 42. EDS spectra of Point-ID location centered on probable debris shown in Figure 41 for lowest-silver Particle 542-RS01 $\left({ }^{110 \mathrm{~m}} \mathrm{Ag} \mathrm{M} / \mathrm{C}<0.18\right)$.

The optical micrographs in Section 4.1 (e.g., Figure 9) show a buffer/kernel interface region that appeared to have higher-density than the rest of the buffer. A series of Point-ID analyses were performed across this region in Particle 542-RS01. Multiple fission products were observed, as would be expected from fission recoil and surface reaction. The region was mostly carbon, indicating it was part of the original buffer layer, and the second most prevalent element was uranium, indicating a uranium diffusion/reaction zone. The relative atomic\% $\mathrm{U}$ decreased as a function of distance from the kernel. Relative concentration at the points marked in Figure 43 based on spectra shown in Figure 44 were: 17.6\% (Kernel Reference), $3.4 \%$ (Kernel Adjacent), $1.5 \%$ (U-Rich Zone), $0.2 \%$ (Dense Buffer), and insignificant signal or $\sim 0.0 \%$ (Buffer Reference).

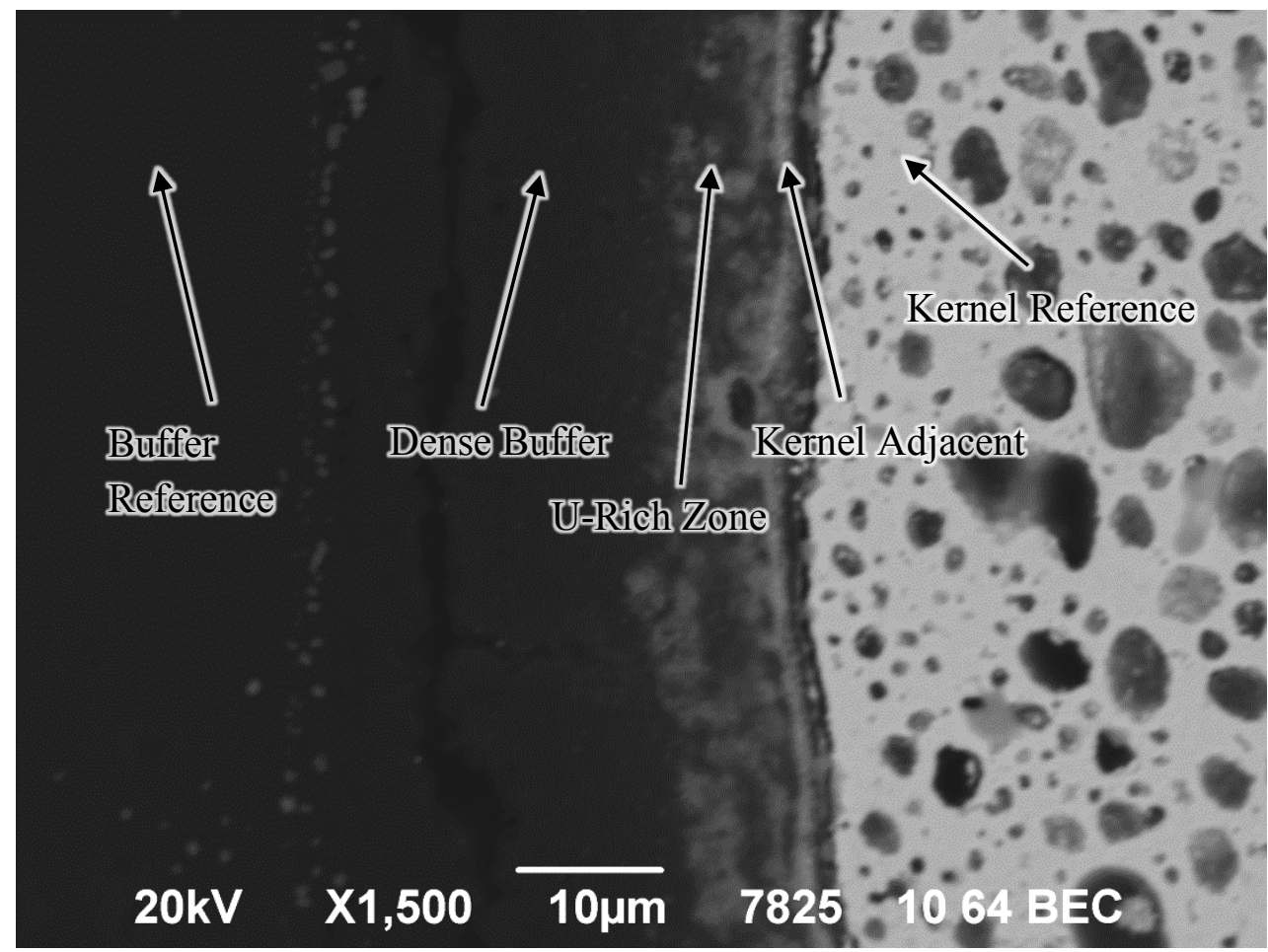

Figure 43. Point-ID analysis locations near buffer/kernel interface in Particle 542-RS01. 


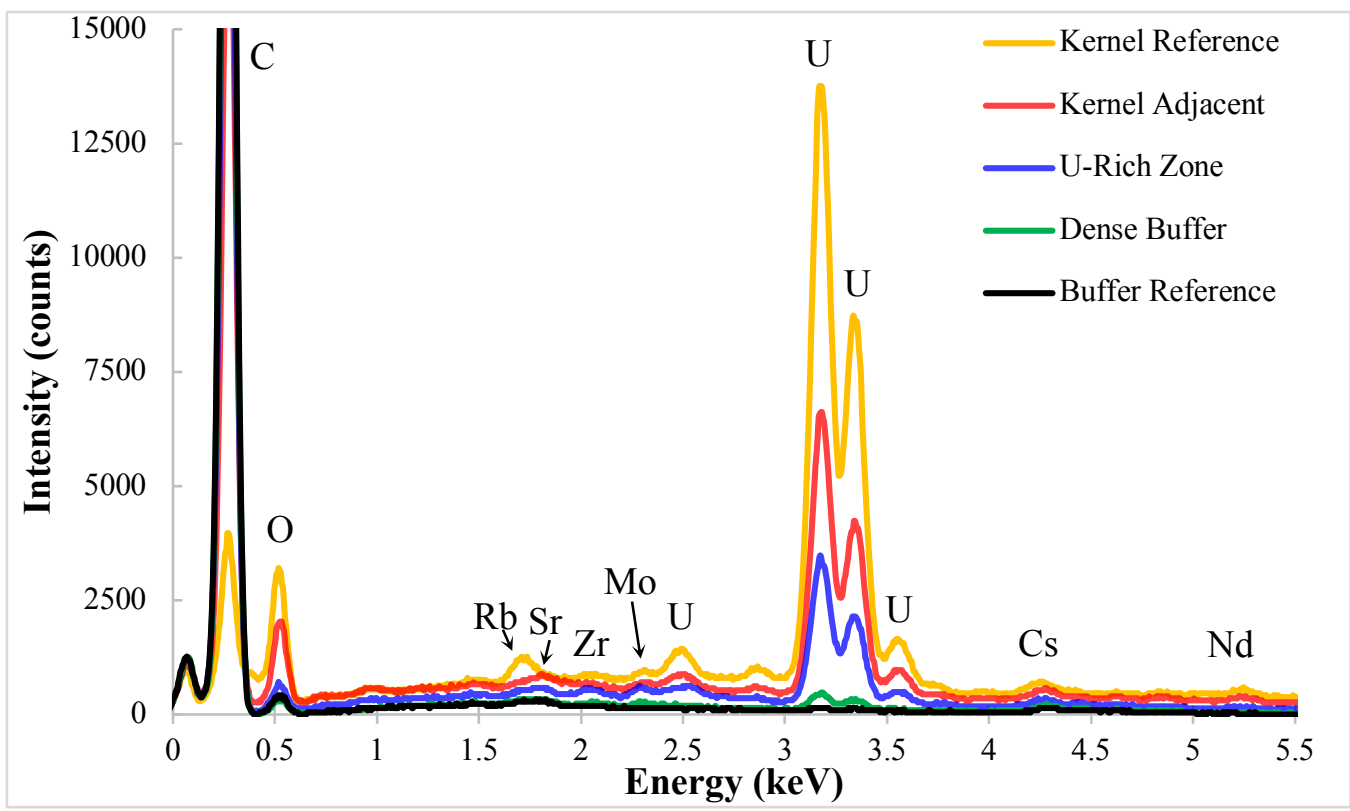

Figure 44. EDS spectra of Point-ID locations marked in Figure 43 of Particle 542-RS01.

Figure 9 shows several buffer-colored spots in the kernel. Point-ID analysis (Figure 45 and Figure 46) showed these spots were predominantly carbon, with uranium concentrations similar to the buffer region adjacent to the kernel. The buffer/kernel interface region in this part of the particle also showed the relative atomic $\% \mathrm{U}$ decreased as a function of distance from the kernel.

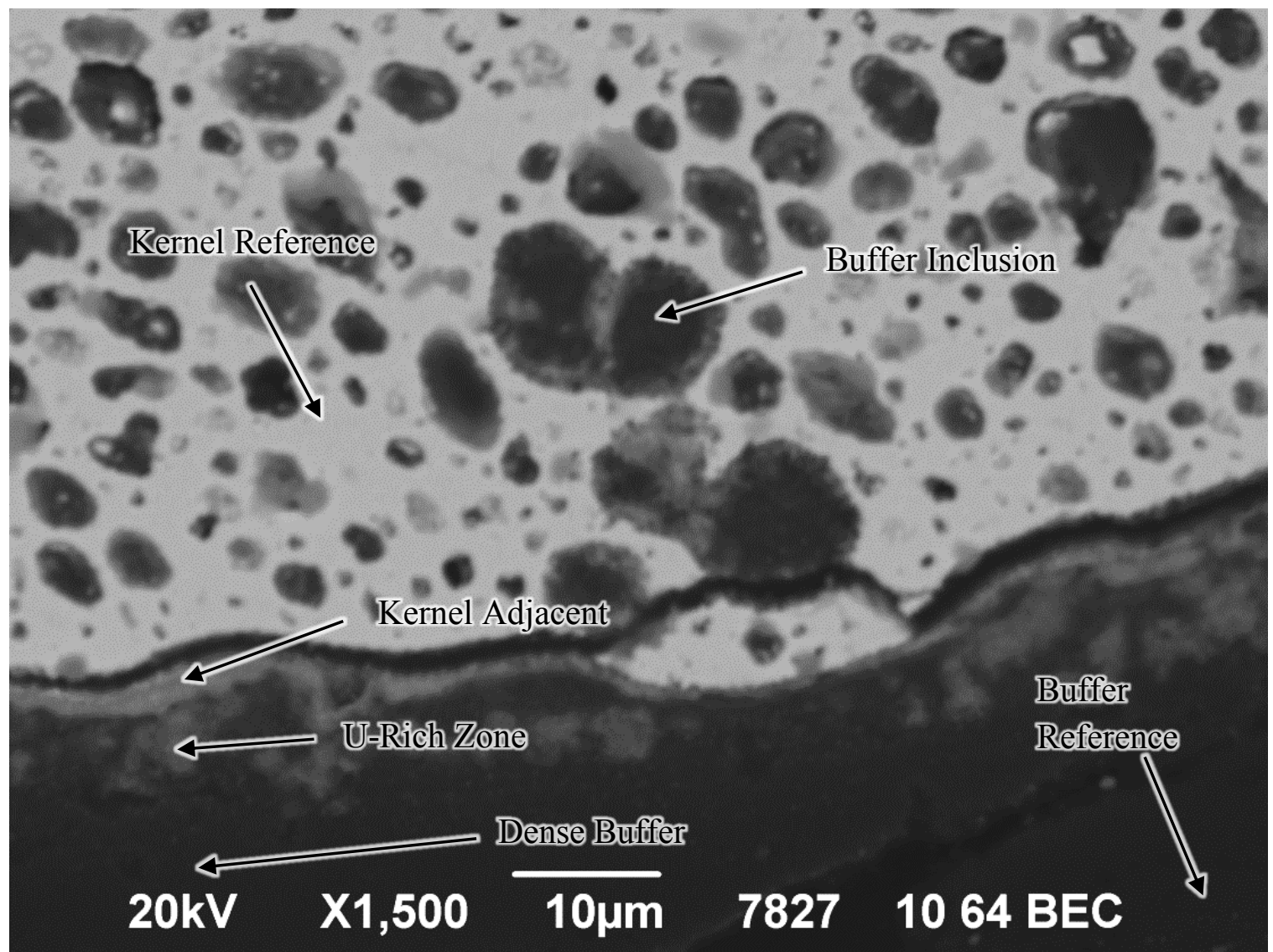

Figure 45. Point-ID analysis locations in Particle 542-RS01 surrounding area that showed buffer-colored material inside the kernel (Figure 9). 


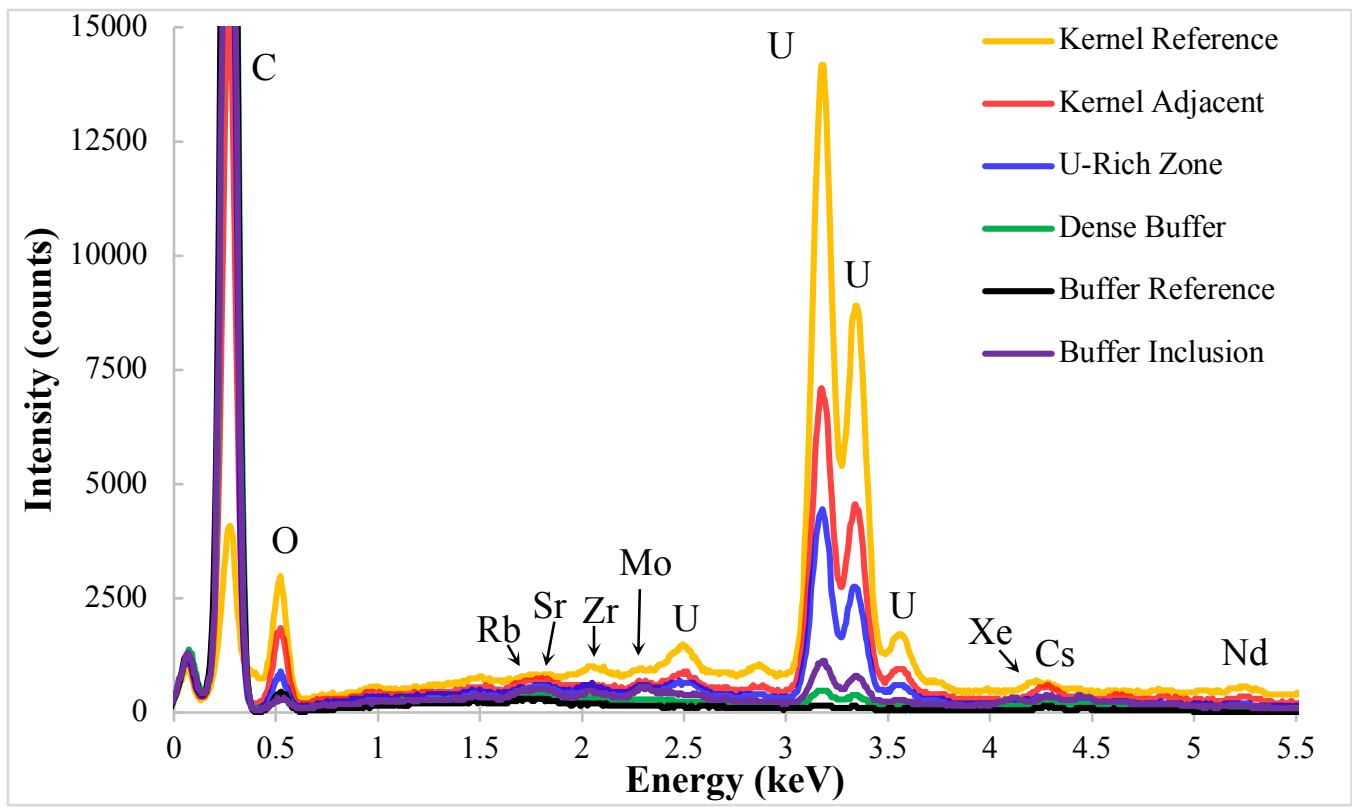

Figure 46. EDS spectra of Point-ID locations marked in Figure 45 of Particle 542-RS01. 


\section{X-RAY TOMOGRAPHY}

As described in Section 4, the four-hour IMGA measurement data in Table 5 were used to select particles for microstructural analyses from various regions of the ${ }^{110 \mathrm{~m}} \mathrm{Ag}$ distribution (Figure 5), while other isotope inventories in these particles were generally close to average. Table 8 lists the particles selected for x-ray tomography using the same calculation method as was used for Table 7.

Table 8. Particles selected for x-ray tomography

\begin{tabular}{|c|c|c|c|c|c|c|c|}
\hline \multicolumn{8}{|c|}{ Measured versus calculated inventory ${ }^{a}$} \\
\hline Particle & ${ }^{106} \mathbf{R u}$ & ${ }^{110 \mathrm{~m}} \mathrm{Ag}^{c}$ & ${ }^{125} \mathrm{Sb}$ & ${ }^{134} \mathrm{Cs}$ & ${ }^{137} \mathrm{Cs}$ & ${ }^{144} \mathrm{Ce}$ & ${ }^{154} \mathbf{E u}$ \\
\hline 542-RS05 & 1.18 & $<0.18$ & 0.75 & 0.98 & 1.00 & 1.12 & 0.84 \\
\hline 542-RS32 & 1.17 & 0.91 & 0.77 & 0.97 & 0.98 & 1.14 & 0.85 \\
\hline 542-RS13 & 1.15 & 1.01 & 0.75 & 0.99 & 0.99 & 1.13 & 0.86 \\
\hline
\end{tabular}

\begin{tabular}{|c|c|c|c|c|c|c|c|}
\hline \multicolumn{8}{|c|}{ Measured versus average inventory ${ }^{b}$} \\
\hline Particle & ${ }^{106} \mathrm{Ru}$ & ${ }^{110 \mathrm{~m}} \mathrm{Ag}^{c}$ & ${ }^{125} \mathrm{Sb}$ & ${ }^{134} \mathrm{Cs}$ & ${ }^{137} \mathrm{Cs}$ & ${ }^{144} \mathrm{Ce}$ & ${ }^{154} \mathbf{E u}$ \\
\hline 542-RS05 & 1.04 & $<0.24$ & 1.01 & 0.98 & 0.96 & 1.04 & 0.98 \\
\hline 542-RS32 & 1.03 & 1.21 & 1.04 & 0.98 & 0.95 & 1.06 & 0.98 \\
\hline 542-RS13 & 1.01 & 1.34 & 1.01 & 1.00 & 0.96 & 1.05 & 1.00 \\
\hline
\end{tabular}

${ }^{a} \mathrm{M} / \mathrm{C}$ values were adjusted for fissile material and burnup using the normalized ${ }^{137} \mathrm{Cs}$ activity, except for ${ }^{137} \mathrm{Cs}$, which used the normalized ${ }^{144} \mathrm{Ce}$ activity.

${ }^{b}$ Measured versus average activity inventory values were adjusted for fissile material and burnup using the normalized ${ }^{137} \mathrm{Cs}$ activity, except for ${ }^{137} \mathrm{Cs}$, which used the normalized ${ }^{144} \mathrm{Ce}$ activity.

${ }^{c}$ Less than values indicate the ${ }^{110 \mathrm{~m}} \mathrm{Ag}$ activity was below the detection limit.

Figure 47-Figure 49 show orthogonal pairs of x-ray tomograms acquired as described in [Hunn et al. 2013a]. All three imaged particles had fractured buffer. Bright spots at the IPyC/SiC interface indicate the presence of fission products with higher atomic number than the carbon and silicon in the layers. Particles 542-RS32 (Figure 48) and 542-RS13 (Figure 49) both showed evidence of IPyC fracture. The IPyC fracture in Particle 542-RS13 (Figure 49) appeared to be a partial tear that did not go all the way through the IPyC (based on examination of the full three-dimensional tomographic data set). The buffer/IPyC interface on one side of this tear was intact, while the buffer was torn away from the IPyC on the other side of the tear. This type of structure has been observed in other AGR particles with fractured IPyC and indicates that the IPyC tear was caused by the buffer pulling away from the interface as it shrank under irradiation. The IPyC crack in Particle 542-RS32 appeared to traverse the entire layer and was aligned with a radial crack in the buffer. This is another IPyC fracture structure that has been observed in AGR fuel particles [Hunn et al. 2014d], especially when the buffer/IPyC interface is still intact. However, whereas this IPyC fracture may have occurred in Particle 542-RS32 while the interface was intact, it was no longer intact at the time the image was obtained. 

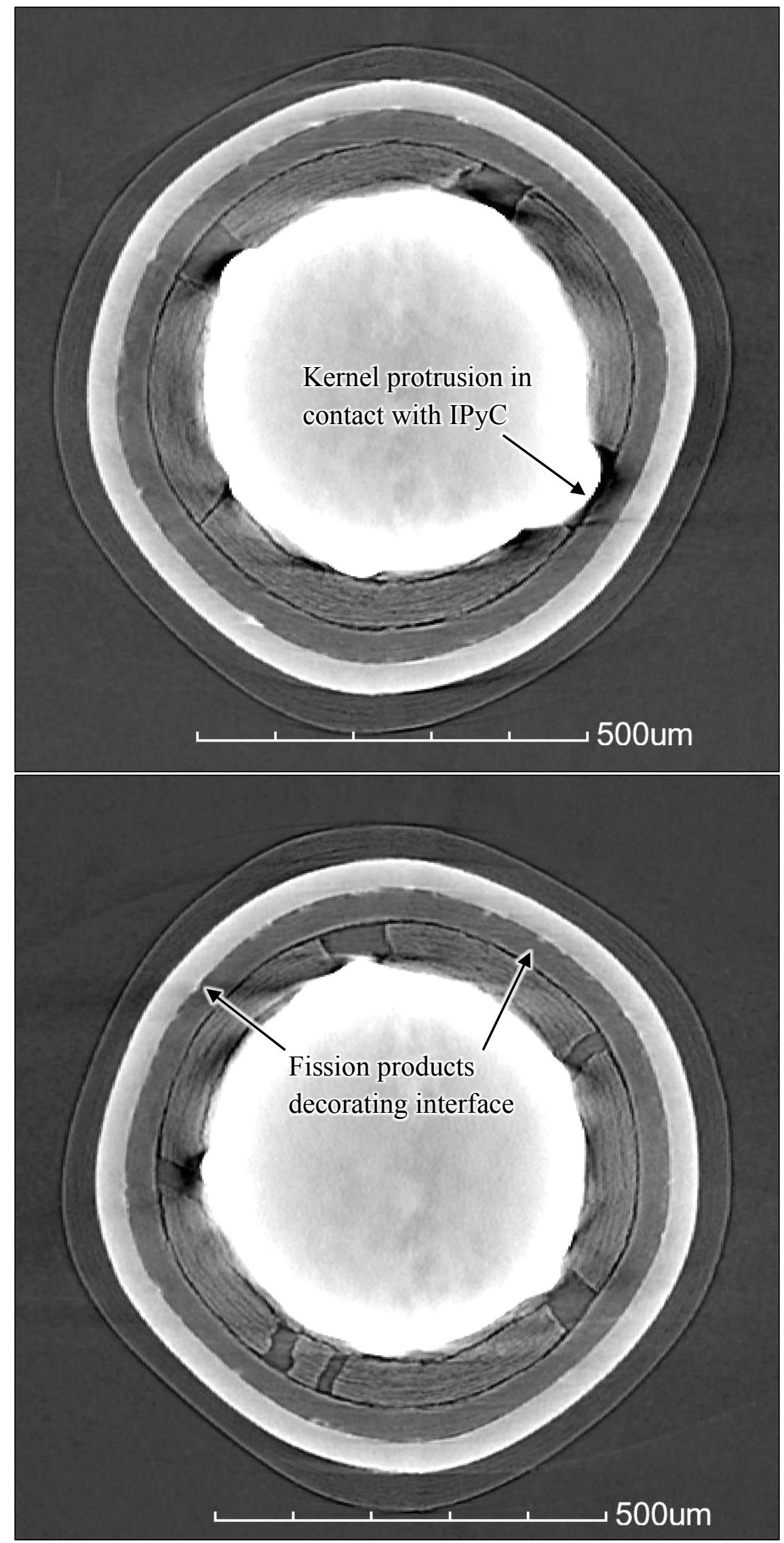

Figure 47. Orthogonal oblique tomograms through center of Particle 542-RS05. 

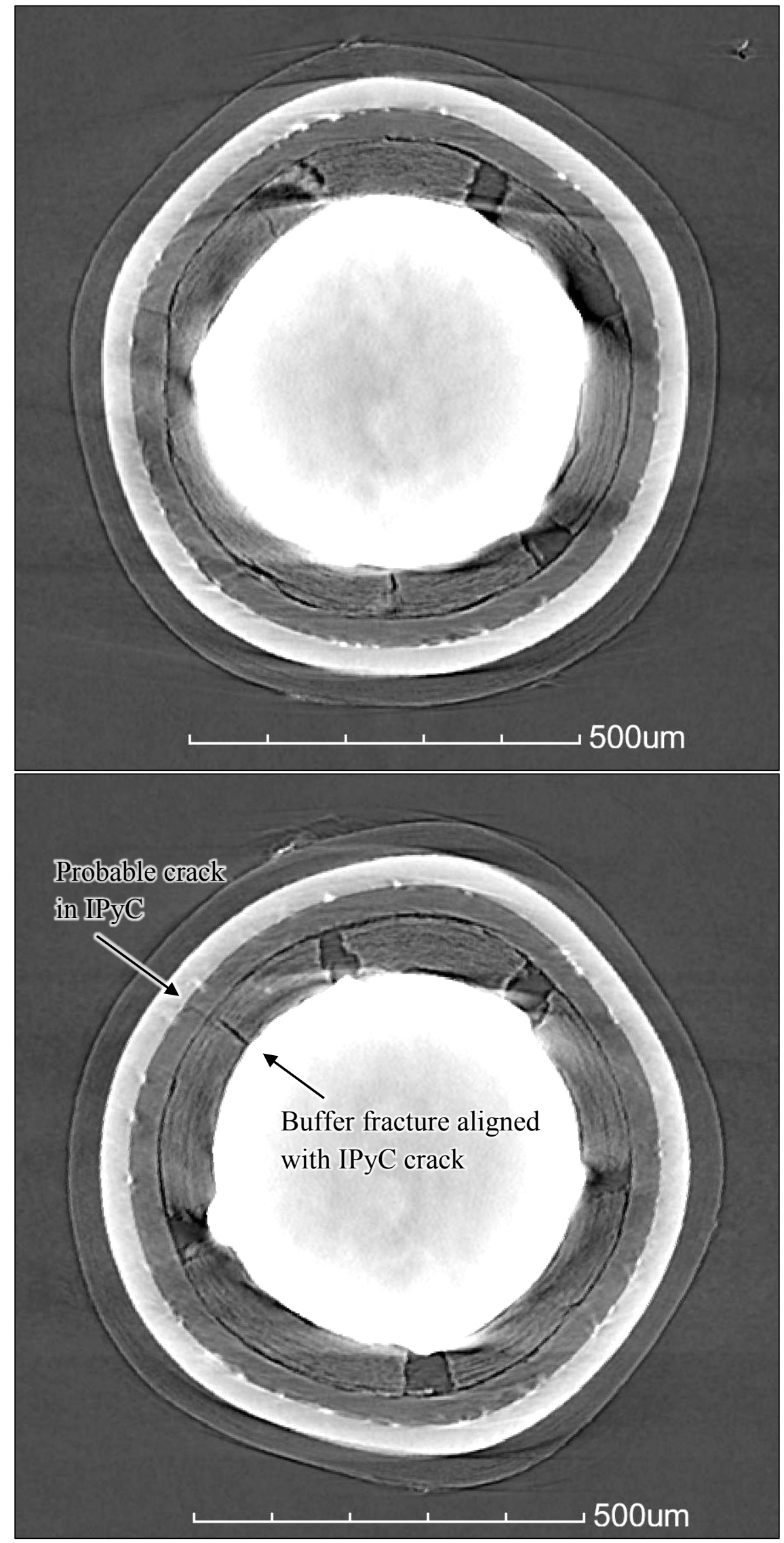

Figure 48. Orthogonal oblique tomograms through center of Particle 542-RS32. 

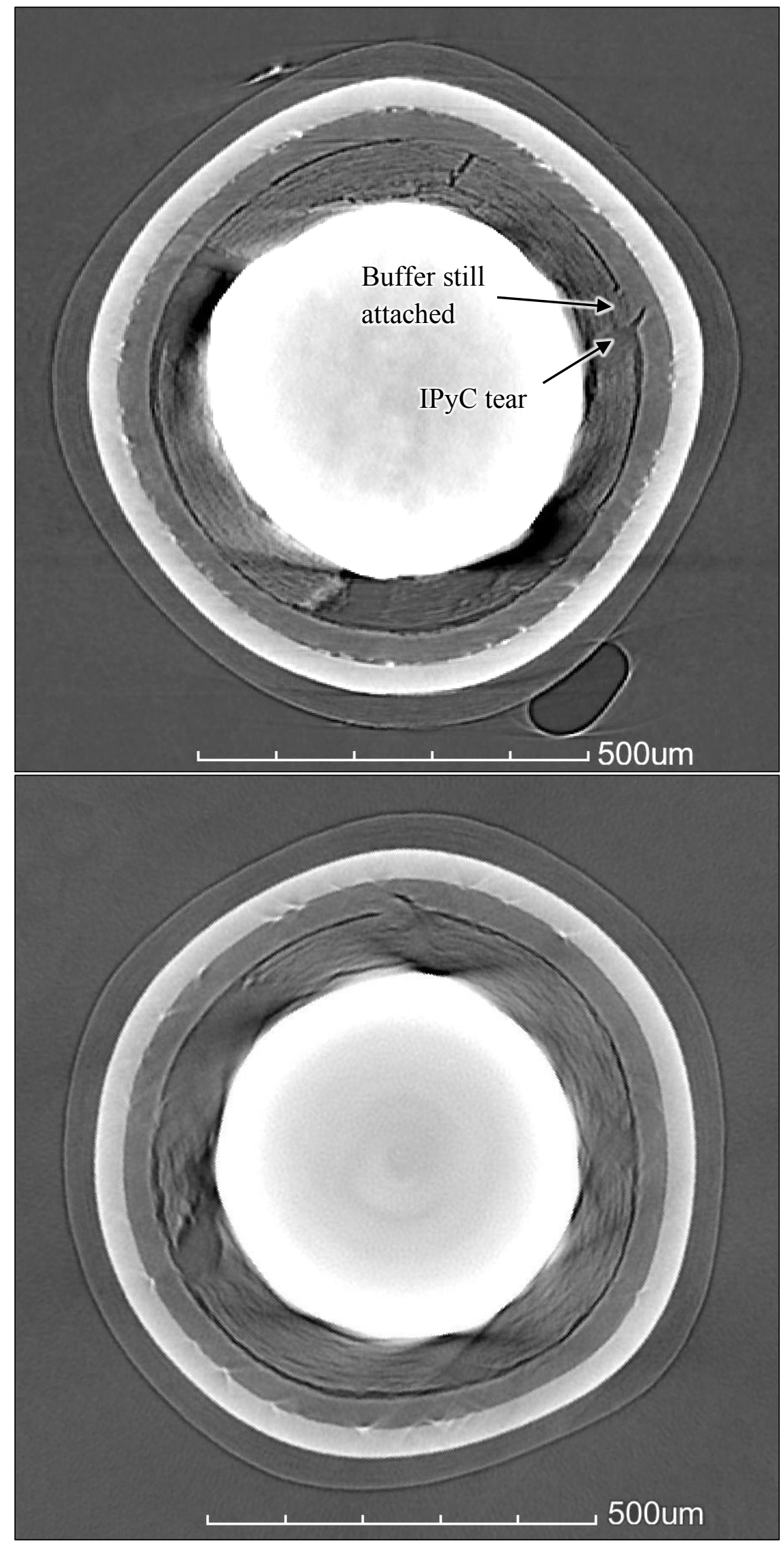

Figure 49. Orthogonal oblique tomograms through center of Particle 542-RS13. 


\section{CONCLUSION}

Destructive PIE was completed on as-irradiated AGR-2 UCO Compact 5-4-2 as part of a comprehensive AGR-2 PIE effort. The compact was deconsolidated, and leach-burn-leach analysis performed to measure exposed fission products. Pre-burn leach results were very low for uranium, plutonium, and most other measured isotopes. This indicates that no particles had exposed kernels as a result of complete failure or damage of the holistic TRISO coating. As is typical for AGR UCO-TRISO fuel, silver and europium were the most prevalent fission products in the as-irradiated compact that were not retained within the $\mathrm{SiC}$ layers in the pre-burn leach phase. Mass spectrometry analysis for stable isotopes showed that palladium was released similar to silver and samarium and gadolinium were released similar to europium. Uranium and plutonium detected in the first post-burn particle leach solution indicated that a kernel had been exposed either because of particle handling or due to a failed-SiC layer. The amounts of other isotopes detected in the post-burn particle leaching were dominated by the exposed kernel.

The TRISO particles in Compact 5-4-2 were separated from the deconsolidated matrix debris so that the TRISO particles could be surveyed with IMGA. No particles with abnormally low cesium or cerium were detected, as would be expected if there were a particle with failed SiC. Four-hour counting of the gamma spectrum emitted from 44 randomly-selected particles showed a broad spread in the silver retention in individual particles, with some particles retaining essentially all their silver and some retaining very little.

Microstructural analyses using x-ray tomography and materialographic methods were performed to investigate radiation-induced changes in the particles and identify trends related to the variable silver release. Optical microscopy was effective at characterizing the general behavior of the buffer and kernel. Buffer fracture was prevalent with $22 / 29=76 \%$ of the particles shown in Figure 15 exhibiting buffer fracture and $30 / 38=79 \%$ of all particles analyzed by x-ray tomography and cross sectioning revealing fractured buffer. Buffer fracture was accompanied by enhanced volumetric swelling of the kernel, which led to asymmetric protrusion of the kernel into the gap between buffer fragments and larger pore formation. There was no evidence that the observed buffer fracture or kernel swelling led to reduced fission product retention. IPyC fracture was evident in two of the three particles imaged with $\mathrm{x}$-ray tomography, and this type of IPyC fracture has been observed to lead to enhanced $\mathrm{SiC}$ failure during irradiation or safety testing [Hunn 2014d]. In contrast, IPyC fracture was not evident in the crosssectioned particles, which points to the inadequacy of the two-dimensional materialographic analysis for identifying localized features such as IPyC cracks.

Backscattered-electron imaging and EDS analysis showed definite trends in the distribution of fission products within the $\mathrm{SiC}$ layer for varied degrees of silver release. Particles that experience the most silver release displayed isolated palladium or palladium plus uranium features throughout the $\mathrm{SiC}$. The Pd-U features were not observed in particles that had measurable but lower silver release, and the size and number density of the Pd-only features were lower. Particles that retained most of their silver did not show any discernable palladium or uranium features in the $\mathrm{SiC}$. The prevalence of uranium at the $\mathrm{IPyC} / \mathrm{SiC}$ interface also tracked with the amount of silver release. While the palladium and uranium in and near the $\mathrm{SiC}$ may or may not have been directly involved with the silver release, the trends do at least indicate that particles with high silver release are experiencing conditions that enhance the transport of palladium and uranium to and through the $\mathrm{SiC}$. The most obvious of these would be an increase in temperature. 


\section{REFERENCES}

Barnes, C.M. and D.W. Marshall. 2009. FY 2009 Particle Fabrication and Coater Test Report. INL/EXT-09-16545, Revision 0. Idaho Falls, Idaho: Idaho National Laboratory.

Collin, B.P. 2014. AGR-2 Irradiation Test Final As-Run Report. INL/EXT-14-32277, Revision 2. Idaho Falls, Idaho: Idaho National Laboratory.

Demkowicz, P.A. 2013. AGR-2 Post Irradiation Examination Plan. PLN-4616, Revision 0. Idaho Falls, Idaho: Idaho National Laboratory.

Demkowicz, P.A., J.D. Hunn, R.N. Morris, I.J. van Rooyen, T.J. Gerczak, J.M. Harp, and S.A. Ploger 2015. AGR-1 Post Irradiation Examination Final Report. INL/EXT-15-36407, Revision 0. Idaho Falls, Idaho: Idaho National Laboratory.

Gerczak, T.J., J.D. Hunn, R.A. Lowden, T.R. Allen. 2016. "SiC Layer Microstructure in AGR-1 and AGR-2 TRISO Fuel Particles and the Influence of Its Variation on the Effective Diffusion of Key Fission Products." J. Nucl. Mater. 480: 1-14.

Harp, J.M., P.A. Demkowicz, P.L. Winston, and J.W. Sterbentz. 2014. “An analysis of nuclear fuel burnup in the AGR-1 TRISO fuel experiment using gamma spectrometry, mass spectrometry, and computational simulation techniques." Nucl. Eng. Design 278: 395-405.

Harp, J.M., P.A. Demkowicz, and J.D. Stempien. 2016 "Fission Product Inventory and Burnup Evaluation of the AGR-2 Irradiation by Gamma Spectrometry", Paper HTR2016-18593. Proc. 8th International Topical Meeting on High Temperature Reactor Technology (HTR-2016), Las Vegas, Nevada, November 6-10, 2016. Also published in Nucl. Eng. Design 329: 134-141.

Hawkes, G.L. 2014. AGR-2 Daily As-Run Thermal Analyses. INL/ECAR-2476, Revision 1. Idaho Falls, Idaho: Idaho National Laboratory.

Hunn, J.D. and R.A. Lowden. 2006. Data Compilation for AGR-1 Variant 3 Coated Particle Composite LEU01-49T. ORNL/TM-2006/022, Revision 0. Oak Ridge, Tennessee: Oak Ridge National Laboratory.

Hunn, J.D. 2010. AGR-2 Fuel Compacts Information Summary: Prepared for the NRC MELCOR Project. ORNL/TM-2010/296, Revision 1. Oak Ridge, Tennessee: Oak Ridge National Laboratory.

Hunn, J.D., F.C. Montgomery, and P.J. Pappano. 2010a. Data Compilation for AGR-2 UCO Variant Compact Lot LEU09-OP2-Z. ORNL/TM-2010/017, Revision 1. Oak Ridge, Tennessee: Oak Ridge National Laboratory.

Hunn, J.D., F.C. Montgomery, and P.J. Pappano. 2010b. Data Compilation for AGR-2 $\mathrm{UO}_{2}$ Compact Lot LEU1 1-OP2-Z. ORNL/TM-2010/055, Revision 1. Oak Ridge, Tennessee: Oak Ridge National Laboratory.

Hunn, J.D., T.W. Savage, and C.M. Silva. 2010. AGR-2 Fuel Compact Pre-Irradiation Characterization Summary Report. ORNL/TM-2010/226, Revision 0. Oak Ridge, Tennessee: Oak Ridge National Laboratory.

Hunn, J.D., T.W. Savage, and C.M. Silva. 2012. AGR-1 Fuel Compact Pre-Irradiation Characterization Summary Report. ORNL/TM-2012/295, Revision 0. Oak Ridge, Tennessee: Oak Ridge National Laboratory.

Hunn, J.D., R.N. Morris, C.A. Baldwin, F.C. Montgomery, and C.M. Silva. 2012. PIE on Five Irradiated AGR-1 Compacts. ORNL/LTR-2012/397, Revision 0. Oak Ridge, Tennessee: Oak Ridge National Laboratory. 
Hunn, J.D., R.N. Morris, C.A. Baldwin, F.C. Montgomery, C.M. Silva, and T.J. Gerczak. 2013a. AGR-1 Irradiated Compact 4-4-2 PIE Report. ORNL/TM-2013/236, Revision 0. Oak Ridge, Tennessee: Oak Ridge National Laboratory.

Hunn, J.D., C.A. Baldwin, T J. Gerczak, F.C. Montgomery, R.N. Morris, C.M. Silva, P.A. Demkowicz, Hunn, J.D., R.N. Morris, C.A. Baldwin, F.C. Montgomery, C.M. Silva, and T.J. Gerczak. 2013b. PIE on Three Irradiated AGR-1 Compacts in FY13. ORNL/LTR-2013/291, Revision 0. Oak Ridge, Tennessee: Oak Ridge National Laboratory.

Hunn, J.D., C.A. Baldwin, T.J. Gerczak, F.C. Montgomery, R.N. Morris, and C.M. Silva. 2014a. AGR-1 Irradiated Compacts 5-2-3 and 5-2-1 PIE Report: Evaluation of As-Irradiated Fuel Performance with Leach Burn Leach, IMGA, Materialography, and X-ray Tomography. ORNL/TM-2014/171, Revision 0. Oak Ridge, Tennessee: Oak Ridge National Laboratory.

Hunn, J.D., R.N. Morris, C.A. Baldwin, F.C. Montgomery, and T.J. Gerczak. 2014b. PIE on Safety Tested AGR-1 Compacts 5-3-3, 5-1-3, and 3-2-3. ORNL/TM-2014/484, Revision 0. Oak Ridge, Tennessee: Oak Ridge National Laboratory.

Hunn, J.D., R.N. Morris, C.A. Baldwin, F.C. Montgomery, and T.J. Gerczak. 2014c. PIE on Safety-tested AGR-1 Compacts 4-1-2 and 4-4-3. ORNL/LTR-2014/101, Revision 0. Oak Ridge, Tennessee: Oak Ridge National Laboratory.

Hunn, J.D., C.A. Baldwin, T J. Gerczak, F.C. Montgomery, R.N. Morris, C.M. Silva, P.A. Demkowicz, J.M. Harp, S.A. Ploger, I.J. van Rooyen, and K.E. Wright. 2014d. "Detection and Analysis of Particles with Failed SiC in AGR-1 Fuel Compacts." Paper HTR2014-31254 in Proceedings of the HTR 2014, Weihai, China, October 27-31, 2014. Also published in Nucl. Eng. Design 360: 36-46.

Hunn, J.D., R.N. Morris, C.A. Baldwin, and F.C. Montgomery. 2016. Safety Testing of AGR-2 UCO Compacts 5-2-2, 2-2-2, and 5-4-1. ORNL/TM-2016/423, Revision 0. Oak Ridge, Tennessee: Oak Ridge National Laboratory.

Lowden, R.A. 2006. Fabrication of Baseline and Variant Particle Fuel for AGR-1. ORNL/CF-2006/02, Revision 0. Oak Ridge, Tennessee: Oak Ridge National Laboratory.

Phillips, J.A., C.M. Barnes, and J.D. Hunn. 2010. "Fabrication and Comparison of Fuels for Advanced Gas Reactor Irradiation Tests." Paper HTR2010-236 in Proceedings of the 5th International Topical Meeting on High Temperature Reactor Technology, HTR 2010, Prague, Czech Republic, October 18 20, 2010.

Sterbentz, J.W. 2014. JMOCUP As-Run Daily Depletion Calculation for the AGR-2 Experiment in the ATR B-12 Position. ECAR-2066, Revision 2. Idaho Falls, Idaho: Idaho National Laboratory.

van Rooyen, I.J., D.E. Janney, B.D. Miller, P.A. Demkowicz, and J. Riesterer. 2014. "Electron Microscopic Evaluation and Fission Product Identification of Irradiated TRISO Coated Particles from the AGR-1 Experiment, A Preliminary Review." Nucl. Eng. Design 271: 114-122. 